\title{
The 37-year dynamics of a subalpine passerine bird community, with special emphasis on the influence of environmental temperature and Epirrita autumnata cycles
}

\author{
Småfågelsamhällets sammansättning och beståndsväxlingar under 37 år i ett område \\ fjällbjörkskog $i$ Lappland, med särskild hänsyn till inverkan av temperaturen och \\ förekomsten av fjällbjörkmätarlarver
}

ANDERS ENEMAR, BENGT SJÖSTRAND, GÖRAN ANDERSSON \& TED VON PROSCHWITZ

\begin{abstract}
The breeding passerine bird community of $9 \mathrm{~km}^{2}$ of a primeval subalpine birch forest in Swedish Lapland was censused yearly from 1963 through 1999. The community density remained stable, fluctuating around a mean value of $403 \pm 85$ territories $/ \mathrm{km}^{2}$. Species richness increased by an average of one species every four years. Twenty species made up $98 \%$ of the community and Phylloscopus trochilus (40\%) and Fringilla montifringilla (19\%) remained the dominant species. The species turnover rate between successive seasons was on average $30 \%$. The mean temperatures in June and July were positively correlated to the community density two years and one year later, respectively, less so for the densities of the individual species. Fringilla montifringilla increased in density during the first two years of each Epirrita autumnata caterpillar

outbreak, whereas the other species responded only weakly or not at all. All species tended to fluctuate in parallel (no significant opposite trends) which together with the other results suggests that the investigated bird community is far from saturated.

Anders Enemar, Department of Zoology, University of Göteborg, Box 463, SE-405 30 Göteborg, Sweden.

E-mail: a-enemar@hem.utfors.se

Bengt Sjöstrand, Gunnesbo 120, SE-450 34 Fiskebäckskil, Sweden

Göran Andersson, Ted von Proschwitz, Göteborgs Naturhistoriska Museum (Natural History Museum Göteborg), Box 7283, SE-402 35 Göteborg, Sweden.
\end{abstract}

Received 10 November 2003, Accepted 14 June 2004, Editor: Å. Lindström

\section{Contents}

64
64
66
68
68
68
70
70
70
70
70
71
74
74
74
75
75
75
76
76

Introduction

Introductory statements

The study area

Methods

The bird census

Calculating the density index of the bird species

The insect census

Environmental temperature

Statistics

Census material quality

Birds

Insects

Census results

The composition and density of the bird fauna

Epirrita autumnata dynamics

Environmental temperature

Analyses and discussion

The composition of the passerine bird community

Number of species

Species turnover
The density fluctuations of the total community The influence of environmental temperature on the total community

Fluctuations in the species populations

Environmental temperature and species density fluctuations

Influence of the Epirrita autumnata outbreaks

The relations between the density fluctuations of the species

Fluctuations of the short-distance versus longdistance (tropical) migrants

Long-term trends versus short-term fluctuations Examples of strengths and weaknesses of longterm bird census work

Concluding hypothesis: Why does the rich subalpine birch forest remain unsaturated?

Acknowledgements

References

Sammanfattning

Appendices 


\section{Introduction}

Having analysed the classical census works by e.g. Palmgren (1930) and Merikallio (1946) and having observed the appearance of more efficient census methods, Lauri Siivonen (1948) pointed to the possibility of designing investigations to follow shortterm fluctuations in passerine bird populations. At that time the censuses had mainly aimed at describing the composition of the bird communities and the regional distribution of the species populations. Thereafter population fluctuation studies soon developed into one of the main streams in the field investigations on birds, although some initiatives had been taken place at a much earlier stage (Kendeigh 1982). This highlighted the need for long-term investigations aimed at discovering long-term trends in bird densities, which would also provide sufficient data that might help to identify communitycontrolling factors. The latter expectation has been only partly fulfilled and the interpretations are controversial. After reviewing the field, Wiens (1989a, b) recommended to continue to examine how communities vary in nature by approaching the patterns of variation as something of interest in their own right. From the outset this has constituted the guideline for our project, which has provided a great deal of descriptive information regarding the bird fauna in the subalpine birch forests in Swedish Lapland. The density figures for the passerine populations over the first 37 years (1963-1999) are presented and analysed from selected aspects in this report.

Long-term bird census studies are not easy. Only a few have been published that were carried out over a period of at least 20 years without interruptions and that cover study areas of about one square kilometre or more, using tested census techniques. Apart from the earlier reports based on the first 20 years of our project (Enemar et al. 1984, Svensson et al. 1984), two long-term census investigations which meet the above-mentioned requirements have been carried out in deciduous forests. They are a 20-year study (1975-1994) in Bialowieza National Park (BNP) in Poland (Wesolowski \& Tomialojc 1997) extended by five years by Wesolowski et al. (2002), and a 30-year census (1969-1998), albeit in a rather small study plot, in the Hubbard Brook Experimental Area, New Hampshire, USA (Holmes \& Sherry 2001).

It is well known that the weather conditions are rather unpredictable in the far north and that they may shift dramatically within as well as between seasons. One weather factor, the environmental temperature, has been chosen and related to the dynamics of the bird community and of individual species. A regularly occurring dramatic event in the study area is the cyclic appearance of masses of the lepidopteran caterpillars Epirrita autumnata, which creates a superabundant food situation at approximately ten-year intervals (Selås et al. 2001). Thus, a census of birds as well as of the caterpillars must extend over several decades in order to permit a reliable analysis of the effect of the outbreaks on the community density.

\section{Introductory statements}

A long-term bird census investigation is a formidable undertaking, involving a great deal of intrinsic problems that have been identified and discussed for many years, regarding e.g. use of concepts, choice of space and time scaling of the field work, in addition to the special problems of long-term project funding. The situation of our investigation in relation to these matters is described below as a background to the subsequent descriptions and discussions.

1) The community concept has long been controversial. Wiens (1980) presented a summary of factors that make the concept hazardous to use. He concluded that it is difficult to establish that communities (e.g. passerine bird communities) exist in any functional sense, as they are represented by a number of independent or interacting species populations within a selected area or habitat of varying size and over varying lengths of time. Newton (1998) and other reviewers support this opinion. Underwood (1986) argued that communities are not readily identifiable in nature and that the tendency is to replace the term "community" with "assembly". However, McIntosh (1995) found that " the recent work perpetuates the original dichotomy between integrated community concept and individualistic non-integrated concept". Due to the confusion of diverse opinions, we wish to stress that we use the term community to refer to the bird populations in our study area without considering to whether or not they represent a functional entity.

2) The need for long-term bird census work has been stressed for many years (e.g. Wiens 1977, 1984, Järvinen 1980). Franklin (1989) listed the reasons in detail. The unavoidable question about how long a long-term study should be has also been put forward. A number of suggestions have been made, based on e.g. the average life-span of the birds, cyclic processes in the habitat, and identification and frequency of unusual events (Wiens 1977, Calder III 1984, Noon 


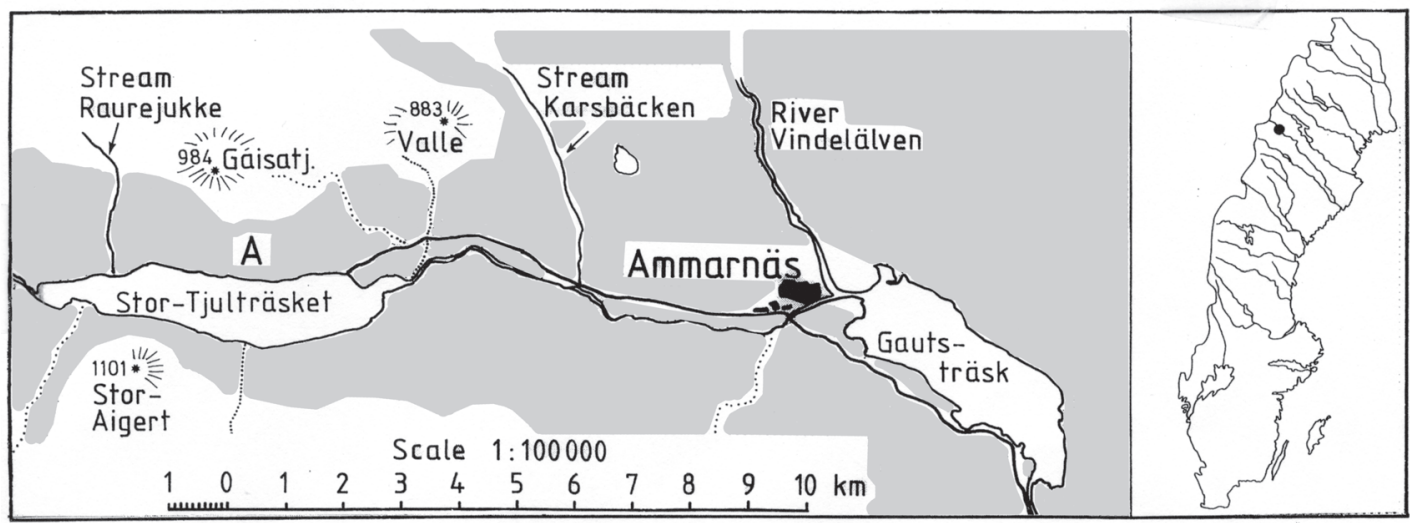

Figure 1. Map of the Ammarnäs area of Swedish Lapland. Its location in Sweden is indicated by the solid circle on the inserted map. "Asterisks" denote mountain peaks and adjacent figures are their heights in metres a.s.l. Wooded areas are stippled and tracks are marked by dotted lines. The letter A indicates the position of the study area. It is delimited in the south by Lake StorTjulträsket and the road between this lake and the village of Ammarnäs, in the west by the Raurejukke Stream and in the east by the Karsbäcken Stream.

Karta över Ammarnäs-området i södra Lappland. Läget är utmärkt med en prick på den infällda Sverige-kartan. Närliggande fjälltoppar är markerade med stjärnor och siffrorna bredvid anger höjden över havet. Fjällskogarnas utsträckning markeras med prickade områden. Det inventerade området (A) begränsas i söder av Stor-Tjulträsket och vägen mellan denna sjö och Ammarnäs by, $i$ väster av jokken Raurejukke och i öster av Karsbäcken.

et al. 1985, Wiens et al. 1986, Weatherhead 1986). We believe that our 37-year census period is long enough to avoid the most obvious risks of data distortion and misinterpretations, even when taking into account the 10 to 11 -year cycles of the lepidopteran caterpillar outbreaks. Several of our analyses were carried out for periods of different length in order to illustrate the effect of varying temporal scales of investigation.
3) The study area is large enough $\left(9 \mathrm{~km}^{2}\right)$ to permit a fairly safe characterisation of the yearly density and composition of the bird fauna of the subalpine birch forest (cf. Wiens 1981).

4) The birch forest is almost exclusively primeval. This is an advantage because the effect of continuous habitat change can be more or less excluded as a factor to be considered in the interpretations and analyses. Our study area shares its primeval state

Figure 2. A glade in the rich mountain birch forest of the study area, showing the characteristic luxuriant undergrowth of herbs. Late June 2004. Photo G. Andersson. En glänta i fältarbetsområdets rika fjällbjörkskog ("ängsbjörkskog") med den karakteristiska frodiga örtvegetationen. Sent i juni 2004. Foto G. Andersson.

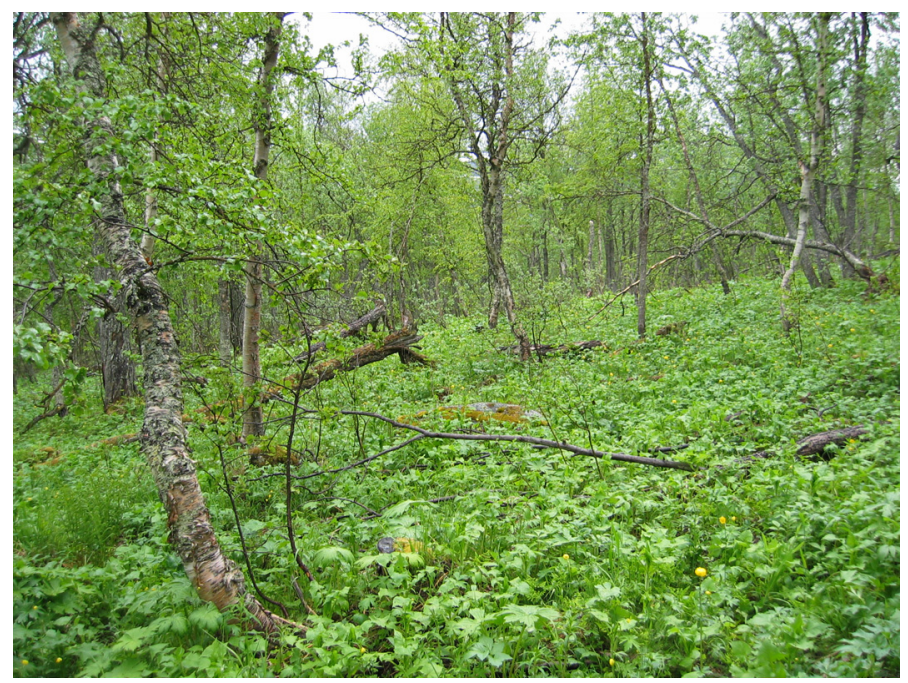




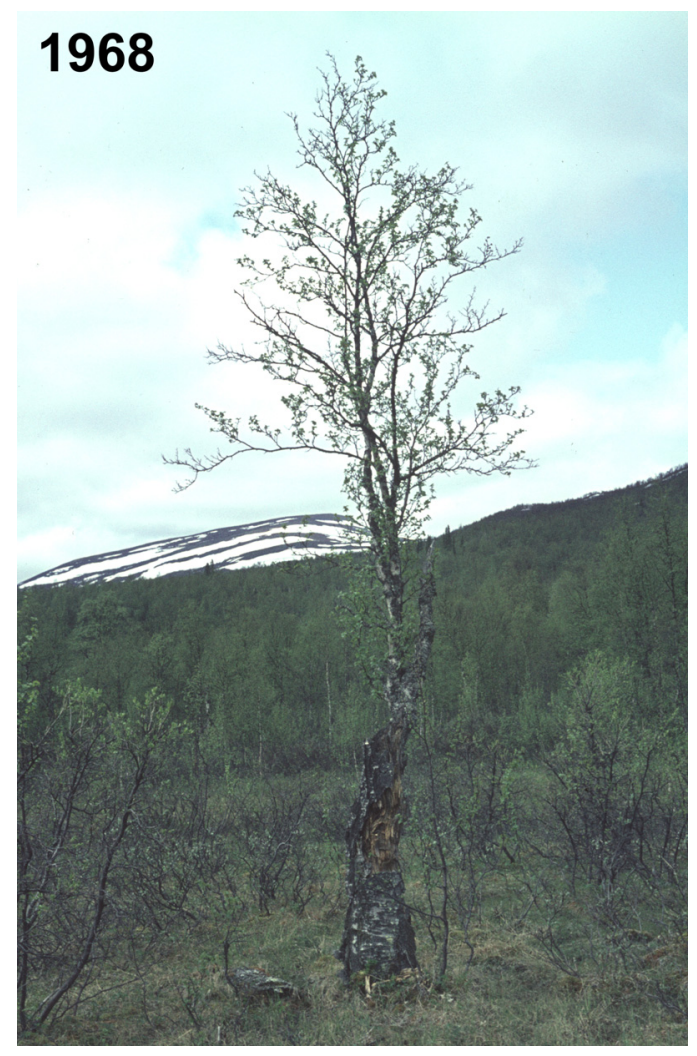

with the census plots in the above-mentioned BNP.

5) Several authors have mentioned the problem of funding long-term census investigations. This problem is caused, among other things, by the fact that planned dissertation projects at universities should not take longer than about four years and that the sponsors favour projects that have the potential to deliver valuable results within a relatively short time. By necessity, therefore, the present census in the subalpine birch forests is part of a long-term project (the LUVRE-project) that has no permanent or formal connection to any university department, i.e. it is free from imperative directives to adapt to current research trends and from demands for frequent production of high quality publications. This longterm, continuous investigation has been, and still is, exclusively based on the dedicated interest and curiosity of staff members, amateurs and university people alike, who for the most part participate despite only meagre financial compensation, if any, for their travel and living expenses related to their field work. The theme of the project has been and still is: A series

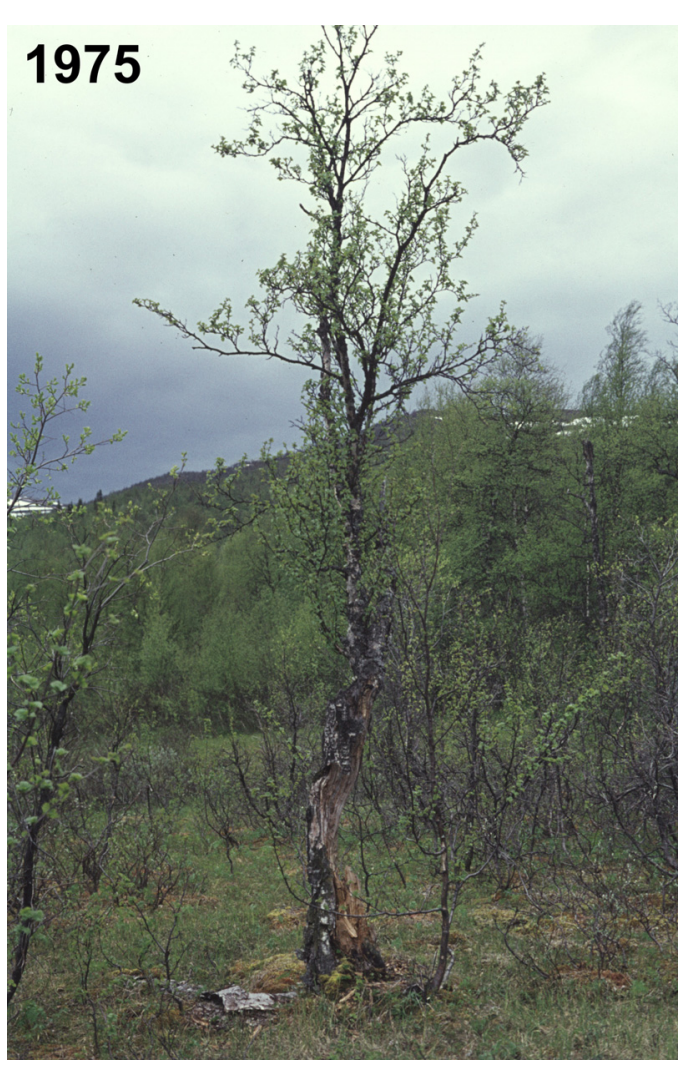

of biological annual censuses never reaches the point that justifies its cessation.

\section{The study area}

The study area covers $9 \mathrm{~km}^{2}$ of mountain birch forest on the south-facing slopes of the Gaisatj (Kaissats) and Valle mountains near the small village of Ammarnäs in Swedish Lapland. It extends from the Raurejukke stream in the west to the Karsbäcken stream in the east and its southern border consists of Lake Stor-Tjulträsket and the road from this lake to Ammarnäs (Figure 1). The approximate position of the investigated area is $65^{\circ} 58^{\prime}-65^{\circ} 59^{\prime} \mathrm{N}, 15^{\circ} 58^{\prime}-$ $16^{\circ} 8^{\prime} \mathrm{E}, 540$ to 720 m.a.s.1.

The birch forest is predominantly of the rich type ("meadow birch forest") with luxuriant undergrowth of herbs (Figure 2). It gradually turns into the dry heath type on the upper slopes as well as on the top of hillocks and ridges at lower levels (Figure 3). A few small clearings near the settlements in the southeast and around a small deserted cottage in the 

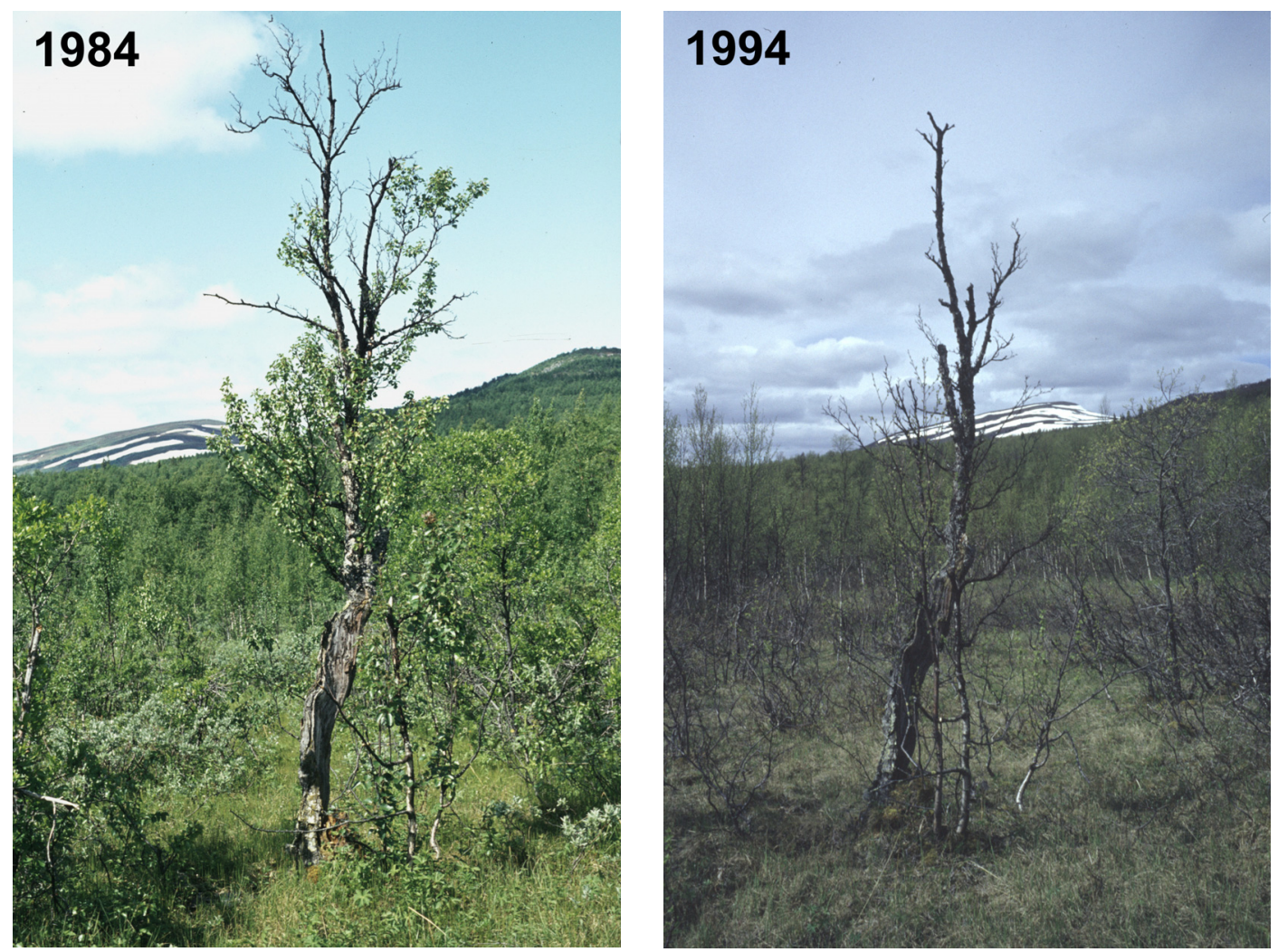

Figure 3. A swampy part of the birch forest in one of the study plots, presented with one photo from each of the four decades of the project period. The habitat resembles that of the birch forest of the heath type. The single birch, hurt but tenacious of life, and the remote and partly snow-covered peak of the mountain Gaisatj have served as "landmarks" for the photographer. The photos indicate that the main structure of the habitat did not change significantly over the decades. All photos were taken in June, unfortunately at different leafing stages of the forest. The actual years are denoted on the pictures. Photo G. Andersson.

En moss-artad del av björkskogen i en av provytorna, presenterad med ett fotografi från vart och ett av projektets fyra decennier. Biotopen är här ett mellanting mellan ängsbjörkskog och hedbjörkskog. Den ensamma björken, skadad men seglivad, och den delvis snötäckta toppen av fjället Gaisatj i fjärran har tjänat som riktmärken vid fotograferingen. Bilderna ger intrycket att biotopen inte förändrats $i$ någon betydande grad under decenniernas lopp. Alla fotografierna är tagna i juni, tyvärr vid olika stadier av lövsprickningen. De aktuella årtalen är angivna på bilderna. Foto G. Andersson.

central part of the area have been invaded by growing birch thickets, and only insignificant tree felling for firewood has occurred during the period. Scattered small bogs are also found within the area. On the whole the forest can be considered primeval and partly consists of tall birches of considerable age. New birches sprout where old trees have fallen. Spontaneous thinning of the forest into dwarf-shrub heath due to habitat transformation (Kullman 1981) has not been observed, and the Epirrita caterpillar outbreaks have only killed a few scattered birches locally. Taken as a whole, therefore, the impression is that the habitat of the investigated area has remained constant throughout the 37-year study period, showing no radical transformation of any kind (Figure 3).

The study area has of course been exposed to diffuse and indirect effects of human activities, such as acidified precipitation, which may cause slow and easily over-looked changes in the habitat quality. In fact, egg shell defects and abnormally small clutches have appeared in the nests of a number of small passerines, apparently induced by air-pollution (Nyholm 1981). As this disturbance is mainly confined to the birds breeding within $100 \mathrm{~m}$ of the shore-line of the lake Stor-Tjulträsket, it is considered 
to have only an insignificant effect on the bird community dynamics as a whole.

\section{Methods}

\section{The bird census}

The bird census work started in 1963 and has continued without interruption ever since, for two to three weeks in June during the breeding season. Two methods have been applied: 1) territorial mapping in restricted study plots of known size, and 2) line transects traversing the whole study area. The scope of the fieldwork as well as information about the census-takers can be seen in Tables 1-3.

The mapping and evaluation of territory densities were carried out in accordance with international recommendations (Anon. 1970). Most passerine species in the birch forest establish more or less distinct territories that usually appear as observation clusters on the species maps. A borderline case is the, at times, semi-colonial Carduelis flammea, which moves around calling and singing over at wide area even during the breeding season. However, mapping the alighting positions after the song-flights combined with other breeding indications have provided interpretable species maps. The Turdus species, especially the colonial ones, are more difficult to map and have therefore been censused by nest counts.

Line transecting means that the observer walks along tracks running all over the $9 \mathrm{~km}^{2}$ of the study area, noting all birds heard or seen, predominantly singing males, which might indicate the presence of a territory. The unlimited distance recording technique has been adopted, as it is next to impossible to estimate the location of and distance from a bird that is heard but not seen (cf. the IPA-method worked out by Blondel et al. (1981)). The tracks used have differed over years although the majority have been followed every season. As the size of the area covered by the observer is unknown, the line transect data are only used to calculate the relative abundance of the

Table 1 . The study plots $1963-1999$.

Provytor, storlek och inventeringsair.

\begin{tabular}{ccc}
\hline $\begin{array}{l}\text { Study plot } \\
\text { Provyta }\end{array}$ & $\begin{array}{l}\text { Size, } \mathrm{km}^{2} \\
\text { Storlek }\end{array}$ & $\begin{array}{l}\text { Census period } \\
\text { Inventeringsperiod }\end{array}$ \\
\hline A4 & 0.129 & $1963-1999$ \\
A5 & 0.111 & $1963-1999$ \\
A6 & 0.122 & $1963-1972$ \\
A7 & 0.080 & $1964-1972$ \\
A8 & 0.080 & $1966-1999$ \\
A9 & 0.100 & $1972-1999$ \\
\hline
\end{tabular}

species, i.e. their proportion of the total number of observations. It is extremely important that the fieldwork of each census-taker is strictly standardised. A total number of at least 1500 observations is required to record the fluctuations of the sparsely occurring species (down to a relative abundance of about 2\%, Enemar \& Sjöstrand 1967). On average, this means a total of about 30 hours of transect work carried out along an $80-\mathrm{km}$ track. The minimum number of observations was not achieved in the first two seasons.

\section{Calculating the density index of the bird species}

The data from the study plots provide a fairly reliable information about the density change between years of the total bird community and of the populations of the most abundant species. The yearly fluctuations in the plots are in reasonable accordance with those of the total study area (Enemar \& Sjöstrand 1970). However, this does not apply to the majority of the species, because they are too few in numbers in relation to the total size of the mapped study plots. Due to chance, the density figures of these sparsely occurring species may deviate significantly from those of the larger study area (cf. Rotenberry \& Wiens' (1980) "checkerboard effect"). Much larger study plots should be mapped so as to avoid this "sampling error". This is not possible for practical reasons, such as the fact that the mapping is a highly time-consuming work (the plots must be mapped ten times each season). As the main aim of this investigation has been to record the dynamics of the species populations, the problem of the rare species has been solved, at least to some extent, by using the relative abundance data from the line transects. However, these figures are of no use on their own, as they depend not only on the density change of the actual species but also on that of all other species in the community. Therefore they have been combined with the density of the bird community as obtained from the study plots, resulting in a so-called derived density index for each species. This index was introduced by Enemar \& Sjöstrand (1970), who developed and improved a similar census method invented and applied in the same habitat many years ago by Klinckowström(1909). The index is calculated as follows:

$$
D D=n D_{R} / R
$$

where $D D$ is the derived density index, $n$ is the number of observations of a species during the line 
Table 2. Census-takers and size of mapped areas 1963-1999. (AE=Anders Enemar, AH=Alexander Hellquist, AdJ=Adjan de Jong, BS=Bengt Sjöstrand, EN=Erik Nyholm, GP=Göran Paulson, HJ=Håkan Jansson, HM=Harry Myhrberg, HN=Hans Nyström, IL=Ingvar Lennerstedt, JoG=Jonas Grahn, JöG=Jörgen Grahn, LN=Lars Nilsson, $\mathrm{L} \AA \mathrm{F}=$ Lars-Åke Flodin, $\mathrm{MdB}=$ Marian de Boom, $\mathrm{TJ}=$ Tore Johansson.)

Inventeringsår, provytornas sammanlagda storlek och tjänstgörande inventerare.

\begin{tabular}{llllll}
\hline $\begin{array}{l}\text { Year } \\
\text { Ar }\end{array}$ & $\begin{array}{l}\text { Area, } \mathrm{km}^{2} \\
\text { Storlek }\end{array}$ & $\begin{array}{l}\text { Census-taker } \\
\text { Inventerare }\end{array}$ & $\begin{array}{l}\text { Year } \\
\text { Ar }\end{array}$ & $\begin{array}{l}\text { Area, km } \\
\text { Storlek }\end{array}$ & $\begin{array}{l}\text { Census-taker } \\
\text { Inventerare }\end{array}$ \\
\hline 1963 & 0.362 & AE, BS, HM & 1982 & 0.420 & LN \\
1964 & 0.442 & AE, BS, IL & 1983 & 0.420 & LN \\
1965 & 0.442 & AE, BS, IL & 1984 & 0.420 & AE, MdB \\
1966 & 0.522 & AE, BS, IL & 1985 & 0.420 & AE, MdB \\
1967 & 0.522 & AE, BS, IL & 1986 & 0.420 & AE, MdB \\
1968 & 0.522 & AE, BS, IL & 1987 & 0.420 & AE, MdB \\
1969 & 0.522 & AE, BS, IL & 1988 & 0.420 & AE, MdB \\
1970 & 0.522 & AE, BS, IL & 1989 & 0.420 & AE, MdB \\
1971 & 0.522 & AE, BS, EN, HM & 1990 & 0.420 & AdJ, MdB \\
1972 & 0.622 & AE, BS, IL & 1991 & 0.420 & AdJ, MdB \\
1973 & 0.420 & AE, IL & 1992 & 0.420 & AdJ, MdB \\
1974 & 0.420 & AE, IL & 1993 & 0.420 & HN, JoG, JöG \\
1975 & 0.420 & AE, IL & 1994 & 0.420 & HN, GP, HJ \\
1976 & 0.420 & IL, LN & 1995 & 0.420 & HN, GP, HJ \\
1977 & 0.420 & IL, LN & 1996 & 0.420 & HN, GP, HJ \\
1978 & 0.420 & IL, LN & 1997 & 0.420 & HN, GP, TJ \\
1979 & 0.420 & LN & 1998 & 0.420 & GP, HJ, TJ \\
1980 & 0.420 & LN & 1999 & 0.420 & GP, AH \\
1981 & 0.420 & LN & & & \\
\hline
\end{tabular}

Table 3. Total number of line transect observations and census-takers from 1963-1999.

The names of the census-takers are given in full in Table 2.

Arr, antal registreringar och inventerare för linjetaxeringarna åren 1963-1999.

Initialerna är förklarade $i$ Tabell 2.

\begin{tabular}{llllll}
\hline $\begin{array}{l}\text { Year } \\
\text { Ar }\end{array}$ & $\begin{array}{l}\text { Observations } \\
\text { Registreringar }\end{array}$ & $\begin{array}{l}\text { Census-taker } \\
\text { Inventerare }\end{array}$ & $\begin{array}{l}\text { Year } \\
A r\end{array}$ & $\begin{array}{l}\text { Observations } \\
\text { Registreringar }\end{array}$ & $\begin{array}{l}\text { Census-taker } \\
\text { Inventerare }\end{array}$ \\
\hline 1963 & 809 & AE & 1982 & 3282 & AE, LN \\
1964 & 1077 & AE & 1983 & 3112 & AE, LN \\
1965 & 4129 & AE, BS & 1984 & 3488 & AE, MdB \\
1966 & 3052 & AE, BS & 1985 & 3790 & AE, MdB \\
1967 & 3036 & AE, BS & 1986 & 3744 & AE, HN \\
1968 & 3037 & AE, BS & 1987 & 3586 & AE, HN \\
1969 & 3057 & AE, BS & 1988 & 3661 & HN, MdB \\
1970 & 3061 & AE, BS & 1989 & 3983 & HN, MdB \\
1971 & 3115 & AE, BS & 1990 & 3647 & HN, AdJ \\
1972 & 3110 & AE, BS & 1991 & 2489 & HN, AdJ \\
1973 & 3233 & AE, BS & 1992 & 3589 & HN, AdJ \\
1974 & 3729 & AE, BS & 1993 & 4176 & HN, JoG, JöG \\
1975 & 1561 & AE & 1994 & 3846 & HN, GP, HJ \\
1976 & 3025 & AE, LN & 1995 & 3186 & HN, GP, HJ \\
1977 & 2506 & AE, LN, LÅF & 1996 & 3360 & HN, GP, TJ \\
1978 & 3030 & AE, LN & 1997 & 3053 & GP, HJ, TJ \\
1979 & 3054 & AE, LN & 1998 & 2991 & GP, HN \\
1980 & 2416 & AE, LN & 1999 & 1621 & \\
1981 & 2735 & AE, LN & & &
\end{tabular}


transects, $D_{R}$ is the density reference, which is the total study plot density of the passerine species except Corvidae and the thrushes. Corvidae were excluded because they could not be mapped in a reliable way. They are few. Nesting Corvus corone was established in the study plots only twice during the 37-year period. The thrushes were excluded because of their tendency to breed in colonies, which may seriously bias the dynamics of the study plot density compared to that of the total study area. $R$ is the total number of observations of the species included in $D_{R}$.

\section{The insect census}

The annual insect census, which commenced in 1967, has been strictly standardised (Andersson \& Jonasson 1980). The relative abundance of insects on the birches has been estimated in three permanent plots, $50 \times 50 \mathrm{~m}$ in size, located on the south-facing slopes of the Gaisatj and Valle mountains. The fieldwork began when the birch leaves were new, normally during the third week of June, and continued for about two weeks. Each plot was investigated six times by examining, on each occasion, 1000 short shoots and counting all insects, spiders and mites. No specimens were collected, which means that they were only ranged under a group (individual species not identified). An exception was the geometrid moth Epirrita autumnata, which was dealt with separately. The relative abundance is expressed as the mean number of animals per 1000 short shoots.

\section{Environmental temperature}

The daily temperature of the Ammarnäs area has been measured mostly on a local basis. Where local measurements are lacking, the temperature data have been interpolated from the registrations of neighbouring weather stations.

\section{Statistics}

Most of the calculations are based on time series, which means that the population numbers are not independent because the population size in any given year is partly dependent on the number of birds present during the preceding season. Correlation and regression tests have nevertheless been applied to the figure data mainly because they are an efficient and straightforward way to present condensed information about the dynamic processes that have occurred in the study area. Strictly speaking, this means that the routinely presented levels of probability are not always reliable. The statistical tests used are all two-tailed: two-sample t-tests, $\mathrm{X}^{2}$ test, correlation and regression, mainly in line with Bonnier \& Tedin (1940).

\section{Census material quality}

Birds

As stressed by Wiens (1989a), it is of utmost importance that the methods applied in bird census investigations are clearly defined and that the source of any errors are identified and evaluated. A particular problem related to long-term projects is that changes of census-takers are unavoidable in the long run. This means the introduction of a personal margin of error, which cannot be fully eliminated no matter how well trained or how faithful to the standardised census technique a new census-taker is. Therefore three experiments have been performed in the actual birch forests to investigate these and related problems.

1. As the derived density index is the main parameter used in this study, it is of interest to know to what degree the mapping censuses capture the total number of territories within the plots. When the territories were represented by identified nests they exceeded the mapped territories by only $4.5 \%$, although there were clear species differences (Enemar et al. 1976). Moreover, the number and positions of mapped territories accorded well with the actual number of territories of an abundant species, Phylloscopus trochilus, estimated with the aid of playback and colour ringing (Enemar et al. 1979). This indicates that the territory density, as obtained by mapping, is not very far from the real one in the plots and that it shows the direction of the yearly changes of the community density with reasonable reliability.

2. Four observers mapping the same study plot over two seasons obtained similar results, showing that one competent census-taker can replace another one, providing that the same procedure is strictly applied when evaluating the species maps (Enemar et al. 1978). Apparently, the quality differences that exist between even competent observers are largely eliminated due to the ten-fold reiteration of the mapping procedure in each plot.

3 . The proportional distribution of the species in the line transect samples may differ significantly between observers (Enemar \& Sjöstrand 1967). Obviously, this bias cannot be eliminated by taking larger line transect samples. Therefore comparisons between seasons in terms of the relative abundance 
Table 4. Census-takers and periods of insect investigation, 1967-1999.

$\mathrm{JJ}=\mathrm{Jan}$ Jonasson, GA = Göran Andersson, HR = Hans Ryberg, TvP = Ted von Proschwitz.

År, inventeringstid och insektsinventerare för de 33 åren 1967-1999.

\begin{tabular}{llllll}
\hline $\begin{array}{l}\text { Year } \\
\text { Ar }\end{array}$ & Period & $\begin{array}{l}\text { Census-taker } \\
\text { Inventerare }\end{array}$ & $\begin{array}{l}\text { Year } \\
\text { Ar }\end{array}$ & $\begin{array}{l}\text { Period } \\
\text { Tid }\end{array}$ & $\begin{array}{l}\text { Census-taker } \\
\text { Inventerare }\end{array}$ \\
\hline 1967 & 14-30 June & JJ & 1984 & 13-21 June & GA \\
1968 & 14-28 June & GA & 1985 & 14-24 June & TvP \\
1969 & 16-27 June & JJ, GA & 1986 & 16-25 June & GA \\
1970 & 15 June-3 July & HR & 1987 & 15-24 June & GA, TvP \\
1971 & 16 June-11 July & JJ, GA & 1988 & 19-28 June & GA \\
1972 & 17-30 June & JJ, GA & 1989 & 16-30 June & TvP \\
1973 & 19-28 June & JJ, GA & 1990 & 20-27 June & GA \\
1974 & 13-26 June & JJ, GA & 1991 & 20-29 June & TvP \\
1975 & 15-26 June & JJ, GA & 1992 & 13-22 June & GA \\
1976 & 17-28 June & JJ & 1993 & 20-28 June & TvP \\
1977 & 17-29 June & GA & 1994 & 17-29 June & GA \\
1978 & 18-29 June & GA & 1995 & 20-29 June & TvP \\
1979 & 15-27 June & GA & 1996 & 15-26 June & GA \\
1980 & 15-26 June & GA & 1997 & 19-26 June & TvP \\
1981 & 10-24 June & TvP & 1998 & 19-26 June & GA \\
1982 & 17-27 June & GA, TvP & 1999 & 23-29 June & TvP \\
1983 & 14-27 June & TvP & & & \\
\hline
\end{tabular}

values should be based on the field data of the same census-taker(s). To increase the chances of fulfilling this requirement, usually two observers worked on a complete transect every year (Table 3 ). The recorded relative abundance values have a certain bias because the species differ in conspicuousness. The deviations from the true values of the figures obtained during the line transect work are species specific as are the derived density indices.

Ficedula hypoleuca is abundant in the nest-boxes erected for experimental purposes within a small section of the study area. It has been included only in those line transects performed outside the nest-box areas.

In summary, the census work and the derived density index described above have only been applied in this investigation to obtain a fairly reliable registration of the fluctuation patterns of the species populations and the total community over quite large areas. It is absolutely essential to cover a study area of several square kilometres in size in habitats where the majority of the species are sparse, such as in the subalpine birch forest. The fluctuation pattern of the density indices of the species populations and the total community is mainly based on the information from the line transects, where non-territorial birds are counted together with the territorial ones in unknown proportions. The derived density figures will therefore differ from the study plot densities to a varying degree depending on e.g. the conspicuousness and general frequency of the species.

\section{Insects}

Only four persons have taken part in the insect census work since 1967 (Table 4). In 1969, the possible influence of personal factors on the census results was investigated and evaluated without finding any evidence of such influence (Andersson \& Jonasson 1980). Nor could any evidence of the

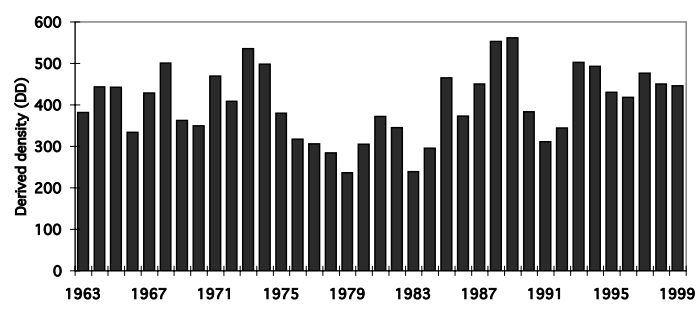

Figure 4. Derived densities of the passerine bird community in the study area 1963-1999. All species are included except for the corvids.

Variationen i småfågeltäthet (härledda tätheter) i studieområdet under perioden 1963-1999. Alla arter utom kråkfåglarna har tagits med. 

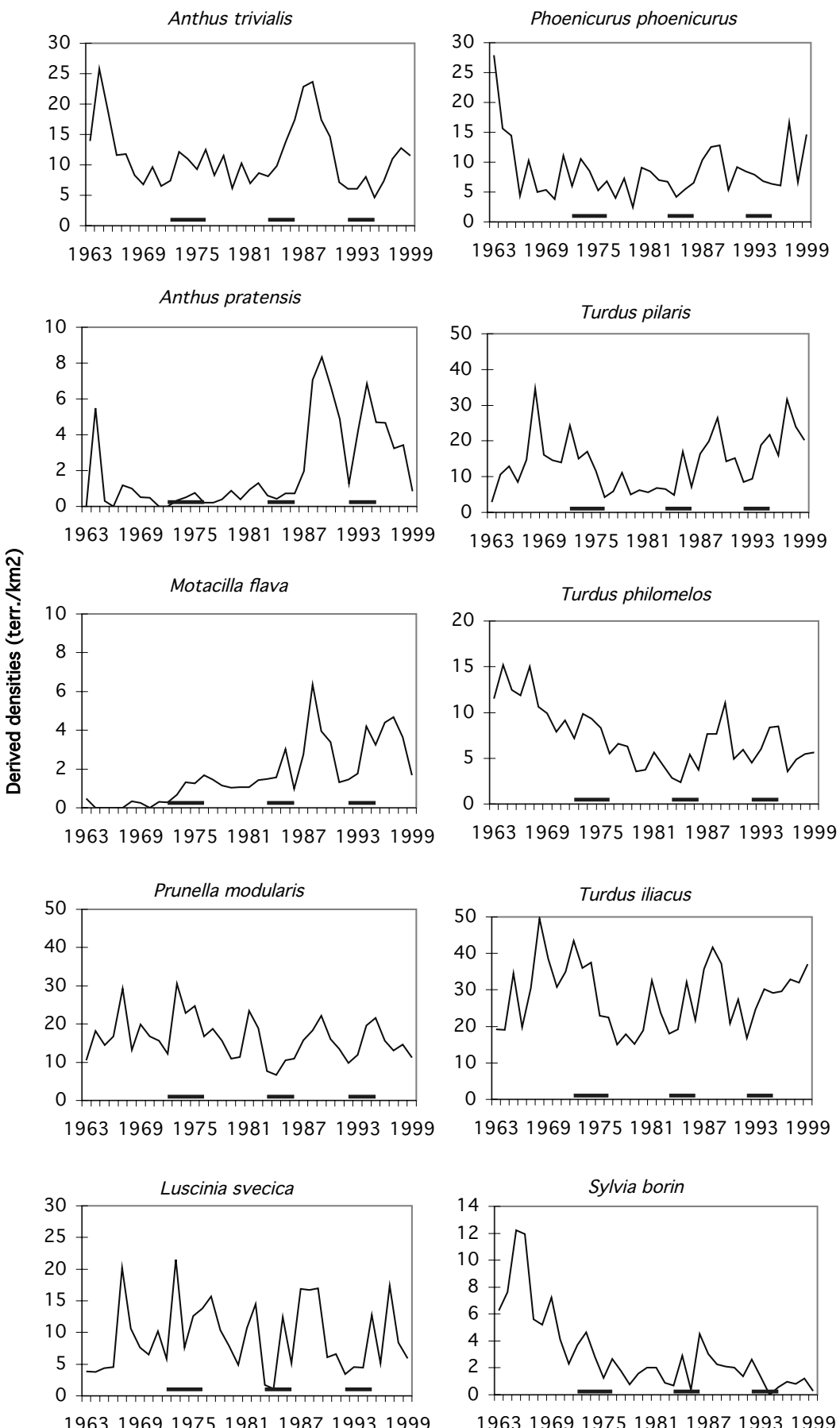

Figure 5. Derived densities of the 20 regularly occurring small passerine species in the study area. The broad horizontal lines indicate the periods of the three mass occurrences of Epirrita caterpillars (seasons with more than 10 caterpillars/1000 short birch shoots). 

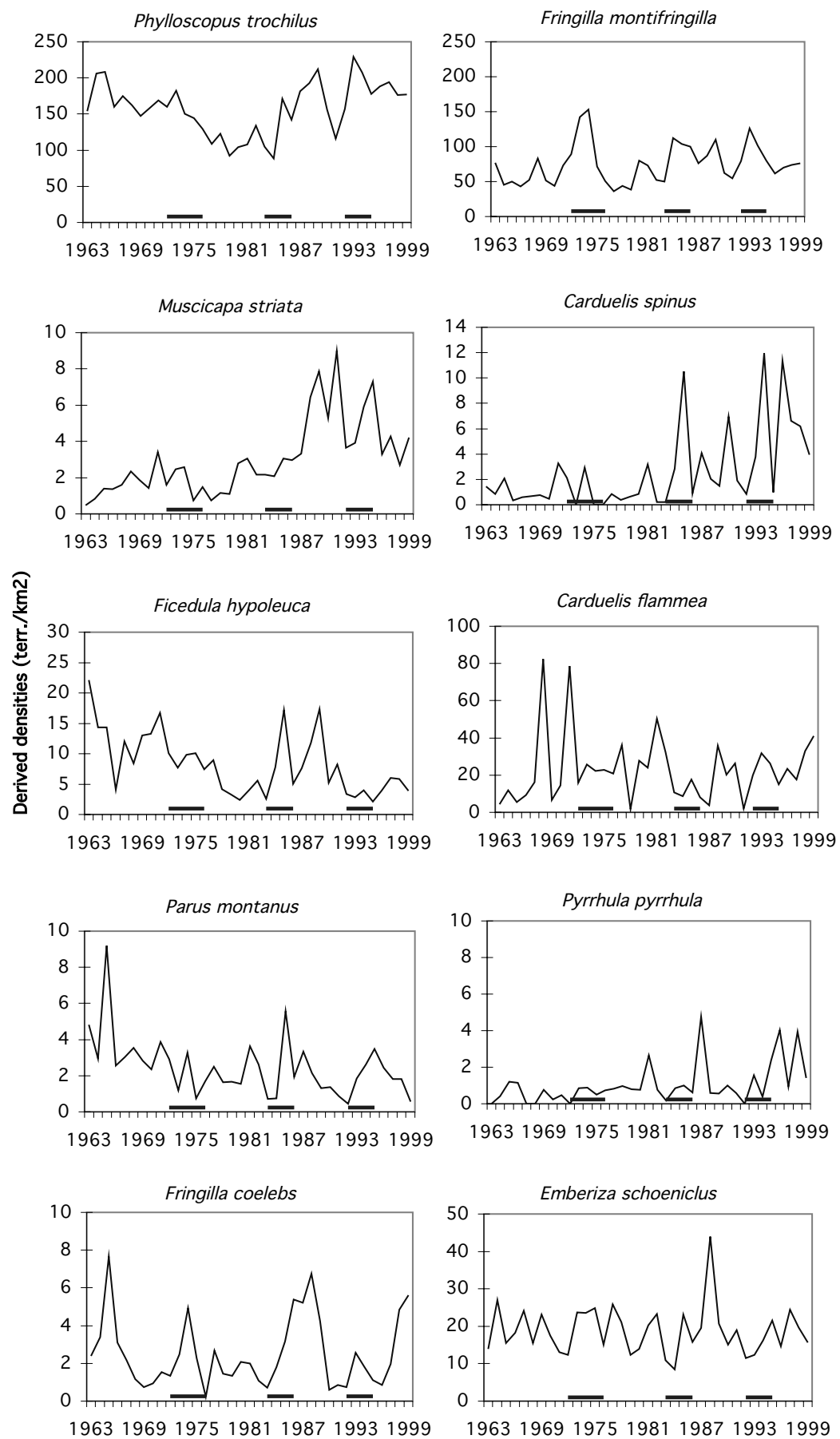

Kurvorna visar svängningar i beståndstätheten hos de 20 regelbundet häckande småfågelarterna i studieområdet. Siffrorna på den lodräta axeln anger de härledda tätheterna. De horisontella grova linjerna i diagrammen markerar årsföljder med massförekomst av björkmätarlarver (mer än 10 larver per 1000 kortskott på björkarna). 


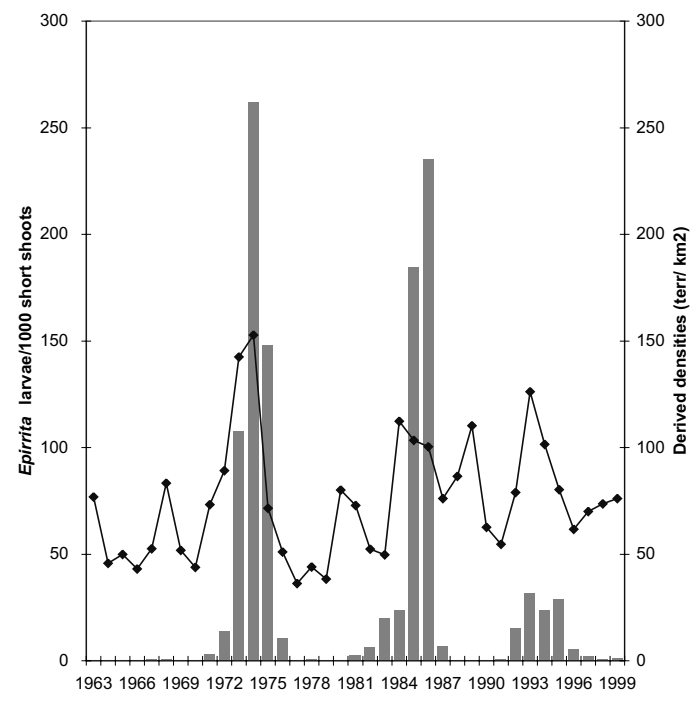

Figure 6. Density fluctuations of Fringilla montifringilla (curve with squares, right axis) and the Epirrita caterpillars (bars, left axis). Caterpillar counts started in 1967.

Kurvan visar förekomsten av bergfink perioden 1963-1999 (härledda tätheter, högra axeln). Staplarna visar antalet björkmätarlarver 1967-1999 (antal larver per tusen kortskott, vänstra axeln).

influences of ambient factors, such as temperature, cloud cover, precipitation, and/or wind, be found. The insect census was confined to birch branches no higher than $3 \mathrm{~m}$ above the ground. We do not know if the obtained values are representative of the upper level of the birches. We believe, however, that the figures are useful for the present investigation with regard to species that are strongly confined to the leaves, such as the Epirrita autumnata caterpillars.

\section{Census results}

The composition and density of the bird fauna

All bird species observed during the field work within the study area during the 37 years are listed in
Appendix 1 with information on number of seasons present. The densities of the passerine species (except Corvidae) as obtained by mapping or nest search in the study plots are shown in Appendix 2 for all 37 seasons. The yearly-derived densities are given in Appendix 3 for those passerine species (except Corvidae) that are confirmed or potential breeders in the birch forest.

The derived density values of the total passerine bird community (with Corvus corone and C. corax excluded, as they were not mapped) are presented for the 37 seasons in Figure 4.

Twenty-one passerine species have been documented as present in the study area during at least 32 of the 37 investigated seasons. The density fluctuations of 20 of these species are presented in Figure 5. One species, Parus major, has been excluded because its presence as breeder in the area is exclusively dependent on the nest-boxes.

\section{Epirrita autumnata dynamics}

The presentation of the results of the insect census work is here restricted to the caterpillars of the geometrid moth Epirrita. The reason is that this is the only insect organism that was considered in relation to the fluctuations of the bird numbers. Its dramatic dynamics are illustrated in Figure 6. The period investigated covers three complete cycles with about ten years between the outbreak peaks. The duration of the outbreaks, counted as the number of years with ten or more caterpillars per 1000 short shoots, is five, four, and four years, respectively. The frequency of the caterpillars drops to almost zero between the outbreaks and is therefore not visible in the diagram. The bird census work started in 1963 apparently during an Epirrita outbreak, a remnant of which was registered when the insect census began in 1967 (only about one caterpillar per 1000 short shoots, therefore not visible in Figure 6).

Table 5. The mean temperature $\left({ }^{\circ} \mathrm{C}\right)$ of each of the three months during the investigation from 1963-1999. Medeltemperaturen för var och en av tre månader under fältarbetsåren 1963-1999.

\begin{tabular}{lllll}
\hline Month & Mean & SD & CV & Range \\
Månad & Medelvärde & Spridning & Spridning \% & Extremvärden \\
\hline May & 4.41 & 1.58 & 36 & $0.8-8.3$ \\
June & 10.22 & 1.65 & 16 & $7.4-13.6$ \\
July & 12.38 & 1.22 & 10 & $10.4-15.5$ \\
\hline
\end{tabular}




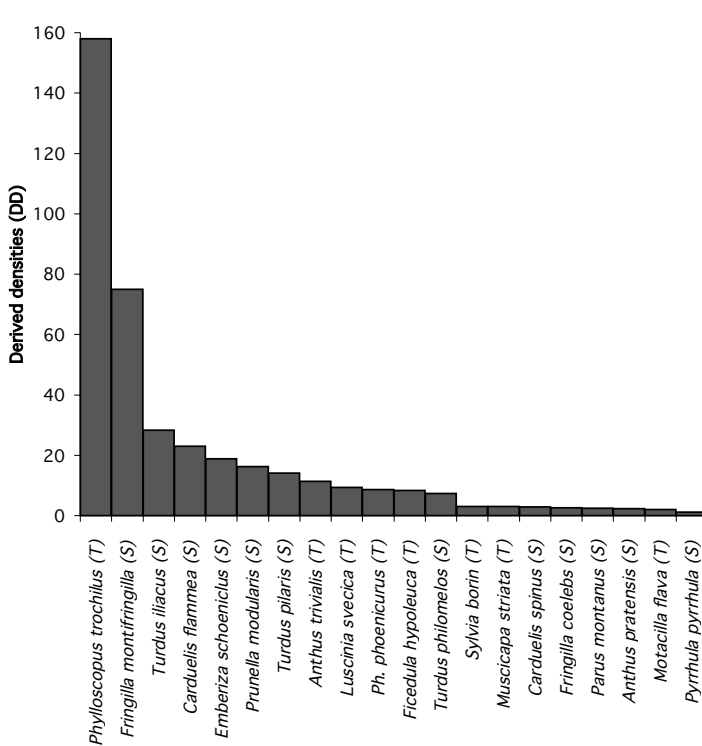

Figure 7. Frequency diagram showing the mean values of the derived density indices of the 20 regularly occurring species during the breeding season. $(S)=$ short-distance migrant, $(T)$ $=$ tropical, long-distance migrant.

Frekvensdiagram som visar medeltätheten (revir $\left./ \mathrm{km}^{2}\right)$ för de 20 småfågelarter som regelbundet förekommer $i$ studieområdet under häckningstiden. $(S)=$ kortdistansflyttare, $(T)=$ långdistans/tropikflyttare.

\section{Environmental temperature}

The calculated monthly mean temperatures $\left({ }^{\circ} \mathrm{C}\right)$ of all 37 years are listed in Appendix 4. A summary of characteristics is given in Table 5 and in the section dealing with the possible influences of temperature on the bird numbers.

\section{Analyses and discussion}

The composition of the passerine bird community

The mean densities of the 20 regularly occurring species are shown in the frequency diagram of Figure 7. Compared to the corresponding diagram for the 1965-1982 seasons (Enemar et al. 1984), four more species have been included, namely $A$. pratensis, M. flava, C. spinus, and P. pyrrhula. The reason is that they have appeared annually during the last 17 seasons. The density-based ranking of the species does not show any remarkable deviations from that of Enemar et al. (1984). The same species occupy the first seven positions in an unchanged order. Ph. trochilus and F. montifringilla are still and
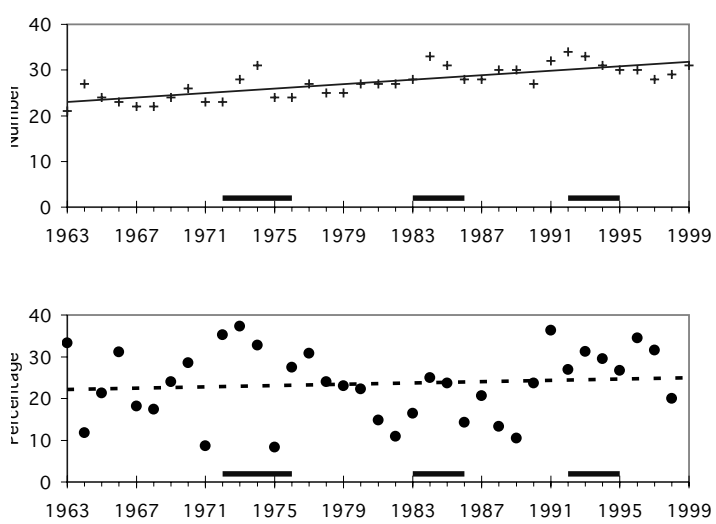

Figure 8. Year-to-year variation in the number of species breeding in the study area (plus signs, top panel) and the species turnover rate (black dots, bottom panel). The regression equations are $y=22.7+0.24 x, r=0.77, p<<0.001$ for the species numbers, and $\mathrm{y}=21.2+0.11 \mathrm{x}, \mathrm{r}=0.14$, n.s. for the turnover rates. The broad horizontal lines indicate the periods of mass occurrences of Epirrita caterpillars (see legend for Figure 5).

Variationen mellan åren i antalet närvarande arter i studieområdet, visad av serien med plus-tecken (övre diagrammet). Den heldragna linjen visar hur artantalet genomsnittligt ändrats under 37-årsperioden. Den antydda ökningen är statistiskt säkerställd. Serien med fyllda cirklar visar variationen $i$ omsättningen av arter mellan åren (undre diagrammet). Den streckade linjen representerar medelomsättningens ändring under åren. Den svaga lutningen är inte statistiskt säkerställd, vilket betyder att artomsättningen varit genomsnittligt oförändrad under de 37 åren. De tre grova linjerna nederst markerar åren med massförekomst av björkmätarlarver.

by far the dominant ones. They make up about $60 \%$ of the community. Among the new species only $C$. spinus has managed to find its way into the previous published sequence of species by occupying position no. 15, thus leaving the sparse species Parus montanus and $F$. coelebs behind.

Previous bird censuses in the Scandinavian subalpine birch forests have been listed by Ytreberg (1972), supplemented by Enemar et al. (1984). The 8-year study by Järvinen \& Rajasärkkä (1992) with references can now be added to the list. Hogstad (1975) reviewed the results and characterised the species composition of the habitat. He found that the density and composition of the bird content of the different plots were very similar and that $P h$. trochilus and $F$. montifringilla were the dominant species overall. The field data from the last three decades do not provide any reason to surmise that any radical changes in species composition have occurred in our study area. 


\section{Number of species}

The number of actual and potential breeding passerine species (excl. Corvidae) has fluctuated between 21 and 34 (Figure 8), with an annual mean of $26.7 \pm 5.33$ (SD) and a CV of $20 \%$. The curve shows three peaks with 31,33 , and 34 species occurring during the three periods of the Epirrita outbreak (see below). The linear regression of the number of species over time suggests an increase of between eight and nine seasonally documented species over the 37 years (b $=0.24, r=0.77, p<0.001)$, i.e. on average one new species every four years. Most of this increase occurred during the first half of the period (Figure 8 ). The main reason is that the irregularly occurring species have started to appear more often rather than that new species have shown up.

Most species that did not appear until the second half of the study period are truly accidental ones. Others, such as $P$. cinctus and $C$. chloris, tend to occur regularly. However, $P$. cinctus has disappeared over the last few years including the 2000 and 2001 seasons whereas $C$. chloris has continued to appear. Only three sparse species, C. familiaris, L. excubitor, and $E$. hortulana, observed during the first half of the study period, have been absent over the last two decades.

It should be pointed out that the moderate yet highly significant increase in the number of species over the investigated years is not associated with a corresponding increase in the community density (see below).

\section{Species turnover}

Calculations are restricted to those passerines that are confirmed or potential breeders in the habitat, totalling 46 species of which only 16 have appeared in all 37 seasons. These 16 species make up about $60 \%$ of the yearly average of the total number of species. This means that there has been considerable scope for species turnover between seasons. The turnover $(\mathrm{T})$ has been calculated, as a percentage, according to the generally used formula $\mathrm{T}=100(\mathrm{I}+\mathrm{E}) /$ $[0.5(\mathrm{~S} 1+\mathrm{S} 2) \mathrm{t}]$, where $\mathrm{I}$ and $\mathrm{E}$ are the number of immigrating and emigrating species, $\mathrm{S} 1$ and $\mathrm{S} 2$ the number of species present in the first and second season, respectively, and $t$ is the number of years between the compared seasons.

The species turnover between successive seasons $(\mathrm{t}=1)$ varied between $8 \%$ and $37 \%$ with a mean value of $30 \pm 8.7 \%$ (S.D.) and showed no significant trend over the 37-year period (Figure 8).

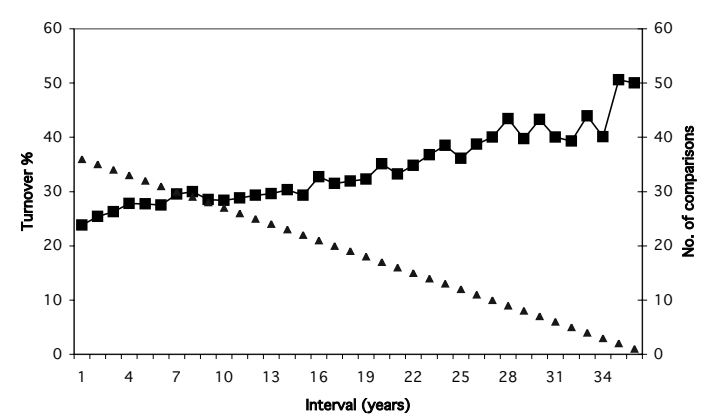

Figure 9. The relation between the mean species turnover rate (squares) and the number of years between the compared seasons $(\mathrm{y}=0.61 \mathrm{x}+23.05, \mathrm{r}=0.94, \mathrm{p}<0.001)$. Triangles show the numbers of comparisons the turnover rate is based on, ranging from one 36-year period to 36 one-year periods.

Diagram som visar hur artomsättningen stiger när intervallet mellan de jämförda åren ökar (kurvan med kvadraterna). Trianglarna anger hur många intervall som ligger till grund för de medelvärden som kurvan bygger på. För de 37 åren finns bara ett intervall på 36 år, men de blir fler ju kortare intervallen är, med 36 analyser av ettårsintervall.

The species turnover rate increased in line with the number of years between the compared seasons, from $20-25 \%$ to around $45 \%$ (Figure 9). This increase is partly a consequence of the upward trend in the annual number of species (Figure 8). It particularly affects the turnover rates over the longest time intervals because they are mainly based on the figures from the first (species-poor) and last (species-rich) parts of the investigated period.

Thirty species have been absent one season or more. The mean number of these irregularly occurring species per season is slightly more than eleven. Given that two compared seasons shared no such species, the calculated species turnover would be about $80 \%$. The latter figure may indicate an order of magnitude of "maximum average turnover rate". The calculated values of even the longest intervals are far from approaching this level (Figure 9). It is noteworthy that there is no indication of a downward trend towards the end of the diagram as observed in long-term investigations elsewhere (Svensson et al. 1984, Enemar et al. 1994).

Increasing turnover rates following longer intervals between compared seasons were found by Jones \& Diamond (1976), Diamond \& May (1977) and Abbott (1978). Their findings are similar to those of Bengtsson et al. (1997) who also showed that the community variability increases over time. Thus the time scale must thus be taken into account when comparing the variability of different communities. 


\section{The density fluctuations of the total community}

It is well known that the densities of the separate species may fluctuate more in the northern areas than in the southern ones (e.g. Järvinen 1979), which is true also for Ammarnäs (Figure 5). As expected, the mean annual density change of the total community is less pronounced with a CV of $21 \%$, which is much less than the mean $\mathrm{CV}, 65 \%$, of the 20 most frequently occurring passerine species. Nevertheless, according to a heterogeneity test, the density of the community varies highly significantly $\left(\chi^{2}=632, p<0.001\right)$. The lowest densities amount to less than $50 \%$ of the maximum levels (density indices 236 and 564, respectively, Figure 4). The community fluctuation can be compared with that of the deciduous woods of the BNP in Poland, i.e. 13 degrees of latitude further south. Wesolowski \& Tomialojc (1997) report that the highest density recorded exceeds the minimum density by about $44 \%$, and that the maximum increase between two successive seasons amounts to $13 \%$. The corresponding figures in our study area are $139 \%$ and $60 \%$. Clearly the fluctuation amplitude is higher further north.

There was no significant consistent trend in overall

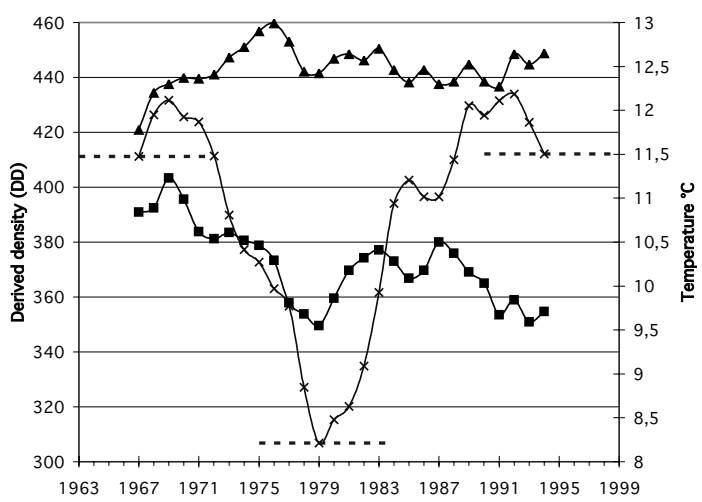

Figure 10. Moving 10-year means of the density of the total passerine bird community (crosses) together with the moving 10-year means of the environmental temperature of June (squares) and July (triangles). The stippled line shows the extension of three of the 10 year periods.

Variationen $i$ fågelsamhällets täthet presenterad $i$ form av medelvärden för alla de 28 10-årsperioder som ryms inom 37 årsperioden (s.k. glidande medelvärden, kurvan med kryss). De horisontella streckade linjerna visar utsträckningen av 10årsperioden för tre medelvärden. På samma sätt visas kurvorna för juni- och julitemperaturerna (kurvorna med kvadrater resp. trianglar). bird numbers over the years. The regression of the density over time shows only a slight increase $(b=$ $1.2, r=0.15$, n.s.). However, this does not exclude dramatic short-term density fluctuations. The most remarkable one is the reduction in bird numbers around the second decade of the 37-year period, as demonstrated by the moving density means of the available 28 successive 10 -year periods (Figure 10). These mean values show a low for the period 19751984, being significantly lower than the maximum densities that occurred during the beginning and the end of the investigated period (t-test, $\mathrm{p}<0.001$ for both comparisons). The continuous decline begins with the fourth 10-year period (1966-1975) and is followed by a nearly continuous increase that peaks during the third last period (1987-1996).

\section{The influence of environmental temperature on the total community}

Wiens (1989b) investigated the specific problems arising when analysing the response of bird populations to changing environmental factors. One of them is the occurrence of time lags in the response that makes it more difficult to distinguish possible relations between different parameters, especially in short-term investigations. We were able to test relationships between bird numbers and temperature, including time lags. The relation between the longterm trends of the bird density and temperature as demonstrated by their moving mean values was also investigated.

The environmental temperature may affect the bird density in various ways. At least three causal relationships are conceivable. (1) Spells of high temperature during the spring migration period, May and early June, apart from reducing the snow-covered area, are known to stimulate a prolongation of the migration routes with more birds arriving, especially in the actual northern border-line habitats. (2) The weather in June, including the temperature, may affect the breeding productivity in various ways, possibly influencing the bird numbers over the next few seasons. (3) The weather conditions in July are of importance for the final growth and maturation of the fledglings. Moreover, weather may affect the progress of the post-breeding recovery of the adult birds, with consequences for the prospects of surviving and returning to breed again next year. Therefore, the relationships between bird densities and mean temperature of each of three months have been investigated. The calendar periods of May, June, and July have been chosen as roughly 
Table 6. The correlation between the bird density of year $\mathrm{x}$ and the mean temperature of year $\mathrm{x}$, year $\mathrm{x}-1$ and year $\mathrm{x}-2$ for the months of May, June and July, and also between the density of year $\mathrm{x}$ with the combined temperatures of June year $\mathrm{x}-2$ and July $\mathrm{x}-1$. The correlations have been calculated for different durations, counted from the start of the 37-year period. $r=$ coefficient of correlation, $p=$ probability level, designated as n.s. (not significant) when $\mathrm{p}>0.05$.

Sambandet mellan fågeltätheten ett bestämt år $(x)$ och medeltemperaturen samma år $(x)$ eller medeltemperaturen föregående år ( $x$-1) eller förföregående år ( $x$-2), allt för de tre månaderna maj, juni och juli var för sig. Sambandet är prövat för perioder om 10, 20, 30 till alla 37 åren (All), räknat från projektets start 1963. r anger styrkan och riktningen av sambandet. Siffran föregås av minustecken om sambandet är omvänt (högre temperatur följs av lägre fägeltäthet). Saknas minustecken är sambandet direkt (högre temperatur följs av högre fägeltäthet). Om siffran följs avn.s. betyder detatt inget säkert samband finns, medan en siffra (0.05 osv) betyder att ett statistiskt säkert samband tycks finnas, ju lägre värde desto säkrare samband.

\begin{tabular}{|c|c|c|c|c|c|c|c|c|c|}
\hline \multirow{3}{*}{$\begin{array}{l}\text { Month } \\
\text { Månad }\end{array}$} & \multirow{3}{*}{$\begin{array}{l}\text { Temperature } \\
\text { year } \\
\text { Temperatur-år }\end{array}$} & \multicolumn{8}{|c|}{ Duration, years Period, antal år } \\
\hline & & \multicolumn{2}{|c|}{10} & \multicolumn{2}{|c|}{20} & \multicolumn{2}{|c|}{30} & \multicolumn{2}{|c|}{ All } \\
\hline & & $\mathrm{r}$ & $\mathrm{p}<$ & $\mathrm{r}$ & $\mathrm{p}<$ & $\mathrm{r}$ & $\mathrm{p}<$ & $\mathrm{r}$ & $\mathrm{p}<$ \\
\hline \multirow[t]{3}{*}{ May } & $\mathrm{x}$ & -0.32 & n.s. & -0.03 & n.s. & 0.19 & n.s. & -0.13 & n.s. \\
\hline & $x-1$ & -0.41 & n.s. & -0.07 & n.s. & -0.08 & n.s. & -0.09 & n.s. \\
\hline & $x-2$ & 0.00 & n.s. & -0.13 & n.s. & 0.00 & n.s. & -0.09 & n.s. \\
\hline \multirow[t]{3}{*}{ June } & $\mathrm{x}$ & -0.69 & 0.05 & -0.14 & n.s. & -0.05 & n.s. & -0.05 & n.s. \\
\hline & $x-1$ & 0.55 & n.s. & 0.34 & n.s. & 0.35 & n.s. & 0.22 & n.s. \\
\hline & $x-2$ & 0.48 & n.s. & 0.56 & 0.02 & 0.45 & 0.02 & 0.36 & 0.05 \\
\hline \multirow[t]{3}{*}{ July } & $\mathrm{x}$ & -0.42 & n.s. & -0.12 & n.s. & -0.03 & n.s. & 0.00 & n.s. \\
\hline & $x-1$ & 0.63 & 0.05 & 0.47 & 0.05 & 0.30 & 0.02 & 0.21 & n.s. \\
\hline & $x-2$ & 0.47 & n.s. & 0.03 & n.s. & 0.08 & n.s. & 0.05 & n.s. \\
\hline June+July & $(x-2)+(x-1)$ & 0.70 & 0.05 & 0.57 & 0.01 & 0.47 & 0.01 & 0.42 & 0.02 \\
\hline
\end{tabular}

representing the migration/arrival, breeding, and post-breeding periods, respectively.

In Table 5, the mean temperature for the whole 37year period is presented for each of the three months, which differ significantly (t-tests, $\mathrm{p}<0.001)$. The difference between the coldest and warmest years amounts to about seven (May), six (June), and five (July) degrees. The temperature ranges of the adjacent months are only moderately overlapping (Table 5). The monthly temperature means of May and June and of June and July are not significantly correlated ( $\mathrm{r}=0.00$ and 0.31 , n.s., respectively). The monthly means did not change significantly over the 37 year study period (May: $r=-0.19$, June: $r=-0.15$, July: $r=0.25$, all n.s.), i.e. there was no trend towards a warmer climate.

The inter-seasonal relationship between the temperature and bird density was investigated by calculating correlation coefficients (Table 6). There was no general relation between the temperature means of the three months and the bird density of the same season. The indicated negative correlation between the May temperature and bird density will be discussed later.

The correlations between the May temperature and the bird densities of the ensuing two seasons were insignificant. The June temperatures showed positive r-values when related to the bird density of the following two seasons, but there was a significant correlation only for the second one (Table 6). A reasonable interpretation may be that more offspring are raised in a warmer June and that most of the surviving young birds do not establish permanent territories and breed until two years later. As pointed out above, only territorial birds are included in the density reference used to derive the density indices. Many passerines of the actual species reach sexual maturity towards the end of their first year, although generally a varying fraction of these one-year old birds do not breed until a year later (see Glutz von Blotzheim \& Bauer (1985-1997)). The frequency of postponed breeding may show regional differences. It is possibly more common in the harsh environments in the far north as established for F. hypoleuca in the 
study area (Nyholm 1986) and L. svecica in northernmost Finland (Järvinen \& Pietiäinen 1983). Our results indicate that this may also be true for other passerine species in the region.

The bird density was generally correlated with the July temperature with a delay of one year, with no demonstrable effect after two years (Table 6). High July temperatures may imply an improved nutritional situation for the fledglings and the adult birds. The young of many passerines are fed by their parents for twice as long outside the nest as in it (Martin 1987 with references). It follows that feeding may continue into July for many passerines in our study area, e.g. in F. montifringilla (Lindström et al. MS). Moreover, the yearlings as well as the adult birds will be better prepared to endure the strains of the migration and wintering periods, which means that more birds will survive and return the following year. A fraction of the returning one-year old birds may refrain from breeding, the two-year old and older birds probably account for the main bulk of the correlation between the community density and the July temperature of the previous season.

As a consequence of the interpretations above, we would expect the combination of the mean temperatures of June the first year and July the second year to show a closer correlation to the bird density of the third year than the temperatures of the individual months. This was confirmed by the test presented in Table 6 . The correlation was significant for all investigated period lengths. This combination of the mean temperatures of the two months will be referred to below as the combined June and July temperatures.

The residual density variation not explained by the combined June and July temperatures was calculated and correlated with the May temperatures. The correlation coefficients were all negative and of higher numerical values than those for May in Table 6 . That of the whole 37 -year period was statistically significant $(r=-0.37, n=35, p<0.05)$. This relation can be explained by the fact that the whole study area is located on south-facing mountain slopes, thus well exposed to and warmed by solar radiation, which is important, especially in springtime. Our study area therefore loses its snow cover earlier than the surrounding areas that are located in less exposed positions or at higher levels. In cold springs, the arriving birds may find only limited parts of the area sufficiently snow-free to occupy. This most likely means a certain concentration of established territories in the study area.

The long-term bird density trend, as demonstrated by the moving means of the 10 -year periods, was compared with the corresponding moving means of the June and July temperatures (Figure 10). Three things are immediately apparent.

(1) The main course of the June temperature curve strongly resembles that of the bird density during the first 17 of the 28 periods $(\mathrm{r}=0.81, \mathrm{n}=17$, $\mathrm{p}<0.001)$. This indicates that factors related to the environmental June temperature have caused the marked bird density dip around 1980 .

(2) The two curves tended to diverge from the $18^{\text {th }} 10$-year period and onwards, resulting in a negative correlation $(\mathrm{r}=-0.68, \mathrm{n}=11, \mathrm{p}<0.02)$. This is in accordance with the information given in Table 6 , where the r-values of the correlation between the mean monthly temperatures and the bird densities declined when the last period of the 37 years was included in the test. Obviously, factors other than those positively correlated with the environmental temperature could maintain or raise the bird numbers, even when the temperature trend decreases significantly.

(3) The July temperature was negatively correlated with the density trend of the bird community $(\mathrm{r}=-0.43, \mathrm{n}=28, \mathrm{p}<0.05)$. The explanation could be the fact that practically all fledglings are produced in June. Therefore, a warmer July in the same season cannot do more than augment the quality and the survival rate of the fledglings already produced. This means that the correlation runs the risk of becoming negative when the reproductive rate during cold June months decreases, all the more as the moving temperature trends of June and July tend to be negatively correlated.

No significant relation could be established between the long-term trend of the temperature in May and the density of the bird community, with the exception of the first ten periods. The latter show a negative correlation $(\mathrm{r}=-0.70, \mathrm{p}<0.05)$.

In summary, temperature-related environmental factors seem to affect the fluctuations of the total bird community among the breeding seasons. An increased bird density in the study area follows a chillier May, presumably due to a delayed thaw that forces the arriving birds to gather in the limited snow-free areas. The monthly temperature means of June and July are positively correlated to the bird densities with a time lag of two and one year, respectively. The mean temperature in June, when most fledglings are produced, seems to be the most important one. There are periods when factors other than the positively temperature-related ones may decide the direction of the population development. 
Golovatin (2002) found that the density of passerine birds were positively correlated to the spring and summer temperature of the preceding breeding season in a $9.3 \mathrm{~km}^{2}$ study area in the lower $\mathrm{Ob}$ region of Russia. The 11-year investigation was carried out in a subarctic habitat comprising moss bogs and "afforested moss bogs". He assumed that the correlation was mainly due to increased survival rate of the fledged young in warmer seasons, i.e. a similar effect to that following the increased July temperature in our study. Golovatin also found that the spring temperature did not significantly influence the bird density the same year but instead affected the distribution of birds within larger areas, which is similar to our interpretation of the effect of the May temperature variation.

There are some studies at the species level demonstrating how a temperature-related change in the reproductive rate is followed by a density alteration in the ensuing season, as in F. hypoleuca (Virolainen 1984). Järvinen (1989) showed that the betweenyear variability in temperature is greater in northern than in southern Finland and that the within-season predictability is far higher in the north. This should select for adjusting the breeding performance to the environmental conditions (contrary to the situation in the south). In fact, in his 22-year study A. Järvinen found significant positive correlation between the temperature in the latter half of June and the female weight, egg volume, hatching and nesting success in the subalpine birch zone at Kilpisjärvi $\left(65^{\circ} \mathrm{N}\right)$. The investigated species was $F$. hypoleuca but the results are probably valid for the small passerine species in general (Järvinen \& Väisänen 1984). It can therefore be expected that the breeding outcome will correlate with the environmental temperature in June, even to the extent that it is reflected in the density dynamics of the bird community. This assumption is strongly supported by the bird density fluctuations related to the June temperature in our study area.

\section{Fluctuations in the species populations}

Twenty of the most common species are presented in Table 7 along with selected statistical population parameters. These species make up $98.4 \%$ of the average density of the total passerine community. The fluctuations between years are often considerable (Figure 5).

According to the heterogeneity tests no less than 15 species vary significantly between seasons. Those species that remain constant are all represented by low-density figures. Nine species show significant trends in their population development, five of them increasing and four declining. These species all belong to the less abundant ones.

It is evident that a comprehensive comparison with the fluctuation patterns of the Swedish bird populations is futile at present. A nation-wide birdmonitoring programme was started in Sweden in 1975 and a summary of the results has recently been published (Svensson \& Lindström 2002). The fluctuations in the species populations have been followed with the aid of point counts. So far, only a minor part of the fieldwork has been carried out in northern Sweden and some northern species are therefore not recorded in large enough numbers, such as F.montifringilla and L. svecica. Consequently, comparisons cannot answer the question as to whether the population changes in the study area reflect more wide-ranging fluctuations. However, there are a few short-term concordant changes, such as the approximately $50 \%$ reduction of $A$. trivialis in Sweden between 1987 and 1993 and the 80\% drop in our study area between 1988 and 1993. The abundant Ph. trochilus shows no long-term trend whereas this species has increased significantly in our study area between 1975 and 1999 (linear regression upon time, $\mathrm{r}=0.45, \mathrm{n}=25, \mathrm{p}<0.001)$. This may partly reflect the fact that the two compared populations belong to different subspecies, $P h$. t. acredula in the north and mainly $P$ h. t. trochilus in the south, probably with different migration strategies. The rising numbers at Ammarnäs could partly have been a consequence of the significant population reduction that occurred there in the late 1970s. This population decline may not have involved the southern parts of the country.

The moving 10-year means of the majority of the species show a similar density trend to that of the total community, i.e. a steady decline over many years preceding the minimum value of the 19751984 period, followed by an increase during a varying number of years. Ph. trochilus, F. montifringilla and T. iliacus, which make up $65 \%$ of the total assembly, follow the curve of the total assembly very closely. $A$. trivialis, Ph. phoenicurus, T. pilaris, M. striata, F. hypoleuca, Parus montanus, F. coelebs, and C. spinus also show the same trend with the minimum period between 1975 and 1984, whereas the minimum periods of $P$. modularis, L. svecica, T. philomelos, $S$. borin, and E. schoeniclus are delayed between one and three years. The moving means of $C$. flammea and of the sparse A. pratensis, M. flava and $P$. pyrrhula show quite different fluctuation patterns. 


\section{Environmental temperature and species density fluctuations}

Even if the environmental temperature shows interesting and partly clarifying relations to the density fluctuations in the total bird assembly, it does not follow that this applies to all of the species. A drawback is, however, that many species are too scarce to provide reliable information. The following calculations were therefore restricted to the 14 species with a mean density index of three or more per $\mathrm{km}^{2}$ (Table 8). There are few statistically significant correlations between the densities of these species and the combined temperatures of June and July (Table 8). However, the positive correlation coefficients are dominant (47 out of the $56 \mathrm{r}$-values), which was to be expected, since the correlations for the total community are significant throughout (Table 7). The main observations are given under the following six points.

1. It is surprising that the most abundant of all species, Ph. trochilus, totally lacks significant correlations with the environmental temperature. The reason could be that the derived density indices deviate greatly from the territorial densities as established in the study plots. However, correlation tests using the study plot densities generally provide results that do not differ significantly from those shown in Table 8. This indicates that the species is relatively insensitive to temperature fluctuations. Other regulating factors not related to the temperature may be dominant. However, there was a positive correlation between the moving means of the population density and the June temperature (the temperature curve, see Figure 10). The correlation was significant during the first 20 of the 28 periods ( $\mathrm{r}=0.84, \mathrm{p}<0.001)$. Obviously Ph. trochilus shares a "long-term" dependence on certain temperatureassociated factors with the majority of the passerine species in the investigated area. The moving 10 -year means of the July temperature was negatively and significantly correlated with the population density trend $(\mathrm{r}=-0.51, \mathrm{n}=28, \mathrm{p}<0.01)$, a similar though more pronounced relation than that of the total bird

Table 7. Mean derived densities (DD, number of territories $/ \mathrm{km}^{2}$ ) and standard deviations (SD) of the 20 commonest smaller passerines (species observed in the study area in at least 32 seasons). $\mathrm{CV}=$ coefficient of variation as a percentage of the mean, $\chi^{2}=$ heterogeneity value, $b=$ slope of the linear regression of the DD upon time (cf. Fig. $5), \mathrm{p}=$ level of significance for $\chi^{2}$ and $\mathrm{b}$, respectively.

Medelantalet revir $/ \mathrm{km}^{2}(D D)$ för de smärre tättingar som observerats i studieområdet under minst 32 av de 37 säsongerna. $S D=$ spridningsvärdet, $C V=$ spridningsvärdet i procent, $\chi^{2}=$ heterogenitetsvärde som anger graden av olikhet $i$ antal mellan säsongerna, $b=$ lutningsvärdet för regressionslinjen för artens täthetsvariation (jfr. Fig. 5), $p=$ sannolikhetsvärdet för $\chi^{2}$ respektive $b$.

\begin{tabular}{lrrrrrrr}
\hline Species/Art & $\mathrm{DD}$ & $\mathrm{SD}$ & $\mathrm{CV}$ & $\chi^{2}$ & $\mathrm{p}<$ & $\mathrm{b}$ & $\mathrm{p}<$ \\
\hline Anthus trivialis & 11.3 & 5.18 & 46 & 84.8 & 0.001 & -0.07 & $\mathrm{n} . \mathrm{s}$. \\
Anthus pratensis & 2.0 & 2.40 & 120 & 103.5 & 0.001 & 0.12 & 0.001 \\
Motacilla flava & 1.7 & 1.58 & 93 & 52.3 & $\mathrm{n} . \mathrm{s}$. & 0.11 & 0.001 \\
Prunella modularis & 16.1 & 5.60 & 35 & 70.4 & 0.001 & -0.13 & n.s. \\
Luscinia svecica & 9.2 & 5.45 & 59 & 116.2 & 0.001 & 0.00 & n.s. \\
Phoenicurus phoenicurus & 8.6 & 4.79 & 56 & 96.1 & 0.001 & -0.06 & n.s. \\
Turdus pilaris & 14.0 & 7.75 & 55 & 154.3 & 0.001 & 0.18 & n.s. \\
Turdus philomelos & 7.3 & 3.30 & 45 & 53.3 & $\mathrm{n} . \mathrm{s}$. & -0.20 & 0.001 \\
Turdus iliacus & 28.2 & 8.93 & 32 & 101.7 & 0.001 & -0.02 & n.s. \\
Sylvia borin & 3.1 & 2.92 & 95 & 98.2 & 0.001 & -0.19 & 0.001 \\
Phylloscopus trochilus & 156.5 & 33.93 & 22 & 263.4 & 0.001 & 0.34 & n.s. \\
Muscicapa striata & 3.0 & 2.07 & 69 & 49.1 & $\mathrm{n} . \mathrm{s}$. & 0.13 & 0.001 \\
Ficedula hypoleuca & 8.3 & 5.06 & 61 & 118.0 & 0.001 & -0.25 & 0.001 \\
Parus montanus & 2.5 & 1.64 & 67 & 38.2 & $\mathrm{n} . \mathrm{s}$. & -0.04 & 0.02 \\
Fringilla coelebs & 2.5 & 1.86 & 74 & 50.0 & $\mathrm{n} . \mathrm{s}$. & -0.01 & n.s. \\
Fringilla montifringilla & 74.1 & 27.42 & 37 & 364.6 & 0.001 & 0.60 & n.s. \\
Carduelis spinus & 2.6 & 3.18 & 121 & 146.7 & 0.001 & 0.16 & 0.001 \\
Carduelis flammea & 22.7 & 17.98 & 79 & 516.1 & 0.001 & 0.02 & n.s. \\
Pyrrhula pyrrhula & 1.0 & 1.12 & 108 & 67.2 & 0.03 & 0.05 & 0.01 \\
Emberiza schoeniclus & 18.8 & 6.54 & 35 & 82.1 & 0.001 & -0.07 & n.s. \\
\hline
\end{tabular}


Table 8 . The correlation between the density of 14 species populations of year $\mathrm{x}$ and the the mean of the sum of the June temperature of year $(\mathrm{x}-2)$ and the July temperature of year $(\mathrm{x}-1)$. The correlation coefficients have been calculated for different durations, counted from the start of the 37-year project. The species are listed after their mean population density (cf. Figure 7). Species with a mean derived density of less than three territories per $\mathrm{km}^{2}$ have been excluded. $\mathrm{r}=$ coefficient of correlation, $\mathrm{p}=$ probability level, designated as n.s. when $\mathrm{p}>0.05$.

Sambandet mellan populationstätheten för de 14 allmännaste arterna och den sammanlagda medeltemperaturen för juni två år och juli ett år tidigare. Informationen i tabellen tolkas på sätt som förklaras i Tabell 6. Enda skillnaden är att de positiva $r$-värdena här försetts med +-tecken för att tydligt visa att de flesta arterna, för de flesta testade periodlängderna, tenderar att variera i takt med temperaturvariationen.

\begin{tabular}{|c|c|c|c|c|c|c|c|c|}
\hline \multirow[b]{3}{*}{ Species Art } & \multicolumn{8}{|c|}{ Duration, years Period, antal år } \\
\hline & \multicolumn{2}{|c|}{10} & \multicolumn{2}{|c|}{20} & \multicolumn{2}{|c|}{30} & \multicolumn{2}{|c|}{35} \\
\hline & $\mathrm{r}$ & $\mathrm{p}<$ & $\mathrm{r}$ & $\mathrm{p}<$ & $\mathrm{r}$ & $\mathrm{p}<$ & $\mathrm{r}$ & $\mathrm{p}<$ \\
\hline Phylloscopus trochilus & -0.19 & n.s. & +0.19 & n.s. & +0.18 & n.s. & +0.11 & n.s. \\
\hline Fringilla montifringilla & +0.77 & 0.01 & +0.55 & 0.02 & +0.37 & 0.05 & +0.37 & 0.05 \\
\hline Turdus iliacus & +0.62 & n.s. & +0.37 & n.s. & +0.34 & n.s. & +0.34 & 0.05 \\
\hline Carduelis flammea & +0.46 & n.s. & +0.48 & 0.05 & +0.38 & 0.05 & +0.39 & 0.05 \\
\hline Emberiza schoeniclus & -0.05 & n.s. & +0.15 & n.s. & +0.19 & n.s. & +0.17 & n.s. \\
\hline Prunella modularis & +0.04 & n.s. & +0.29 & n.s. & +0.30 & n.s. & +0.24 & n.s. \\
\hline Turdus pilaris & +0.52 & n.s. & +0.39 & n.s. & +0.38 & 0.05 & +0.28 & n.s. \\
\hline Anthus trivialis & -0.31 & n.s. & -0.18 & n.s. & +0.06 & n.s. & +0.13 & n.s. \\
\hline Luscinia svecica & +0.18 & n.s. & +0.27 & n.s. & +0.27 & n.s. & +0.23 & n.s. \\
\hline Ph. phoenicurus & +0.11 & n.s. & +0.32 & n.s. & +0.39 & 0.05 & +0.33 & 0.05 \\
\hline Ficedula hypoleuca & +0.13 & n.s. & +0.09 & n.s. & +0.10 & n.s. & +0.13 & n.s. \\
\hline Turdus philomelos & -0.45 & n.s. & +0.02 & n.s. & +0.07 & n.s. & +0.09 & n.s. \\
\hline Sylvia borin & -0.82 & 0.01 & -0.34 & n.s. & -0.25 & n.s. & -0.20 & n.s. \\
\hline Muscicapa striata & +0.32 & n.s. & +0.28 & n.s. & +0.23 & n.s. & +0.20 & n.s. \\
\hline
\end{tabular}

community. The same interpretation as for the total community might be valid in this case.

2. The fluctuations of $F$. montifringilla show the strongest positive correlation with the combined June and July temperatures (Table 8). This was hardly expected, due to the fact that this species, as documented below, is significantly affected by the Epirrita cycles, which could at least partly obscure the response to the temperature fluctuations. When each of the two months were investigated separately with the same time lags taken into account, it is clear that the July temperature was the most important with highly significant $r$-values throughout the 37year period $(p<0.01$ to $<0.001)$, whereas the $r$-values of the June temperature were far from being statistically significant. This indicates that bad environmental conditions in July can severely reduce the increased reproductive output resulting from the rich supply of Epirrita larvae in June (but see Lindström et al. MS).

3. The density of $C$. flammea shows the second strongest correlation with the temperature fluctuations (Table 8). In contrast to F. montifringilla, the June temperature of two years previously is most important, manifested by significant correlations for the three longest year periods ( $p<0.05$ to $p<$ 0.01 ), whereas the bird density correlates insignificantly with the July temperature.

4. The density fluctuations of the thrushes $T$. iliacus and T. pilaris show a rather weak correlation with the combined June and July temperatures (Table 8). However, they resemble $C$. flammea in that the temperature in June is apparently of the utmost importance for their reproductive output, which is indicated by the fact that it correlates positively and significantly with the bird density figures two years later $(\mathrm{p}<0.01$ for three of the four tested period lengths, both species).

5. As described above, the 10 -year moving density means of 11 species closely followed that of the total community and they were significantly correlated at varying probability levels with the 10 -year moving means of the June temperature during the first three quarters of the 37-year period.

6. The May mean temperatures generally showed an insignificant negative correlation to the density of the total bird community in that season (Table 6). No less than ten of the 14 species in Table 8 show 
population fluctuation patterns that are contrary to the May temperature variation, some of them significantly. This applies to $P$ h. trochilus $(\mathrm{r}=-0.34$, $\mathrm{p}<0.05)$, T. iliacus $(\mathrm{r}=-0.41, \mathrm{p}<0.02)$, and T. pilaris $(\mathrm{r}=-0.54, \mathrm{p}<0.001)$. The remaining seven species, C. flammea, E. schoeniclus, P. modularis, L. svecica, T. philomelos, S. borin, and M. striata, all show insignificant $r$-values varying from -0.13 to -0.27 . Four species tend to be positively correlated with the May temperature, F. montifringilla, A. trivialis, $P h$. phoenicurus, and $F$. hypoleuca. The latter two show significant r-values for the first half of the 37-year period.

In summary, the density fluctuations of most species tend to be positively correlated with the combined June and July temperatures. However, only few correlations are statistically significant. Each of the separate months is responsible for a significant correlation with a time lag of one (July) or two (June) years for a few species. The moving 10year means of most species populations correlate positively and significantly with the moving means of the June temperatures during a greater part of the 37-year period.

\section{The influence of the Epirrita autumnata outbreaks}

The green Epirrita caterpillars unquestionably constitute part of the food with which the parent birds feed their young as demonstrated for T. iliacus (Arheimer 1978), C. flammea (Enemar \& Nyström 1981 ) and F. montifringilla (Hogstad 1988). Moreover, birds of various species have been observed carrying green-coloured food portions to their nests during the outbreak seasons. The marked appearance and disappearance of such a superabundant food source may affect the bird density fluctuations. The following two points should be borne in mind when interpreting the relations between the Epirrita cycles and the bird numbers.

1) The nutritional quality of the caterpillars as food for the birds may decline during the last outbreak years, for example as a side effect of the birches' chemical defence against the larval attacks. The interaction between the Epirrita caterpillars and the birches has been investigated (e.g. Haukioja 1980, Haukioja \& Hanhimäki 1985, Hanhimäki \& Senn 1992) and a number of significant chemical substances produced by the birches and their likely relation to the caterpillar growth are known (Suomela et al. 1995, Ossipov et al. 2001). The question is whether any of these substances affect the palatability of the grazing caterpillars from the birds' point of view. Anyhow, the size or mass of the caterpillars and pupae seems to decline during the final years of an outbreak (Hogstad 1996, Kaitaniemi et al. 1999).

2) The vegetation is affected by the grazing larvae to varying degrees, in the form of defoliation, reduced flowering and seed production of birches and various herbs, perhaps also in an impoverished insect fauna (cf. e.g. Selås et al. 2001). This might be a disadvantage for some bird species.

It is reasonable to assume that the superabundance of caterpillars during the Epirrita outbreaks would entice more bird species than usual to settle and breed in the study area. A moderate response is indicated by the curve showing the yearly number of species over the 37 seasons (Figure 8 ). The three peaks with 31,33 , and 34 species occur during the first, second and third Epirrita period, respectively. The species numbers are positively correlated with the caterpillar abundance over the first ten $(\mathrm{r}=0.82$, $\mathrm{p}<0.01)$ and twenty years $(\mathrm{r}=0.53, \mathrm{p}<0.02)$. The significant correlation disappears after 1984 .

The possible relation between the outbreaks of the moth caterpillars and bird densities has been investigated by calculating the correlation coefficients, thereby considering possible time lags and even anticipatory reactions. Three periods were investigated, starting at the beginning of the insect census work and extending over 10, 20 and 33 seasons. They include one, two, and three complete Epirrita outbreaks, respectively. The results of the calculations of the total passerine community (excl. Corvidae) and the 14 most abundant species have been studied. The results of the calculations regarding the community and five selected species can be found in Table 9. There are relatively few significant $r$-values, and the insignificant positive and negative coefficients are of about the same frequency. This is also true for the remaining nine species not included in the table.

The only species that shows a highly significant relation to the Epirrita cycles is F. montifringilla (Table 9), a fact that has been repeatedly established (Silvola 1967, Hogstad 1969, 2000, Ytreberg 1972, Enemar et al. 1984, Lindström 1987). Its density is high in years with a mass occurrence of caterpillars. The density also increases significantly one year earlier, leading to somewhat higher correlation coefficients. However, there is no significant correlation with two years earlier, which means that the species responds very quickly and strongly in seasons marking the start of a new mass outbreak, probably with less than ten larvae per 1000 short shoots. The habitat may be "saturated" with 
Table 9. The correlation between the bird density (total passerine community, selected species) of year $\mathrm{x}$ and the abundance of Epirrita larvae the same year (x), the following year $(\mathrm{x}+1)$, and the two preceding years $(\mathrm{x}-1)$ and (x-2). The correlations have been calculated for different durations counted from the start of the Epirrita investigations (1967). $\mathrm{r}=$ coefficient of correlation, $\mathrm{p}=$ probability level, designated as n.s. when $\mathrm{p}>0.05$.

Sambandet mellan tätheterna år x för dels hela fågelsamhället, dels valda arter, och förekomsten av fjällbjörkmätarlarver (Epirrita) samma år $(x)$, efterföljande år $(x+1)$ och de föregående båda åren $(x-1)$ och $(x-2)$. Tre perioder räknade från 1967 har testats. Tabellinformationen $i$ övrigt (r-värden, n.s., 0.05, osv.) skall tolkas enligt förklaringen i Tabell 6.

\begin{tabular}{|c|c|c|c|c|c|c|c|}
\hline & \multirow{3}{*}{$\begin{array}{c}\text { Epirrita year } \\
\text { Larv-år }\end{array}$} & \multicolumn{6}{|c|}{ Duration, years Period, antal år } \\
\hline & & \multicolumn{2}{|c|}{10} & \multicolumn{2}{|c|}{20} & \multicolumn{2}{|c|}{ All Alla } \\
\hline & & $\mathrm{r}$ & $\mathrm{p}<$ & $\mathrm{r}$ & $\mathrm{p}<$ & $\mathrm{r}$ & $\mathrm{p}<$ \\
\hline Total community & $\mathrm{x}$ & 0.37 & n.s. & 0.41 & n.s. & 0.18 & n.s. \\
\hline \multirow[t]{3}{*}{ Hela fågelsamhället } & $x+1$ & 0.63 & 0.05 & 0.47 & 0.05 & 0.24 & n.s. \\
\hline & $x-1$ & -0.20 & n.s. & 0.19 & n.s. & 0.04 & n.s. \\
\hline & $x-2$ & -0.49 & n.s. & 0.21 & n.s. & 0.22 & n.s. \\
\hline \multirow[t]{4}{*}{ Fringilla montifringilla } & $\mathrm{x}$ & 0.77 & 0.01 & 0.70 & 0.001 & 0.59 & 0.001 \\
\hline & $x+1$ & 0.87 & 0.01 & 0.83 & 0.001 & 0.66 & 0.001 \\
\hline & $x-1$ & 0.04 & n.s. & 0.16 & n.s. & 0.13 & n.s. \\
\hline & $x-2$ & -0.36 & n.s. & -0.14 & n.s. & -0.11 & n.s. \\
\hline \multirow[t]{4}{*}{ Emberiza schoeniclus } & $\mathrm{x}$ & 0.48 & n.s. & 0.29 & n.s. & 0.11 & n.s. \\
\hline & $x+1$ & 0.23 & n.s. & 0.06 & n.s. & -0.02 & n.s. \\
\hline & $x-1$ & 0.35 & n.s. & 0.23 & n.s. & 0.10 & n.s. \\
\hline & $x-2$ & -0.01 & n.s. & 0.51 & 0.05 & 0.51 & 0.01 \\
\hline \multirow[t]{4}{*}{ Anthus trivialis } & $\mathrm{x}$ & 0.34 & n.s. & 0.67 & 0.01 & 0.18 & n.s. \\
\hline & $x+1$ & 0.45 & n.s. & 0.43 & n.s. & 0.02 & n.s. \\
\hline & $x-1$ & 0.39 & n.s. & 0.71 & 0.001 & 0.41 & 0.02 \\
\hline & $x-2$ & 0.44 & n.s. & 0.70 & 0.001 & 0.60 & 0.001 \\
\hline \multirow[t]{4}{*}{ Luscinia svecica } & $\mathrm{x}$ & 0.00 & & -0.06 & n.s. & -0.05 & n.s. \\
\hline & $x+1$ & 0.45 & n.s. & 0.11 & n.s. & 0.08 & n.s. \\
\hline & $x-1$ & 0.40 & n.s. & 0.34 & n.s. & 0.28 & n.s. \\
\hline & $x-2$ & 0.36 & n.s. & 0.52 & 0.02 & 0.48 & 0.01 \\
\hline \multirow[t]{4}{*}{ Carduelis flammea } & $\mathrm{x}$ & -0.19 & n.s. & -0.24 & n.s. & -0.18 & n.s. \\
\hline & $x+1$ & -0.12 & n.s. & -0.19 & n.s. & -0.11 & n.s. \\
\hline & $x-1$ & -0.24 & n.s. & -0.30 & n.s. & -0.26 & n.s. \\
\hline & $x-2$ & -0.02 & n.s. & -0.02 & n.s. & -0.02 & n.s. \\
\hline
\end{tabular}

caterpillars from the bird's point of view very early in the cycle, i.e. years before the peaks of mass occurrence. Furthermore, the bird density tends to decline when the caterpillars are still abundant(Figure 6). This could be a reaction to a change in caterpillar quality brought about by the anti-predator reactions of the birches. Anyhow, the impression is that the increase and decrease of $F$. montifringilla precede that of the Epirrita caterepillars by about one season. The early density increase of finches is also indicated by the corresponding curves obtained in a Norwegian subalpine birch forest (Hogstad 2000).

The increased reproductive output during the outbreak years (Lindström 1987, Hogstad 2000, Lindström et al. MS) is not followed by a population increase in the subsequent two seasons. The birds apparently disappear, which is in accordance with the nomadic behaviour of the species (Mikkonen 1983, Hogstad 1985), which has little or no site tenacity (Lindström 1987). As demonstrated above, 
the F. montifringilla fluctuation is strongly correlated with the mean July temperature of the previous year. Therefore the tests have been repeated making allowance for the effect of the July temperature. The results showed that the correlation between the residual variation of $F$. montifringilla and the occurrence of caterpillars did not diverge significantly from those presented in Table $9(\mathrm{r}=$ $0.64,0.62$ and 0.51 for Epirrita year x, and $0.84,0.82$ and 0.63 for year $(x+1)$, all with $p$-values of 0.01 or 0.001 , whereas the $\mathrm{r}$-values of the years $(\mathrm{x}-1)$ and $(\mathrm{x}-2)$ remained far from significant).

The densities of $F$. montifringilla can also rise to high or moderate peaks between the Epirrita outbreaks as was the case in 1968, 1980 and 1989 (Figure 6). This indicates that F. montifringilla is not entirely dependent on the Epirrita caterpillars for its accumulation and breeding start. An unknown food source may be of importance, perhaps favoured by a habitat not heavily grazed by caterpillars. The significance of the breeding during these seasons cannot be evaluated at present. The birds sometimes abandon their nests during or after laying and move elsewhere (Hogstad 1982).

Unlike $F$. montifringilla, the three "groundforaging" species E. schoeniclus, A. trivialis, and $L$. svecica all correlate positively and significantly with the appearance of the Epirrita caterpillars with a time lag of two years. This indicates that the rich supply of larvae increases the reproductive rate, which is followed by a bird density increase two years later when the surviving young birds may return and breed. A.trivialis shows the strongest reaction and also correlates significantly with the caterpillar abundance of the previous season (a time lag of only one year).

C. flammea is included in Table 9 because it is the only species showing an exclusively negative, albeit insignificant, relation to the appearance of the caterpillars, a fact that also holds true after allowance was made for the effect of the mean June and July temperatures. This general tendency may be a consequence of the possible outbreak-induced deterioration of the seed-producing vegetation. $C$. flammea is a granivorous bird that feeds its young with various seeds to a great extent (Enemar \& Nyström 1981).

In summary, the bird community density generally shows only a weak reaction to the Epirrita outbreaks. The prime responder is $F$. montifringilla, which shows increased density not only during the years of mass occurrence, but also one season in advance. The fact that most species seem to be unaffected suggests that possible negative consequences of the grazing larvae should be considered when evaluating the effect of the additional food supply that is represented by the caterpillars themselves.

Positive correlations between the abundance of lepidopteran caterpillars and the density and reproductive rate of passerine species have been established elsewhere in forests other than the subalpine variety (e.g. Morris et al. 1958, Zach \& Falls 1975, Holmes et al. 1986, Crawford \& Jennings 1989, Tomialojc \& Wesolowski 1990). Moreover, certain species are reported to appear in the study plots only during the outbreak years (Holmes \& Sherry 2001). As expected, experiences differ as to the extent and duration of the response in the investigated communities. In general, the community density does not significantly correlate with the appearance of the caterpillars. As a rule, a more or less clear response is restricted to only a few species populations. However, Wesolowski \& Tomialojc (1997) conclude that most insectivorous species in BNP do not vary in line with the fluctuations in caterpillar occurrence and suggest that other factors have a more important influence on the bird numbers. Moreover, the seasons with low caterpillar density do not necessarily mean a shortage of food for the breeding birds. This is similar to the situation in the subalpine birch forests. On the other hand, low larval occurrence can be indicative of a shortage of food in the Hubbard Brook study plots (Holmes 1988, Holmes et al. 1991, Holmes \& Sherry 2001). Bird fluctuations coincided with the actual caterpillar density or were significantly correlated with that of the previous season, even at low (normal or so-called endemic) larval abundance.

\section{The relations between the density fluctuations of the species}

A general view of the correspondence between the species fluctuations has been obtained by calculating the correlation coefficients for all combinations of species pairs. The 20 passerines that have been present in the study area for 32 seasons or more give rise to 190 coefficients, of which 151 are positive and only 39 negative, thus indicating an overwhelming tendency towards co-variation between the fluctuation patterns of these species. However, only 50 coefficients are significant at the $5 \%$ level, 46 of which are positive. In the case that all species populations fluctuate independently of each other, 10 coefficients at the $5 \%$ level of significance, could nonetheless be expected to appear, five of 
them positive. As there are in fact significantly more positive than negative correlations in the study area $\left(\chi^{2}=12.8, p<0.001\right)$ it appears justified to conclude that the fluctuation patterns of many species have a tendency to co-vary. In fact, all 20 species co-varied significantly with at least one community member. In contrast, there are only four significant negative correlations, which means that species pairs with reversed fluctuation patterns are not statistically established as a normal occurrence in the studied community.

In this regard, the bird community of a primeval deciduous forest (BNP) in Poland resembles our community to a surprisingly large extent (Wesolowski \& Tomialojc 1997). Pair-wise comparisons of 26 species of which all but three were passerines resulted in $27.4 \%$ significant positive correlation coefficients, which is very close to our figure $(24.2 \%)$. Significant negative correlations were extremely rare in both investigations, amounting to between $2 \%$ and $4 \%$.

The variance ratio V (Järvinen 1979) was calculated and applied in the analysis of the fluctuation patterns of the first 20 seasons (1963-1982) (Enemar et al. 1984). Although the V-test has been questioned by James \& Boecklen (1984), it is used here for comparison only and "as a descriptor of species patterns "(Schluter 1984). The first 20 seasons gave rise to a $\mathrm{V}$-value of 0.44 , i.e. well below unity, which indicates that the fluctuation patterns of the species populations tend to co-vary rather than the opposite. The succeeding 17 seasons accentuated this tendency by reducing the ratio to 0.30 for that period, resulting in a V-value of 0.40 for the entire 37 -year period. Obviously many species pairs or groups in the community share common features in their fluctuation patterns.

The degree of covariation between the fluctuation patterns of the species populations and groups can be investigated by carrying out a cluster analysis resulting in a so-called dendrogram (Cody 1974). This was done for the 18 (1965-1982) of the 20 years of our project (Enemar et al. 1984). The dendrogram displayed three distinct clusters of species. The species were mainly assorted in the clusters according to their different migration strategies, one group (A) was made up of tropical migrants (T-species), while two groups comprised short-distant migrants (Sspecies), of which one contained those species with irruptive migratory behaviour (B) and the other the remaining two short-distance and one long-distance migrant, all "ground-dwellers" in the breeding area (C). The interpretation of the dendrogram was that the annual density values in the breeding area are
Figure 11. Proximity matrices showing the correlation between pairs of the thirteen most abundant species as regards density fluctuations in the study area. Squares with significant correlation coefficients $(p<0.05)$ are shaded. The species are included in the matrices in the same order as in the dendrogram published by Enemar et al. (1984), which was based on 18 of the first 20 seasons in the study area. The top matrix corresponds to the dendrogram (1965-1982), while the bottom matrix shows the correlation coefficients of the total project period (1963-1999). The upper matrix displays three aggregations of significant coefficients; a large one in the upper section corresponding to cluster A in the dendrogram (longdistance migrants, with the short-distance migrantnT. philomelos as the exception), and two smaller ones, corresponding to the cluster $\mathrm{B}$ and cluster $\mathrm{C}$ of the dendrogram, the latter in the bottom right-hand section. Clusters $\mathrm{B}$ and $\mathrm{C}$ represent short-distance migrants with the long-distance migrantn $L$. svecica as the only exception. The bottom matrix shows that clusters $\mathrm{A}$ and $\mathrm{C}$ persist even with the addition of the first two and the last 17 years, whereas the presence of cluster B has declined markedly.

Rutdiagram som visar styrkan i samvariationen mellan de 13 vanligaste arternas tätheter i fjällbjörkskogen. Ju högre siffran är, desto mer sammanfaller fluktuationsmönstren för de båda arter som "möts" $i$ en given ruta. Skuggade rutor anger en statistiskt säkerställd samvariation. Av alla artpar är det björktrast/rödvinge-paret (T. pilaris/T. iliacus) som uppvisar den största likheten $i$ antalsvariationen mellan säsongerna. Det övre rutdiagrammet gäller perioden 1965-1982, det undre hela projektperioden 1963-1999. De skuggade, "säkra" rutorna är grupperade med den största ansamlingen i den övre delen (A), vars arter tenderar att skilja sig från de övriga $i$ hur de varierar. Bortsett från den översta arten (taltrasten) ingår endast tropikflyttare i gruppen, nämligen (i ordning uppifrån) lövsångare, trädgårdssångare, svartvit flugsnappare, rödstjärt och trädpiplärka. Troligen har just de gemensamma strapatserna och förlusterna under den långa flyttningen och $i$ det avlägsna övervintringsområdet påverkat fluktuationsmönstren $i$ samordnande riktning för dessa arter och det med ett resultat som skiljer sig från vad kortflyttarna uppvisar. De övriga två mindre grupperna (B och $C$ ) består med undantag för blåhaken av kortflyttare, nämligen först björktrast, rödvingetrast, bergfink och gråsiska, samt nederst järnsparv, blåhake och sävsparv. Det undre diagrammet visar att grupperingen av arterna på basis av likheten ifluktuationsmönstren $i$ stort sett består efter ökningen av antalet undersökta år, dock med undantag för gruppen B som blivit otydlig och inte längre övertygar. 
Turdus philomelos

0,82 Phylloscopus trochilus

\begin{tabular}{|c|c|c|c|}
0,72 & 0,67 & \multicolumn{2}{c}{ Sylvia borin $\quad$ A } \\
\hline 0,58 & 0,69 & 0,29 & Ficedula hypoleuca \\
\hline & & &
\end{tabular}

\begin{tabular}{l|l|l|l|l}
0,38 & 0,55 & 0,26 & 0,34 & Phoenicurus phoenicurus
\end{tabular}

$1965-1982$

\begin{tabular}{l|l|l|l|l|l}
0,44 & 0,54 & 0,56 & 0,12 & 0,59 & Anthus trivialis
\end{tabular}

\begin{tabular}{l|l|l|l|l|l|l|}
0,48 & 0,54 & 0,22 & 0,41 & 0,02 & $-0,08$ & Turdus pilaris \\
\hline
\end{tabular}

\begin{tabular}{l|l|l|l|l|l|l|l}
$\mathbf{0}, 48$ & 0,62 & 0,28 & 0,53 & 0,29 & $-0,04$ & 0,85 & Turdus iliacus
\end{tabular}

B

\begin{tabular}{l|l|l|l|l|l|l|l|l|}
0,12 & 0,27 & $-0,12$ & 0,05 & 0,34 & 0,04 & 0,40 & 0,53 & Fringilla montifringilla
\end{tabular}

\begin{tabular}{lll|l|l|l|l|l|l|l|}
$-0,08$ & $-0,06$ & $-0,30$ & 0,10 & 0,02 & $-0,49$ & 0,32 & 0,35 & 0,19 \\
\hline
\end{tabular}

\begin{tabular}{|c|c|c|c|c|c|c|c|c|c|c|c|c|}
\hline 0,43 & 0,28 & $-0,02$ & 0,17 & 0,27 & 0,14 & $-0,05$ & 0,12 & 0,39 & $-0,10$ & Prunella & modulari & \\
\hline 0,14 & 0,06 & $-0,33$ & 0,02 & 0,14 & $-0,01$ & $-0,07$ & $-0,05$ & 0,16 & 0,18 & 0,73 & Luscinia & svecica \\
\hline 0,24 & 0,01 & $-0,11$ & 0,03 & $-0,02$ & 0,06 & $-0,13$ & $-0,13$ & 0,14 & $-0,23$ & 0,79 & $0,59 \mathrm{E}$ & Emberiza \\
\hline
\end{tabular}

Turdus philomelos

\begin{tabular}{|c|c|c|c|c|c|c|c|c|c|c|c|c|}
\hline 0,54 & \multicolumn{3}{|c|}{ Phylloscopus trochilus } & \multirow[b]{2}{*}{ A } & & & & & & & & \\
\hline 0,67 & 0,22 & \multicolumn{2}{|c|}{ Sylvia borin } & & & & & & & & & \\
\hline 0,60 & 0,33 & 0,37 & Ficedula & hypolet & uca & & & & & & & \\
\hline 0,41 & 0,41 & 0,22 & 0,50 & Phoenic & urus pho & oenicurus & & & & 1963 & -19 & 99 \\
\hline 0,38 & 0,44 & 0,35 & 0,40 & 0,45 & Anthus & trivialis & & & & & & \\
\hline 0,24 & 0,60 & $-0,11$ & 0,12 & 0,06 & 0,08 & Turdus & pilaris & & & & & \\
\hline 0,33 & 0,51 & 0,08 & 0,31 & 0,12 & 0,13 & 0,79 & Turdus & iliacus & & B & & \\
\hline$-0,03$ & 0,23 & $-0,19$ & 0,08 & 0,10 & 0,05 & 0,27 & 0,38 & Fringilla & montifr & ingilla & & \\
\hline$-0,02$ & 0,03 & $-0,22$ & $-0,02$ & $-0,11$ & $-0,25$ & 0,29 & 0,38 & 0,11 & Cardueli & is flamme & & \\
\hline 0,56 & 0,29 & 0,12 & 0,16 & 0,00 & 0,09 & 0,16 & 0,30 & 0,14 & 0,10 & Prunella & modular & aris \\
\hline 0,24 & 0,23 & $-0,17$ & 0,18 & 0,07 & 0,19 & 0,34 & 0,36 & 0,11 & 0,20 & 0,66 & Luscinia & svecica \\
\hline 0,36 & 0,31 & 0,01 & 0,27 & 0,16 & 0,47 & 0,27 & 0,30 & 0,02 & 0,02 & 0,58 & 0,63 & Emberiza \\
\hline
\end{tabular}


strongly affected by the survival rate in the wintering area and during migration. Therefore, the breeding densities of species with common migration and wintering behaviour should show similar fluctuation patterns.

The result of a different co-variation analysis based on the 37-year data sample is presented in the "proximity matrix" of Figure 11. A cluster analysis was abandoned due to its tendency to exaggerate minor differences in the correlation coefficients when "clustering" pairs of species or species groups. The "proximity matrix" illustrates the complexity of the calculated relations between the fluctuation patterns of the species in a more realistic way. For comparative purposes, the matrix was based on the proportional density values of the same species as in the 18-year dendrogram, and these are listed in that same order. In the matrix, the squares with significant correlation coefficients show a grouping approximately corresponding to the $\mathrm{A}, \mathrm{B}$, and $\mathrm{C}$ migration clusters of the dendrogram. The latter has been "translated" into a corresponding proximity matrix to facilitate comparison (Figure 11). The general pattern of clusters persists even after the addition of the post-1982 period. The group C species are exactly the same, whereas the similarity between the tropical group A of the 18 and 37-year periods, although obvious, is less definite. Group B is less interesting in both analyses because it consists of rather loosely related species with the exception of the two thrush species T. iliacus and T. pilaris, which showed the strongest co-variation of all species pairs in both analyses. The two "rebellious" species are the S-species T. philomelos and the T-species $P h$. trochilus. T. philomelos is still closely linked to group A, i.e. it remains a tropical migrant in respect of its fluctuation pattern. Ph. trochilus has come closer to group B over the last 17 years, resulting in its highest correlation coefficients with the thrush species (Figure 11). Nevertheless, the information contained in the Figure 11matrix does not seem to provide sufficient grounds for entirely abandoning the hypothesis that the migration strategy is a significant factor influencing the pattern of the bird density variation in our study area.

Many studies have documented the fact that changes in winter survival rates are followed by changes in the breeding density (e.g. Fretwell 1972, Newton 1998). It is therefore not surprising that the fluctuation patterns of the species in a study area tend to be grouped together according to their wintering and migratory habits. Over a 40-year period, the bird community of a small study plot in southern Sweden showed a distinct division into two "fluctuation groups", mainly consisting of tropical and short-distance migrants, respectively (Enemar et. al. 1994). However, other investigations have revealed little or no synchronic fluctuations related to common wintering areas. This may be at least partly due to the fact that the time-scale of the investigations has not been long enough to compensate for various background disturbances (for references, see Enemar et al. 1994). It is interesting to note that, based on their 20-year census work in BNP, Wesolowski \& Tomialojc (1997) did not find a corresponding grouping of population fluctuations.

\section{Fluctuations of the short-distance versus long- distance (tropical) migrants}

In the European passerine communities, the proportion of tropical migrants (T-species) shows an increasing gradient northward (e.g. Herrera 1978). Herrera, with reference to Moreau (1952), includes all species that are resident or that winter within the Western Palaearctic in one and the same category, that of resident species, despite the fact that many of them are short-distance migrants (S-species). True passerine residents wintering in the birch forests of our study area are few and occur irregularly. Flocks of $C$. flammea forage there in winters following summers with rich birch mast seeding and scattered pairs of 'Parus montanus have been observed. The Sspecies are the first to arrive and settle in the springtime and, according to Herrera (1978), the later arriving T-species then repopulate the area in numbers that are determined by the amount of space and resources not exploited by birds already present. Therefore, the number of settling T-species depends on, among other things, the winter survival of the Sspecies. The proportion between the densities of the two species groups may of course vary between seasons, perhaps partly in an opposing manner. Herrera's model has been studied and verified by O'Connor(1981), Berthold(1990), Morozov (1993), and Enemar et al. (1994). Mönkkönen et al. (1990) and Timonen et al. (1994) have questioned it, as did Wesolowski \& Tomialojc (1997) who found that its validity could change from one decade to another.

The proportion of T-species has remained close to 40 percent of the total community at Ammarnäs over the 37 years, and their total density has been about half that of the community. The seasonal densities of the two species groups are positively and significantly correlated in our study area (Figure 12). The test 


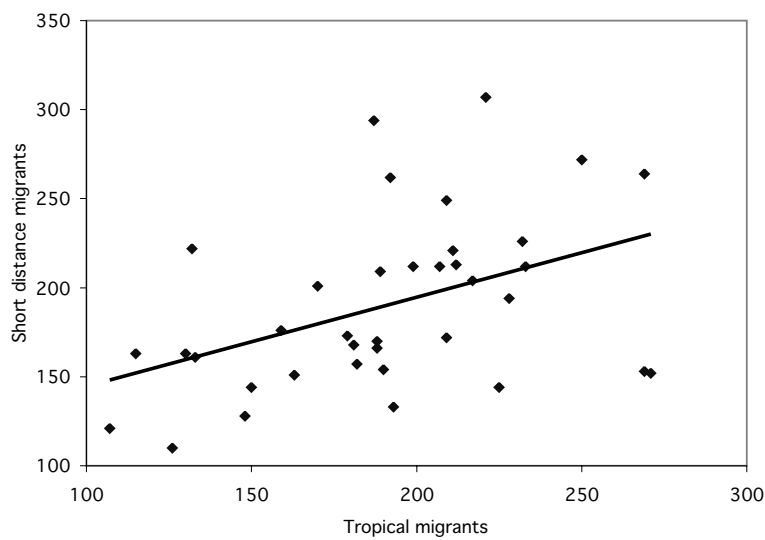

Figure 12. The relation between the derived densities of the six most abundant tropical migrants and the eight short-distant migrants during the 37 breeding seasons $(y=0.5 x+94.4, r=$ $0.44, \mathrm{p}<0.01)$.

Diagram som redovisar sambandet mellan de härledda tätheterna för tropikflyttarna (vågräta axeln) à ena sidan och kortflyttarna (lodräta axeln) å den andra under de 37 åren. Linjen visar genomsnittligt att om ena artgruppen är talrik så är också den andra det.

included all species with a mean density index of three or more, making up $95.3 \%$ of the total community.

This relation between the T- and S-species is quite contrary to that found in the bird community of Birdsong Valley in southernmost Sweden where the species groups showed a significant negative correlation over 40 years (Enemar et al. 1994). However, the comparison may be inaccurate because the investigation was confined to a small and isolated study plot with, on average, 124 territories, and, moreover, the density figures only represented mapped territories. The latter may better reflect competitive effects than is the case with the density indices of this study, which also includes nonterritorial birds from the line transects. Therefore, the number of mapped territories in our study plots has been subjected to the same correlation analysis. The result does not differ greatly from that based on the derived densities. The proportion of the T-species density $(31 \%)$ and the regression coefficient $(b=$ $0.44, r=0.45, p<0.05$ ) are somewhat lower, although both reductions are far from being statistically significant. Herrera's hypothesis is obviously not valid in all respects in our subalpine birch forest. The concordant fluctuation trends of the T- and S-species are indicative of the unsaturated state of the habitat as suggested by Enemar et al. (1984). In other words, the habitat is probably not populated densely enough to create the competitive situation on which Herrera's interpretations are based.

\section{Long-term trends versus short-term fluctuations}

Böhning-Gaese et al. (1994) investigated the relation between the short-term fluctuations and the longterm trends of pairs of bird species populations using the data collected by the North American Breeding Bird Survey. They derived two dissimilarity indices of each species pair, one based on the difference between the regression coefficients of the long-term population trends, and one for the annual fluctuations calculated for each species pair based on the correlation coefficient of the residuals from the long-term trends. The indices vary from 0 (totally similar regressions) to 2 (totally dissimilar fluctuations). By comparing the two indices BöhningGaese et al. (1994) found, among other things, that two co-existing species exhibiting similar shortterm fluctuation patterns could nevertheless have opposing long-term population trends, and vice versa. They concluded that investigations over restricted time-scales should not be used to predict the longterm trends, a well-founded warning, as the vast majority of bird census investigations have been carried out on small temporal scales.

Wesolowski \& Tomialojc (1997) found that the dissimilarity indices of the long-term trends and short-term fluctuations of their species pairs were not at all correlated $(\mathrm{r}=0.004, \mathrm{n}=325)$, thus supporting the results of Böhning-Gaese et al.(1994). When applied to the 20 passerines in our study area the test resulted in the same information $(r=0.001$, $\mathrm{n}=190$ ). The matrices show that most values of both dissimilarity indices are less than 1 , the mean index of the long-term trends being $0.2 \pm 0.18$, and that of the annual fluctuations $0.8 \pm 0.20$. Thus both indices give the impression of a bird community with a remarkable concordance in the dynamics of the different species populations. As shown above, this does not mean that the two indices are correlated. Two species may have quite different long-term trends despite exhibiting similar fluctuation patterns.

\section{Examples of strengths and weaknesses of long-term} bird census work

One may well ask whether the annual census work in the subalpine birch forest has provided any new and reliable information on important aspects on its bird community exclusively due to its time span of nearly four decades. If we had not believed in the promising 
potential of our fieldwork, all project members would no doubt have opted to become monks or molecular biologists instead, to quote Wiens (1981). However, we were confident that a long-term series of census work of consistent quality would help to avoid wrong conclusions due to census periods of insufficient duration and to identify qualities and correlations that are otherwise difficult to recognise due to the unavoidable "background noise" caused by e.g. random events, unusual occurrences and census errors. Our expectations have been reasonably fulfilled as indicated by the following three selected examples. A fourth example is added illustrating that even a long-term series can provide totally exceptional information.

1) The passerine bird community is at equilibrium in the sense that its bird density trend has not changed over the 37-year period. This does not exclude considerable fluctuations between seasons, including also fairly long-term trends within the period, such as the continuous community density decline from about 1970 to 1980 , as illustrated by the moving 10year density means (Figure 10). Had the project terminated in 1984 as a 22-year project, even then deemed a long-term one, the most obvious suggestion would have been that long-term environmental deterioration was in progress with negative consequences for the birds. However, the continuation of the census programme showed that the community recovered and once again attained "original" density levels.

2) The fluctuations of the total community are significantly correlated with those of the environmental June and July temperature means, when certain time lags are considered (Table 6). This relation is also clearly demonstrated by the moving 10 -year means of the June temperature during the first two thirds of the project period (Figure 10). Thanks to the prolongation of the fieldwork, one is saved from believing that the correlation is axiomatic. The last third of the period shows that other longterm factors might overshadow the effect of those correlated to the long-term temperature fluctuations in June.

3) One of the most exciting prospects of the longterm project was to collect sufficient data to permit successful analyses of the bird community reactions to the cyclic outbreaks of the autumnal moth Epirrita autumnata. To our surprise, the dynamics of the community is only weakly affected, and the reaction is mainly due to the abundant $F$. montifringilla, the prime responder to the mass caterpillar occurrences. The outbreaks probably increased the reproductive rate of only three ground-nesting species as indicated by a population increase two years later. Thanks to the consistency of the long-term results in these matters, one dares to suggest that the nutritional capacity of the habitat is so good that the mass appearance of the caterpillars does not have much impact on the majority of the species.

4) How long, then, is a long-term census? Several authors (e.g. Wiens 1984, Calder III 1984, Tomialojc \& Wesolowski 1994) have commented on this
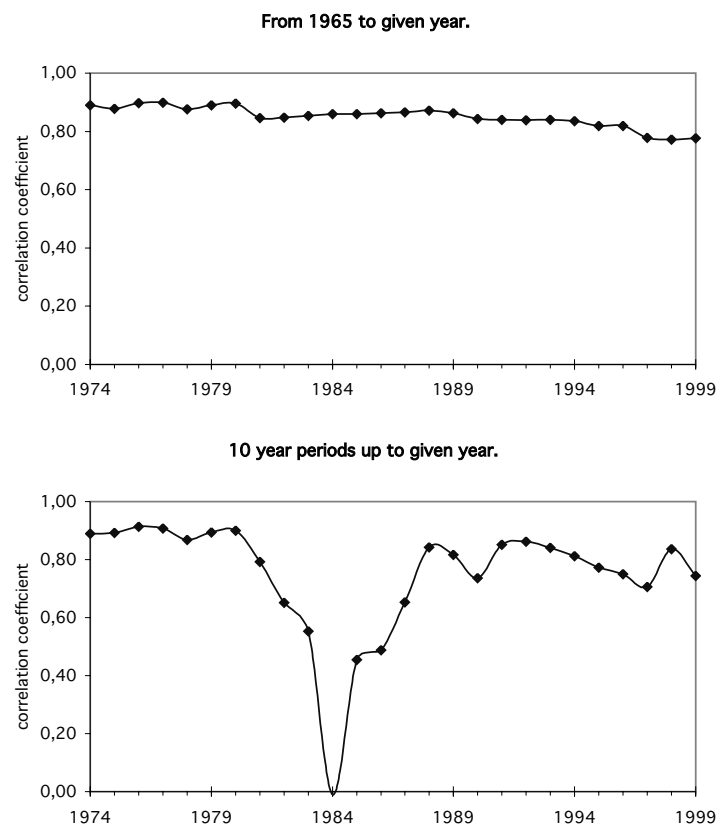

Figure 13. Correlations between the derived densities of Turdus pilaris and T. iliacus for various time spans. The top diagram shows the correlation coefficients of the 26 successively increasing periods starting with the 10 -year period from 1965-1974 and ending with the 35-year period from 19651999. The bottom diagram shows the correlation coefficients of the 26 individual 10-year periods, starting with the period from 1965-1974 and ending with the period from 1990-1999. Diagrammen visar sambandet mellan björktrastens och rödvingetrastens beståndsvariationer för olika tidsperioder. Korrelationskoefficienten anges på vänstra axeln. Ju högre värdet $\ddot{a}$, desto mer likartat varierar de båda arterna under den angivna årsföljden. Det övre diagrammet visar hur koefficienten ligger på ungefär samma höga nivå, då den testade perioden ökar med ett år i sänder från 10 år (1965-1974) fram till 35 år (1965-1999). Det undre diagrammet visar hur sambandet varierar för de 26 enskilda 10-årsperioderna, från den första 1965-1974 till den sista 1990-1999. Här är variationen större med en 10-årsperiod (1975-1986), då inget som helst samband fanns mellan de båda arternas sätt att fluktuera. 
question. There is of course no definite answer. A 10year period has often been considered sufficiently long-term. However, the following example illustrates how even a 10 -year period can provide a totally exceptional result in relation to what should be considered as "normal".

Needless to say, long-term census work is required to identify co-varying species pairs, such as the $T$. pilaris and T. iliacus population densities. As shown in Figure 13, the correlation coefficient is about 0.9 for the 10-year period 1965-1974, after which it remains high and fluctuates between 0.8 and 0.9 for each additional year up to the end of the 37 -year period in 1999. However, the correlation coefficient for each separate 10 -year period partly provides quite a different pattern (Figure 13). The initially high coefficients show a decrease beginning with the period ending in 1980 and falling to an all time low four periods later. It returns to the higher level after another four periods. It is remarkable that the minimum coefficient is close to zero. This means that the two species fluctuate quite independently during the period 1975-1984. Had the census work been restricted to that specific ten-year period, the generally very strong relation between the two thrush species would have remained undetected, not even suspected.

Concluding hypothesis: Why does the rich subalpine birch forest remain unsaturated?

Enemar et al. (1984) suggested that the birch woods of our study area are unsaturated, i.e. there are on average fewer breeding birds than the habitat could support. A number of observations and results indicating this state were listed. The experiences of the continued investigations in the area have provided no reason to abandon the "unsaturation hypothesis". Instead, it has been strengthened by new information such as the concordant fluctuations of the tropical and the short-distant migrants and the density response to increased mean temperature in June, both indicating a rather "competition-free" state in the habitat. The question now is why the unsaturated state seems to be so consistently maintained, perhaps being one of the principal and distinctive characteristics of this northern bird community.

A possible explanation could be that the northern habitat represents an area of bird community sink. This would mean that the bird numbers are largely maintained by an immigrant surplus from outside the subalpine zone but that this immigration is, on average, too limited to saturate the habitat. However, this view is contradicted by the fact that the community density shows no relation to the temperature of the current season.

The habitat may well be more productive and richer from the birds' point of view than what the density figures suggest. This assumption is supported by the fact that most species densities seem to remain largely unaffected by the cyclic mass occurrences of the Epirrita caterpillars indicating that the habitat is richly and more or less permanently supplied with other food sources. The reproductive efficiency of the birds is probably considerable as indicated by the clutch sizes, which coincide with the well-known latitudinal trend (Lack 1968), and by the egg sizes (nine passerine species investigated), which are equal to or larger than those in Central Europe (Enemar \& Arheimer 1999). Thus there is no reason to suspect the presence of a failing reproductive capacity that could contribute to a state of bird community sink. Instead, the available information indicates that the community is self-supporting and is even able to respond with a density increase to high June temperatures (see above). Nonetheless, the unsaturated state of the community seems to prevail in the long run.

An explanation may be related to the sometimes pronounced instability characterizing the northern bird communities. It can be demonstrated by comparing the community fluctuations in our study area with that of rich deciduous woods in more southerly regions, such as in BNP in Poland (Wesolowski \& Tomialojc 1997, Wesolowski et al. 2002). The span between the minimum and maximum densities is three times larger at Ammarnäs than in $\mathrm{BNP}$ and the maximum increase between two successive seasons is four times greater. It has been suggested that this difference is a consequence of the unpredictability of the weather in the north, where extremes are more disastrous for the breeding activities than in the south (Järvinen 1979). Moreover, due to the short breeding season in the north there is less time available for laying replacement clutches, especially when the first breeding attempt has failed at a relatively advanced stage. Thus, the breeding acitivities in the northern bird community are probably so frequently disturbed by poor weather conditions with negative effects on the reproduction that the average bird density is prevented from approaching the carrying capacity of the habitat. We suggest, therefore, that the weather factor is important in maintaining the apparent unsaturated state of the bird community in our study area. One can speculate on whether the global warming will induce smoother 
fluctuation patterns and increasing bird densities there in the long run.

\section{Acknowledgements}

The fieldwork has been supported by grants from the Swedish Natural Science Research Council (NFR) during most of the first 25 years. Financial support has been received from time to time from the Royal Swedish Academy of Sciences, the Royal Society of Arts and Sciences in Göteborg, the Carl Trygger Foundation and the Seth M. Kempe Memorial Foundation. Our thanks are due to our fellow field workers from the LUVRE project (see Tables 2, 3, and 4). We also wish to thank Tomasz Wesolowski, Scott Sillett and Åke Lindström for helpful criticism much improving an earlier version of this paper, and Gullvi Nilsson for her assiduous efforts to render the English readable and Erik Nyholm for providing us with temperature data.

\section{References}

Abbott, I. 1978. Factors determining the number of land bird species on island around south-western Australia. Oecologia 33: 221-233.

Andersson, G. \& Jonasson, J. Å. 1980. Relative abundance of insects on mountain birch at Ammarnäs, Swedish Lapland. Entomol. Tidskr. 101: 61-69. (In Swedish with summary in English.)

Anon. 1970. Recommendations for an international standard for a mapping method in bird census work. Pp. 49-52 in Bird census work and environmental monitoring (Svensson, S. ed.). Bull. Ecol. Res. Comm. Nr 9. Lund.

Arheimer, O. 1978. Choice of food and rate of feeding young in the Redwing Turdus iliacus in a subalpine birch forest at Ammarnäs in Swedish Lapland. Anser suppl. 3:31-46. (In Swedish with summary in English.)

Bengtsson, J., Baillie, S.R. \& Lawton, J. 1997. Community variability increases with time. Oikos 78: 249-256.

Berthold, P. 1990. Die Vogelwelt Mitteleuropas: Entstehung der Diversität, gegenwärtige Veränderungen und Aspekte der zukünftigen Entwicklung. Verh. Dtsch. Zool. Ges. 83: 227-244.

Blondel, J., Ferry, C. \& Frochot, B. 1981. Point counts with unlimited distance. Studies in Avian Biology No. 6: 414420.

Böhning-Gaese, K., Taper, M.L. \& Brown, J.H. 1994. Avian community dynamics are discordant in space and time. Oikos 70: 121-126.

Bonnier, G. \& Tedin, O. 1940. Biologisk variationsanalys. Bonniers, Stockholm.

Calder, W.A.III 1984. How long is a long-term study? Auk 101:893-894.

Cody, M. L. 1974. Competition and structure of bird communities. Princeton University Press, New Jersey.

Crawford, H.S. \& Jennings, D.T. 1989. Predation by birds on spruce budworm Choristoneura fumiferana: functional, numerical, and total responses. Ecology 70: 152-163

Diamond, J.M. \& May, R.M. 1977. Species turnover rates on islands: dependence on census intervals. Science 197: 266270.

Enemar, A. \& Arheimer, O. 1999. Egg sizes of nine passerine bird species in a subalpine birch forest, Swedish Lapland. Ornis Svecica 9: 1-10.

Enemar, A., Cavallin, B., Nyholm, E., Rudebeck, I. \& Thorner, A.M. 1994. Dynamics of a passerine bird community in a small deciduous wood, S Sweden, during 40 years. Ornis Svecica 4: 65-104.

Enemar, A., Höjman, S.-G., Klaesson, P. \& Nilsson, L. 1976. The relationship between census results and the breeding populations of birds in subalpine birch forests. Ornis Fennica 53: 1-8.

Enemar, A., Klaesson, P. \& Sjöstrand, B. 1979. Accuracy and efficiency of mapping territorial Willow Warblers Phylloscopus trochilus: a case study. Oikos 33: 176-181.

Enemar, A., Nilsson, L. \& Sjöstrand, B. 1984. The composition and dynamics of the passerine bird community in a subalpine birch forest, Swedish Lapland. A 20-year study. Ann. Zool. Fennici 21: 321-338.

Enemar,A. \& Nyström, B. 1981. Population fluctuations, food and breeding of the Redpoll Carduelis flammea in a mountain birch forest, Swedish Lapland. Vår Fågelvärld 40: 409-426. (In Swedish with summary in English.)

Enemar, A. \& Sjöstrand, B. 1967. The strip survey as a complement to study area investigations in bird census work. Vår Fågelvärld 26: 111-130.

Enemar, A. \& Sjöstrand, B. 1970. Bird species densities derived from study area investigations and line transects. Pp. 33-37 in Bird census work and environmental monitoring (Svensson, S. ed.). Bull. Ecol. Res. Comm. No 9. NFR, Stockholm.

Enemar, A., Sjöstrand, B. \& Svensson, S. 1978. The effect of observer variability on bird census results obtained by a territory mapping technique. Ornis Scand. 9: 31-39.

Franklin, J.F. 1989. Importance and justification of long-term studies in ecology. In Longterm studies in ecology: applications and alternatives (Likens. G.E. ed.). Springer-Verlag, New York.

Fretwell, S.D. 1972. Populations in a seasonal environment. Princeton University Press.

Glutz von Blotzheim, U. N. \& Bauer, K. M. 1985-1997. Handbuch der Vögel Mitteleuropas. Bd 10-14. AULAVerlag, Wiesbaden.

Golovatin, M.G. 2002. Population dynamics of passerines in the subarctic conditions. Avian Ecol. Behav. 8: 23-34.

Hanhimäki, S. \& Senn, J. 1992. Sources of variation in rapidly inducible responses to leaf damage in the mountain birchinsect herbivore system. Oecologia 91: 318-331.

Haukioja, E. 1980. On the role of plant defences in the fluctuation of herbivore populations. Oikos 35: 202-213.

Haukioja, E. \& Hanhimäki, S. 1985. Rapid wound-induced resistance in white birch (Betula pubescens) foliage to the Epirrita autumnata: a comparison of trees and moths within and outside the outbreak range of the moth. Oecologia 65: 223-228.

Herrera, C.M. 1978. On the breeding distribution patterns of European migrant birds: MacArthur's theme re-examined. Auk 95: 496-509.

Hogstad, O. 1969. Breeding bird populations in two subalpine 
habitats in the middle of Norway during the years of 1966 1968. Nytt. Mag. Zool. 17: 81-91.

Hogstad, O. 1975. Structure of small passerine communities in subalpine birch forests in Fennoscandia. Pp. $94-104$ in Fennoscandian tundra ecosystems. Part 2: Animals and systems analysis (Wielgolaski, F.E. ed.). Springer-Verlag, Berlin-Heidelberg-New York

Hogstad, O. 1982. Seasonal and daily weight variation of adult Bramblings Fringilla montifringilla during the breeding season. Fauna norv. Ser. C, Cinclus 5: 59-64.

Hogstad, O. 1985. Annual variation in mean body size of a Brambling Fringilla montifringilla population. Ornis Fennica 62: 13-18.

Hogstad, O. 1988. Foraging pattern and prey selection of the breeding Bramblings Fringilla montifringilla. Fauna norv. Ser. C, Cinclus 11: 27-39.

Hogstad, O. 1996. Morphological changes of Epirrita autumnata Bkh. and Operophtera brumata (L.) (Lep., Geometridae) during a mass outbreak in a subalpine birch forest in Cenral Norway. Fauna norv. Ser. B 43: 47-57.

Hogstad, O. 2000. Fluctuation of a breeding population of Brambling Fringilla montifringilla during 33 years in a subalpine birch forest. Ornis Fennica 77: 97-103.

Holmes, R.T. 1988. Community structure, population fluctuations, and resource dynamics of birds in temperate deciduous forests. Acta XIX Congr. Int. Ornithol.: 1318-11327.

Holmes, R.T. \& Sherry, T.W. 2001. Thirty-year bird population trends in an unfragmented temperate deciduous forest: importance of habitat change. Auk 118: 589-609.

Holmes, R.T., Sherry, T.W. \& Sturges, F.W. 1986. Bird community dynamics in a temperate deciduous forest: Longterm trends at Hubbard Brook. Ecol. Monographs 56: $201-$ 220.

Holmes, R.T., Sherry, T.W. \& Sturges, F.W. 1991. Numerical and demographic responses of temperate forest birds to annual fluctuations in their food resources. Acta XX Congr. Int. Ornithol.: 1559-1567.

James, F.C. \& Boecklen, W.J. 1984. Interspecific morphological relationships and the density of birds. In Ecological communities: conseptual issues and the evidence (Strong, D.R. et al. eds.). Princeton University Press.

Järvinen, A. 1989. Geographical variation in temperature variability and predictability and their implications for the breeding strategy in the Pied Flycatcher Ficedula hypoleuca. Oikos 54: 331-336.

Järvinen, A. \& Pietiäinen, H. 1983.'The Bluethroat' Luscinia s. svecica population at Kilpisjärvi, Finnish Lapland: density, habitat selection, age structure and nesting success in 1981. Pp. 189-194 in Proc. Third Nordic Congr. Ornithol. Copenhagen.

Järvinen,A. \& Rajasärkkä,A. 1992. Population fluctuations in two northern bird communities: effects of habitat, migration strategy and nest-site. Ornis Fennica 69: 173-183.

Järvinen, A. \& Väisänen, R.A. 1984. Reproduction of Pied Flycatcher (Ficedula hypoleuca) in good and bad breeding seasons in a northern marginal area. Auk 101: 439-450.

Järvinen, O. 1979. Geographical gradients of stability in European bird communities. Oecologia 38: 51-69.

Järvinen, O. 1980. Dynamics of North European bird communities. Proc. $17^{\text {th }}$ Int. Ornithol. Congr. (Berlin) 1978: 770 776.

Jones, H.L. \& Diamond, J. 1976. Short-term-base studies of turnover in breeding bird populations on the California Channel Islands. Condor 78: 526-549.

Kaitaniemi, P., Ruohomäki, K., Tammaru, T. \& Haukioja, E. 1999. Induced resistance of host tree foliae during and after a natural insect outbreak. J. Anim. Ecol. 68: 382-389.

Kendeigh, S.C. 1982. Bird populations in east central Illinois: Fluctuations, variations, and development over a half-century. Illinois Biological Monographs 52. Univ. Illinois Press.

Klinckowström, A. 1909. En sommar i Frostviksfjällen. Fauna och Flora 4: 1-18, 53-70, 101-120.

Kullman, L. 1981. Some aspects of ecology of the Scandinavian subalpine birch forest belt. Wahlenbergia 7: 99-112. Umeå.

Lack, D. 1968. Ecological adaptations for breeding in birds. Methuen, London.

Lindström, §. 1987. Breeding nomadism and site tenacity of the Brambling Fringilla montifringilla. Ornis Fennica 64: $50-56$.

Lindström, Å., Enemar, A., Andersson, G., von Proschwitz, T. \& Nyholm, E. Density-independent reproductive output of an insectivorous bird in relation to the abundance of its cyclically appearing prey. MS

Martin, T.E. 1987. Food as a limit on breeding birds: a lifehistory perspective. Ann. Rev. Ecol. Syst. 18: 453-487.

McIntosh, R.P. 1995. H.A. Gleason's “individualistic concept" and theory of animal communities: a continuing controversy. Biol. Rev. 70: 317-357.

Merikallio, E. 1946. Über regionale Verbreitung und Anzahl der Landvögel in Süd- und Mittelfinnland, besonders in deren östlichen Teilen, im Lichte von quantitativen Untersuchungen. I und II Teil. Ann. Zool. Soc. Zool.-Bot. Fenn. Vanamo 12. N:o 1 und 2.

Mikkonen, A.V. 1983. Breeding site tenacity of the Chaffinch Fringilla coelebs and the Brambling F. montifringilla in northern Finland. Ornis Scand. 14: 36-47.

Mönkkönnen, M., Heller, P. \& Soppela, K. 1990. Numerical and behavioural responses of migrant passerines to experimental manipulation of resident tits (Parus ssp.): heterospecific attraction in northern breeding bird communities? Oecologia 85: 218-225.

Moreau, R.E. 1952. The place of Africa in the Palaearctic migration system. J. Anim. Ecol. 21: 250-271.

Morozov, N.S. 1993. Short-term fluctuations in a south-taiga bird assemblage: support for an "individualistic" view. Ornis Fennica 70: 177-188.

Morris, R.F., Cheshire, W.F., Miller, C.A. \& Mott, D.G. 1958. The numerical response of avian and mammalian predators during a gradation of the spruce budworm. Ecology 39: 487-494.

Newton, I. 1998. Population limitation in birds. Academic Press, San Diego \& London.

Noon, B.R., Dawson, D.K. \& Kelly, J.P. 1985. A search for stability gradients in North American breeding bird communities. Auk 102: 64-81.

Nyholm, N.E.I. 1981. Evidence of involvement of aluminium in causation of defective formation of eggshells and of impaired breeding in wild passerine birds. Environm. Res. 26: $363-371$.

Nyholm, N.E.I. 1986. Birth area fidelity and age at first breeding in a northern population of Pied Flycatcher Ficedula hypoleuca. Ornis Scand. 17: 249-252.

O'Connor, R.J. 1981. Comparisons between migrant and non- 
migrant birds in Britain. Pp. 157-195 in Animal Migration (Aidley, D.E. ed.). Cambridge University Press.

Ossipov, V., Haukioja, E., Ossipova, S., Hanhimäki, S. \& Pihlaja, K. 2001. Phenolic and phenolic-related factors as determinants of suitability of mountain birch leaves to an herbivorous insect. Biochem. Syst. Ecol. 29: 223-240.

Palmgren, P. 1930. Qantitative Untersuchungen über die Vogelfauna in den Wäldern Südfinnlands. Acta Zool. Fennica 7, pp. 1-218.

Rotenberry, J.T. \& Wiens, J.A. 1980. Temporal variation in habitat structure and shrub-steppe bird dynamics. Oecologia 47: 1-9.

Schluter, D. 1984. A variance test for detecting species associations, with some example applications. Ecology 65: 998-1005.

Selås, V., Hogstad, O., Andersson, G. \& von Proschwitz, T. 2001. Population cycles of autumnal moth, Epirrita autumnata, in relation to birch mast seeding. Oecologia, 129: 213-219.

Siivonen, L. 1948. Quantitative bird survey and the short-term fluctuations in numbers. Ornis Fennica 25: 37-56.

Silvola, T. 1967. Changes in the bird populations in Utsjoki, Finnish Lapland in 1961-1966, caused by mass-occurrence of the caterpillar Oporinia autumnata. Ornis Fennica 25: 65-67. (In Finnish with English summary.)

Suomela, J., Ossipov, V. \& Haukioja, E. 1995. Variation among and within mountain birch trees in foliage phenols, carbohydrates, and amino acids, and in growth of Epirrita autumnata larvae. J. Chem. Ecol. 21: 1421-1446.

Svensson, S., Carlsson, U.T. \& Liljedahl, G. 1984. Structure and dynamics of an alpine bird community, a 20-year study. Ann. Zool. Fennici 21: 339-350.

Svensson, S. \& Lindström, Å. 2002. Övervakning av fåglarnas populationsutveckling. Arsrapport 2002. Ekologiska institutionen, Lunds universitet, Lund.

Timonen, S., Mönkkönen, M. \& Orell, M. 1994. Does competition with residents affect the distribution of migrant birds? Ornis Fennica 71: 55-60.

Tomialojc, L.\& Wesolowski, T. 1990. Bird communities of the primeval temperate forest of Bialowieza, Poland. Pp. 141165 in Biogeography and ecology of forest bird communities (Keast, A. ed.). SPB Academic Publishing bv. The Hague.

Tomialojc, L. \& Wesolowski, T. 1994. Die Stabilität der Vogelgemeinschaft in einem Urwald der gemässigten Zone: Ergebnisse einer 15jährigen Studie aus dem Nationalpark von Bialowieza (Polen). Ornithologische Beobachter 91: 73-110.

Underwood, A.J. 1986. What is a community? Pp. 351-367 in Patterns and processes in the history of life. (Raup, D.M. \& Jablonski, D. eds.). Springer-Verlag Berlin.

Virolainen, M. 1984. Breeding biology of the Pied Flycatcher Ficedula hypoleuca in relation to population density. Ann. Zool. Fennici 21: 187-197.

Weatherhead, P.J. 1986. How unusual are unusual events? American Naturalist 128: 150-154.

Wesolowski, T. \& Tomialojc, L. 1997. Breeding bird dynamics in a primaeval temperate forest: long-term trends in Bialowieza National Park (Poland). Ecography 20: 412-453.

Wesolowski, T., Tomialojc, L., Mitrus, C., Rowinski, P. \& Czeszczewik, D. 2002. The breeding bird community of a primaeval temperate forest (Bialowieza National Park, Pol- and) at the end of the $20^{\text {th }}$ century. Acta Ornithologica 37: $28-45$.

Wiens, J.A. 1977. On competition and variable environments. American Scientist 65: 590-597.

Wiens, J.A. 1980. Concluding comments: Are bird communities real? Proc. 17 $7^{\text {th }}$ Int. Ornithol. Congr. (Berlin) 1978: 1088-1089.

Wiens, J.A. 1981. Scale problems in avian censusing. Studies in Avian Biology No. 6: 513-521.

Wiens, J.A. 1984. Editorial. The place of long-term studies in ornithology. Auk 101: 202-203.

Wiens, J.A. 1989a. The ecology of bird communities. Vol. 1. Foundations and patterns. Cambridge University Press.

Wiens, J.A. 1989b. The ecology of bird communities. Vol 2. Processes and variations. Cambridge University Press.

Wiens, J.A., Addicot, J.F., Case, T.J. \& Diamond, J. 1986. Overview: The importance of spatial and temporal scale in ecological investigations. Pp. 145-153 in Community eco$\log y$ (Diamond, J. \& Case, T.J. eds.). Harper \& Row, New York.

Ytreberg, N. J. 1972. The stationary passerine bird populations in the breeding season, 1968-1970, in two mountain forest habitats on the west coast of southern Norway. Norw. J. Zool. 20: 61-89.

Zach, R. \& Falls, J.B. 1975. Response of Ovenbird (Aves: Parulidae) to an outbreak of the spruce budworm. Can. J. Zool. 53: 1669-1672.

\section{Sammanfattning}

\section{Inledning}

Ett omfattande inventeringsarbete i syfte att studera främst småfågelsamhällets sammansättning och fluktuationer i bl.a. fjällbjörkskog påbörjades 1963 i Ammarnäs-området i södra Lappland. Fältarbetet har sedan dess upprepats årligen (projektet LUVRE). I denna artikel presenteras vissa resultat, analyser och erfarenheter i övrigt, som införskaffats fram till århundradets slut, alltså omfattande en årsföljd om 37 år.

De första 20 åren av projektet har analyserats och publicerats tidigare (Enemar et al. 1984, utan svensk sammanfattning) och benämns i det följande " 20 årsuppsatsen". Den nu längre sviten av inventerade säsonger har gjort det möjligt att undersöka hur faktorer som väder och tillgång till föda påverkat småfågelbeståndet. Vädret kan växla oerhört både inom och mellan säsongerna i denna nordliga miljö. Därför har sambandet mellan temperaturen och fågeltätheten under häckningstiden granskats. Födotillgången ökar några år per decennium till överflödsnivåer genom de s.k. massutbrotten av fjällbjörkmätarlarver. Därför har även larvförekomsten inventerats inom projektet och därmed har dess eventuella påverkan på småfågelbestånden kunnat studeras. 
Det största problemet i samband med ett personalkrävande projekt av detta slag ligger naturligtvis i svårigheten att upprätthålla kontinuiteten. Statligt forskningsstöd med långa tidsperspektiv kan aldrig påräknas. LUVRE har dock lyckats hålla verksamheten igång av flera skäl. Projektet har minimerat alla formella bindningar till universitetsvärlden med allt vad denna medför av publiceringstvång, direktiv och trendföljsamhet. Nyfikenhet och intresse har varit drivkraften hos projektdeltagarna och detta i så hög grad att insatserna fullgjorts trots ofullständig eller ingen ersättning för resekostnader och traktamenten, allt under LUVRE-projektets uppfordrande motto: "Ingen biologisk observationsserie blir någonsin tillräckligt lång för att avbrytas."

\section{Fältarbetsområdet}

Inventeringsarbetet har utförts i $9 \mathrm{~km}^{2}$ fjällbjörkskog på sydsidan av lågfjällen Gaisatj och Valle nära byn Ammarnäs i södra Lappland (Figur 1). Skogen är mestadels av den rika typen (“ängsbjörkskog") (Figur 2) och har inte märkbart ändrat karaktär under de 37 åren (Figur 3). Förändringar i kullstorlek och äggskalskvalitet hos ett antal arter har upptäckts i en strandzon om ca $100 \mathrm{~m}$ bredd längs sjön StorTjulträsket, av allt att döma en effekt av sur nederbörd. Bedömningen är dock att denna störning inte påverkat småfågelsamhället märkbart inom det vidsträckta fältarbetsområdet i övrigt.

\section{Metoderna}

\section{Fågelinventeringarna}

Fågelförekomsten har räknats av på två sätt:

1) Kartering av främst sjungande hanar under tio besök i provytor av känd storlek, av vilka de flesta inventerats alla säsonger. Karteringsresultaten har tolkats enligt de internationellt gällande reglerna och resultaten motsvarar därmed ungefär antal revir i provytorna. Dessas antal och storlek presenteras i Tabell 1. De inventerare som karterat under åren är listade i Tabell 2.

2) Protokollgång, ett slags linjetaxering som innebär, att man genomkorsar fältarbetsområdet ett antal gånger under det att man antecknar alla hörda sjungande hanar och övriga observationer som antyder förekomsten av en häckning eller ett revir. Protokollgångarna tjänar som ett nödvändigt komplement till provytekarteringarna. Många arter är nämligen så glest förekommande i fjällbjörkskogen att de riskerar att antingen inte alls bli registrerade i provytorna eller endast $i$ så litet antal att informationen om deras förekomst blir för osäker. Alla inventeringar har utförts under juni månad. Protokollgångarna med deltagare redovisas i Tabell 3.

De siffror på fågeltätheten som används (Appendix 3) utgörs av s.k. härledda täthetsvärden (ungefär motsvarande antal revir $/ \mathrm{km}^{2}$ ). I princip, men starkt förenklat uttryckt, beräknas dessa för varje art genom att man multiplicerar dess andel av totalantalet observationer i protokollgångmaterialet med fågelsamhällets täthet, såsom denna fastställts i provytorna. Den härledda tätheten är ett index, vars främsta värde ligger i att det för alla arter liksom för totalbeståndet kan användas för registrering av ändringarna i tätheten från säsong till säsong.

\section{Insektsinventeringarna}

Dessa igångsattes 1967, främst med sikte på att bestämma antalet fjällbjörkmätarlarver på björkarna enligt ett standardiserat förfarande. Dessa räkningar genomfördes i särskilda provytor och startade då björklöven just börjat slå ut, oftast under tredje juniveckan. Fältarbetet pågick i ca. två veckor och fördelades under perioden på fyra personer (Tabell 4). I varje provyta undersöktes 1000 kortskott (bladrosetter) sex gånger per säsong och alla funna insekter, spindlar och kvalster bokfördes. Förekomsten redovisas i antal djur per 1000 kortskott. I denna uppsats redovisas endast björkmätarmaterialet.

\section{Temperaturen}

Temperaturen utomhus har avlästs i Ammarnäs. Då temperaturuppgift saknats för någon säsong har den räknats fram för Ammarnäs med hjälp av mätningarna vid andra väderstationer i regionen.

\section{Inventeringsmaterialets kvalitet}

En lång inventeringsserie är av värde endast om den genomgående bygger på en väl utprovad teknik som alltid följs till punkt och pricka och om man känner till och kan eliminera följderna av de personbyten som i det långa loppet aldrig kan undvikas. I tidigare studier har inventeringsmetodernas egenskaper undersökts vad gäller precisionen i registreringsarbetet och känsligheten för skillnader mellan olika personers egenskaper som inventerare. Från detta drar vi slutsatsen att insamlade data är av den kvalitet som krävs för att analysarbetet skall bli meningsfullt.

Endast fyra personer har deltagit i insektsinventeringarna. Särskilda test har visat att personbyten inte medför några skillnader i precisionen. Inte heller har 
olika omgivningsfaktorer såsom temperatur, regn eller vindstyrka spelat in. Vad gäller björkmätarlarverna med sina dramatiska fluktuationer torde inventeringsresultaten vara helt tillförlitliga.

\section{Inventeringsresultaten}

Alla arter som observerats under inventeringsarbetet under de 37 åren redovisas i Appendix 1. I Appendix 2 presenteras de täthetsvärden som erhållits i provytorna för alla tättingar utom kråkfåglarna. Dessa har uteslutits eftersom de inte kan karteras tillförlitligt. De är dessutom mycket glest förekommande och har konstaterats häcka inom provytorna under endast två av de 37 åren. De härledda tätheterna för samma kategori arter återfinns i Appendix 3, och i Appendix 4, slutligen, visas medeltemperaturen för månaderna maj, juni och juli.

Täthetsvariationen över åren har illustrerats i diagramform för hela småfågelsamhället i Figur 4 och för de 20 arter, som varit närvarande i området minst 32 av de 37 säsongerna, i Figur 5. Redovisningen av insektsinventeringarna är begränsad till fjällbjörkmätarlarverna. De dramatiska fluktuationerna visas i Figur 6. En sammanfattande karakteristik av temperaturväxlingarna genom åren ges i Tabell 5.

\section{Analys och diskussion}

\section{Småfågelsamhällets artsammansättning och artantal}

Medeltätheten för de 20 vanligast förekommande arterna visas i diagramform i Figur 7. Jämfört med motsvarande diagram i 20-årsuppsatsen har fyra arter tillkommit, nämligen ängspiplärka, gulärla, grönsiska och domherre. Från att tidigare ha varit sporadiska, har de uppträtt årligen under de senaste 17 säsongerna. Som alltid är lövsångaren och bergfinken de överlägset dominanta med lövsångaren som den oinskränkte härskaren. Ingen art har någonsin varit i närheten av lövsångarnivån i talrikhet.

Antalet registrerade arter har fluktuerat mellan 21 och 34 under de 37 säsongerna (Figur 8). Antalet uppvisar en stigande trend genom åren, i snitt innebärande ett tillskott av en art vart fjärde år. Anledningen till ökningen är främst att tidigare sporadiskt uppträdande arter blivit årsvissa. Andra arter som uppträtt först under senare år är fortfarande tillfälliga. En av dessa ser ut att vara på gång att bli årsviss, nämligen grönfinken. Endast tre arter, som registrerades sporadiskt under tidigare år, har uteblivit helt under de senaste decennierna, nämligen trädkryparen, varfågeln och ortolansparven.

\section{Artomsättningen}

Endast 16 arter har varit närvarande i studieområdet alla 37 säsongerna, vilket betyder ca $60 \%$ av det årliga medelantalet arter. Med andra ord, artomsättningen mellan säsongerna har varit betydande (Figur 8). Artomsättningen har i genomsnitt hållit sig på samma nivå genom 37-årsperioden. Totalantalet registrerade arter är 46. Eftersom 16 av dessa varit årsvissa, har övriga 30 deltagit $\mathrm{i}$ ut- och inflyttningen, en trafik som alltså varit betydande.

Ett specialfall av analysen av artomsättningen visas i Figur 9. Om man förlänger tidsavståndet mellan de jämförda säsongerna, kan man förvänta sig, att skillnaden ökar mellan de båda säsongernas artuppsättning, dvs omsättningen blir större. Diagrammet visar att så är fallet. Artomsättningen stiger från ca $25 \%$ upp till 40\%-nivån.

\section{Det totala småfågelsamhällets täthetsvariation}

Det är känt, att de enskilda fågelarternas populationer i Europa varierar mer i täthet mellan åren ju längre norrut man kommer. En blick på artdiagrammen i Figur 5 ger klart besked om att fluktuationerna är betydande i fjällbjörkskogen. Karakteristiken gäller även de totala fågelsamhällena,näven om utslagen då är mindre dramatiska, vilket beror på att de enskilda arternas fluktuationer delvis tar ut varandra. Dock är variationen i täthet hos fjällbjörkskogens fågelsamhälle avsevärd, vilket framgår av Figur 4. Minimitätheten är endast drygt $40 \%$ av maximitätheten, med motsvarande täthetsindex på 236 resp. 564 revir $/ \mathrm{km}^{2}$. Medeltätheten för 37-årsperioden är $403 \pm 85$ revir $/ \mathrm{km}^{2}$.

Det totala antalet fåglar i fågelsamhället ändrade sig inte över studieperioden. Detta utesluter dock inte att dramatiska kortsiktiga minskningar och ökningar $i$ antal inträffat. Att sådana ägde rum runt det andra decenniet i 37-årsserien, kan man ana av diagrammet i Figur 4, men åskådliggörs tydligare av kurvan i Figur 10. Den visar medelvärdena för fågelbeståndets täthet under 10-årsperioder, det första för säsongerna 1963-1972, det andra 1964-1973 osv. till det sista för säsongerna 1990-1999, alltså totalt 28 perioder. Den varaktiga djupdykning, som fågeltätheten uppvisar i diagrammet, måste ha orsakats av viktiga omgivningsfaktorer i häckningsmiljön, eftersom praktiskt taget alla arter deltog i nedgången. Mera därom i det följande. 


\section{Temperaturens påverkan på fågelsamhällets numerär}

Det skall från början understrykas att då betydelsen av temperaturen behandlas, så menas därmed inte att denna som sådan direkt påverkar t.ex. fåglarnas antal, utan att detta sker genom kända eller okända omgivningsfaktorer som samvarierar med temperaturen. Eftersom inventeringarna i vårt studieområde pågått under så lång tid gjordes ett försök att undersöka om något samband kunde påvisas mellan temperaturen och fågeltillgången genomnåren. Medeltemperaturerna för månaderna maj, juni och juli behandlades var för sig av bl.a. följande skäl: 1 . Varmluftinbrott i maj påverkar snöns avsmältning samt kan stimulera vissa kontingenter vårflyttande fåglar att förlänga sin flyttning norrut, vilket skulle leda till högre tätheter varma vårar. 2. Juni-temperaturen är på flera sätt av betydelse för häckningsframgången. 3. Juli-temperaturen påverkar de flygga ungarnas utveckling till självständiga individer och de gamla fåglarnas möjlighet till återhämtning efter häckningsansträngningen.

Medeltemperaturen för hela 37-årsperioden presenteras för var och en av de tre månaderna i Tabell 5. Som väntat skiljer sig månadstemperaturerna signifikant från varandra. Skillnaden mellan högsta och lägsta månadsmedelvärde var sju grader för maj, sex för juni och fem för juli. Månadernas medeltemperatur samvarierar icke, dvs en varm juni kan mycket väl följas av en kall juli.

Sambandet mellan medeltemperaturerna och fågeltätheten har undersökts statistiskt med korrelationstest (Tabell 6). Fågeltätheten en viss säsong jämfördes inte bara med månadernas medeltemperatur samma säsong utan även med temperaturerna ett och två år tidigare. För maj månad finns inget samband, vilket år man än väljer att jämföra med. Junitemperaturen samvarierar med fågeltätheten med två års fördröjning. Det betyder att ett gynnsamt varmt juniväder åtföljs av höjd fågeltäthet nästnästa säsong. Även juli-temperaturen samvarierar med fågeltätheten och detta med ett års fördröjning. Om man korrelerar fågeltätheten för varje år med den sammanslagna temperaturen för juni och juli två resp. ett år tidigare, blir samvariationen än tydligare, vilket framgår av sista raden i Tabell 6.

Vi tolkar resultaten som följer. Det är okontroversiellt att en högre medeltemperatur i juni främjar en effektivare häckning (tidigare och större äggkullar, ökat antal flygga ungar per häckning, m.m.). Det knepiga är att detta kan avläsas i en höjning av fågeltätheten först två år senare. En förklaring kan vara att de återvändande ett-åriga ungfåglarna i stor utsträckning inte lyckas etablera varaktiga revir utan kommer till häckning först som två-åringar. Det har länge misstänkts att bland tättingarna en varierande andel av de överlevande ett-åriga hanarna, även om de återkommer till häckningsområdet, inte lyckas fullt ut med den komplicerade processen att etablera revir och attrahera en hona. Kunskapen om ettåringarnas öden under häckningstiden är emellertid ännu fragmentarisk. Men våra resultat antyder att andelen icke häckande ett-åringar är relativt stor i de nordliga, klimatiskt kärvare regionerna. Detta stöds av erfarenheterna av de holkhäckande svartvita flugsnapparna i Ammarnäs liksom av blåhakebeståndet i nordligaste Finland, där häckande ett-åriga hanar är en sällsynthet. Vad juli-temperaturen beträffar, är det rimligt att tänka sig, att den är av betydelse för inte minst ett-åringars och färdighäckade föräldrafåglars möjlighet att i tid komma i god kondition inför den förestående flyttningen. Ett gynnsamt juliväder en säsong skulle innebära, att en större andel överlever till nästa år och då orsaka den konstaterade ökningen i fågeltätheten.

Temperaturens betydelse kan åskådliggöras även på sätt, som visas i Figur 10. Kurvorna där bygger på s.k. glidande medelvärden för 10-års perioder, en metod som förklarades ovan. Med detta förfarande minskas effekten av sådana tillfälliga och dramatiska svängningar, som endast "rör till bilden". Diagrammet visar tydligt hur kurvorna för temperaturen i juni och för fågelbeståndets täthet följer varandra under den första och större delen av inventeringsperioden. Detta understryker betydelsen av junitemperaturen för hur variationen i småfågeltätheten utvecklas.

Vad gäller relationen mellan maj-temperaturen och fågeltätheten ger Tabell 6 inga statistiskt hållbara besked och här skall inte spekuleras över möjliga tolkningar.

\section{Artbeståndens fluktuationer}

I Figur 5 är de 20 vanligaste arternas fluktuationer presenterade som kurvor. Svängningarna mellan åren kan vara betydande. Samma arters variationsmönster är karakteriserade även i Tabell 7, där bl.a. även medeltätheter för perioden och trender i beståndsutvecklingen är angivna. De senare kan avläsas i b-spalten, där minus-tecken betyder, att trenden är vikande. För 11 arter är trenderna inte statistiskt signifikanta (n.s.). Säkra trender uppvisar däremot de återstående nio, vilka alla är sparsamt förekommande. Till de ökande arterna hör de som blivit årsvissa under senaste decennier, nämligen ängspip- 
lärka, gulärla, grönsiska och domherre, vartill kan läggas även "gamlingen" grå flugsnappare. Till förlorarna hör taltrast, trädgårdssångare, svartvit flugsnappare och talltita, vilka alltid varit företrädda med relativt glesa bestånd. Som väntat följer de flesta arterna den ovannämnda djupdykning som totalbeståndets täthet visar med de glidande medelvärdena för 10-årsperioderna med minimum för perioden 1975-1984 (Figur 10). Detta gäller för lövsångare, bergfink, rödvingetrast, trädpiplärka, rödstjärt, björktrast, grå flugsnappare, svartvit flugsnappare, talltita, bofink och grönsiska. Samma förlopp uppvisas även av järnsparv, blåhake, taltrast, trädgårdssångare och sävsparv, dock med minimiperioden senarelagd med ett till tre år. De återstående arterna ängspiplärka, gulärla och domherre avviker helt från detta mönster.

\section{Artbeståndens storlek och temperaturen}

Det starka sambandet mellan den kombinerade junioch juli-temperaturens och det totala fågelsamhällets fluktuationer, som ovan visats, gäller för endast ett fåtal av de enskilda artpopulationerna (Tabell 8). Visserligen är sambandet positivt i de allra flesta fall, men ett statistiskt övertygande sådant uppvisar endast bergfink och gråsiska, för enstaka delperioder även rödvingetrast, björktrast och rödstjärt.

Man skulle annars tro, att temperaturtillståndet skulle påverka tropikflyttarna mest. Förvånande är att lövsångaren, i varje fall av koefficienterna att döma, är så okänslig. Den har hög täthet och inventeras med stor säkerhet, varför informationen i tabellen måste sägas vara trovärdig. Arten är uppenbarligen väl anpassad att framgångsrikt bemästra det instabila och ofta bistra temperaturläget i fjällbjörkskogen.

Även om fördelningen av temperaturens sätt att påverka arterna ter sig något oväntad, reagerar arterna enstämmigt på den långsiktiga genomsnittliga temperaturutvecklingen, såsom ovan visats med hänvisning till de 10-åriga glidande medelvärdena. Artbeståndens glidande medelvärden följer alla $\mathrm{i}$ stort sett totalbeståndets kurva (Figur 10), vilket alltså gäller även för lövsångaren.

\section{Fjällbjörkmätarlarvernas betydelse}

Variationen i fjällbjörkmätarlarvernas förekomst under åren visas i Figur 6. Under de aktuella 33 åren har tre massförekomster inträffat och varat i fyra eller fem säsonger. Larverna utgör ett avsevärt näringstillskott för småfågelbeståndet, eftersom det allmänt har observerats, att många arter matar sina ungar med gröna larver.

Den tredje larvtoppen nådde långt ifrån samma höjd som de båda föregående, men den torde ha haft samma betydelse för häckningarna eftersom alla massförekomster från näringssynpunkt resulterar i ett ofantligt outnyttjat överskott. Förmodligen är larvförekomsten optimal ur fåglarnas perspektiv redan vid mycket låga nivåer. Dessutom skall man icke glömma, att de enorma “överskotten" på betande larver frestar hårt på främst björkarna men även på övrig vegetation. Vissa björkar kan kalätas helt. Ibland kan detta drabba hela björkskogsområden, vilket skedde under den andra toppen, dock utanför inventeringsområdet. Även om larverna utgör ett näringstillskott för småfåglarna, kan det inte uteslutas, att den ofta brutala nedbetningen av vegetationen kan ha negativa följder för andra näringskällor av betydelse för många arters häckningsframgång.

Under de larvrika säsongerna ökar antalet fågelarter i studieområdet. Kurvan över artantalet visar tre toppar med 31, 33 och 34 arter, vilka alla inträffade under larvperioderna (Figur 8). Däremot tycks fågelsamhällets täthet inte följa variationerna i larvförekomsten (Tabell 9). Inte heller ökar tätheten med ett eller två års försening, såsom fallet var med temperatursambandet. Detta skulle ha inträffat om larvåren betytt framgångsrikare häckning. Istället tenderar ökningen av fågeltätheten att ligga ett år före larvuppgången, något som kan skyllas på en av de talrikaste arterna i björkskogen, nämligen bergfinken (se nedan).

Sambandet mellan larvförekomsten och populationstätheterna har undersökts för de 14 vanligaste arterna och resultatet för fem av dem visas i Tabell 9. För alla arter gäller att bilden är rörig. Positiva och negativa statistiskt osäkra samband blandas med varandra. De i tabellen upptagna arterna ger dock vissa besked. Klarast bland dem är bergfinken, som inte bara följer ändringarna i larvförekomsten samma år utan även, och än tydligare, ett år i förväg. I gengäld går dess täthet senare ned i förväg jämfört med larvkurvan (Figur 6). Detta är kanske en följd av en nedgång i larvernas kvalitet som näringskälla under senare delen av massförekomstperioden.

Även om de nomadiska bergfinkarna ansamlas och häckar i stora tal under larvåren, visar Figur 6 att artens kurva kan uppvisa toppar även mellan massutbrotten. Tabell 9 ger klart besked om att någon ökning i bergfinktätheten med ett eller två års fördröjning ej inträffar. Någon återkomst av larvårens säkerligen ökade produktion av ungfåglar tycks alltså inte ske, vilket väl kanske ej är att vänta hos denna 
rörliga art. Så är dock fallet hos tre markhäckande arter, sävsparven, trädpiplärkan och blåhaken, vilka alla visar en ökning i beståndstätheterna med två års fördröjning, hos trädpiplärkan även efter ett år och hos blåhaken fortfarande efter tre år. Detta torde ha sin grund i de många återvändande ett- eller tvååringar som är resultatet av ökad häckningsframgång under larvåren.

Den insektätande lövsångaren varierar i antal helt oberoende av massförekomsten av larver. Arten tycks vara lika "okänslig" för larvmassorna som för korttidsvariationerna i temperaturen. Gråsiskan utgör ett särfall, eftersom den överlag uppvisar negativa, låt vara ej statistiskt säkra koefficienter (Tabell 9). Arten tenderar alltså att variera i antal motsatt mot larvtätheten. Detta kan möjligen vara en följd av larvernas kraftiga nedbetning av den fröproducerande växtligheten. Gråsiskan är ju en specialiserad frökonsument som även matar sina boungar till icke ringa del med frön av olika slag.

\section{Jämförelse mellan de olika arternas variation $i$ antal}

Om två arter i ett småfågelsamhälle konkurrerar med varandra om utrymme, boplats eller föda, kan följden bli, att deras antal fluktuerar på ett sinsemellan motsatt sätt mellan säsongerna. Finns ingen konkurrens beroende t.ex. på överflöd på resurser i biotopen, är det alltså fritt fram för samstämmiga, parallella fluktuationer. Genom att jämföra arterna par för par vad gäller samstämmigheten i deras fluktuationsmönster kan man alltså få en fingervisning om resursläget $i$ fågelsamhället. Detta har gjorts för de 20 arter som påvisats i inventeringsområdet under minst 32 av de 37 säsongerna. Av de 190 möjliga parjämförelserna har 151 uppvisat positiva korrelationskoefficienter och alltså samvarierat. Inte mindre än 50 av dessa var statistiskt säkra. Endast 39 par visade motsatta fluktuationsmönster, varav endast fyra var rimligt säkra. Efter ytterligare statistiska överväganden kunde slutsatsen dras att fågelsamhället domineras av samstämmiga fluktuationer mellan arterna, samt att motsatta fluktuationer är en sällsynthet. I fågelsamhället tycks alltså ett relativt obetydligt konkurrenstillstånd råda mellan arterna, vilket kan tolkas som en följd av att miljön är långt ifrån så tätt befolkad med fågel som dess resursinnehåll skulle kunna tillåta. Med andra ord, fjällbjörkskogen skulle vara en s.k. omättad biotop vad gäller småfågelantalen.

Vad som sagts utesluter inte att artparen uppvisar olika grader av inbördes samvariation. I 20-årsupp- satsen grupperades arterna på basis av just graden av likhet i fluktuationsmönstren. Det visade sig då att långflyttarna (till tropikerna) bildade en grupp för sig (A i Figur 11) och kortflyttarna (till bl.a. nordsjöländerna) två andra sinsemellan skilda grupper (B och $\mathrm{C}$ ). Slutsatsen blev då att överlevnaden under flyttning och övervintring inverkar starkt på hur fågelantalet varierar i häckningsområdet så att de arter som har samma flyttnings- och övervintringsekologi kan förväntas variera likartat i antal mellan säsongerna. Hur arterna grupperas på basis av graden av samvariation, har illustrerats med s.k. rutdiagram för såväl perioden 1965-1982 som hela 37årsperioden (Figur 11). Förlängningen av inventeringsperioden från 18 till 37 år medförde inte några genomgripande förändringar i artgrupperingarna. För kommentarer i övrigt hänvisas till bildtexten.

\section{Kortflyttarna kontra långflyttarna}

Jämförande studier av småfågelsamhällenas sammansättning från söder till norr i Europa har visat att andelen tropikflyttande arter ökar norrut, medan alltså de stannande och kortflyttande arterna minskar. Detta har tolkats som en följd av konkurrens mellan de båda artgrupperna. Kortflyttarna är inför häckningen först på plan och tar den resurs de behöver, medan de senare anländande tropikflyttarna lägger beslag på återstoden, så långt denna räcker. De fåglar som blir utan får söka sig norrut. Man inser också lätt att om stannarna och kortflyttarna minskar i antal som följd av t.ex. inträffade bistra förhållanden i deras nordligt belägna övervintringsmiljöer finner tropikflyttarna mer ledig plats och kan öka i antal i häckningsområdet. De båda artgrupperna skulle därmed tendera att uppvisa motsatta fluktuationer i täthet mellan säsongerna, vilket dokumenteras med negativ korrelationsfaktor vid statistisk prövning. Så var fallet i den lilla fågeltäta provytan Fågelsångsdalen i Skåne där de båda artgrupperna varierat på ett motsatt sätt över en period om 40 år.

För fjällbjörkskogarna i Ammarnäs gäller att andelen tropikflyttande arter i genomsnitt utgör 40\% av småfågelsamhällets artinnehåll, samt att tropikflyttarna svarar för hälften av samhällets täthet. De båda artgruppernas fluktuationsmönster visar sig dock vara i hög grad samstämmiga (Figur 12), vilket antyder att inget mera påtagligt konkurrenstillstånd finns mellan fjällens kort- och långdistansflyttare. Detta är också i linje med tidigare slutsatser om fjällbjörkskogens omättade tillstånd vad gäller antalet småfåglar. 


\section{Exempel på långtidsinventeringarnas förtjänster och brister}

Ingen förnekar att långtidsinventeringar är ett måste om man vill gripa trender och styrmekanismer i fågelsamhällenas eller de enskilda arternas antalsutveckling. Men man kan ställa sig frågan om det egentligen från informationssynpunkt varit vettigt att hålla på så länge som 37 år, m.a.o. om något av verkligt intresse avslöjats som följd av just det envisa långtida inventerandet. Förhoppningen att så skulle bli fallet var den främsta av de drivkrafter som hållit det ensartade oförändrade fältarbetet vid liv så länge (och gör så alltfort). Här följer några valda exempel som visar att denna förväntan inte kommit helt på skam.

Fågelsamhällets täthet har över de 37 åren i genomsnitt legat på oförändrad nivå. Det utesluter inte att häftiga svängningar förekommit. Ett exempel är den mångåriga djupa svacka som visas i Figur 10. Hade inventeringarna avbrutits efter 22 år, alltså redan då ett respektabelt långtidsprojekt, då hade det legat nära till hands att misstänka och kanske "larma ut" att en för fågelsamhället negativ faktor är i farten. Tack vare det fortsatta arbetet kunde det visas att fågelbeståndet så småningom klättrade upp till normal nivå igen. Katastrofhotet kunde avskrivas.

Som tidigare visats föreligger ett klart samband mellan temperaturen under häckningen i juni och fågelsamhällets täthet två år senare, något som länge under analysarbetet verkade framstå som en orubblig sanning. Men sambandet visade sig vackla under det senaste decenniet av 37-årsperioden vilket antyder att andra faktorer kan överskugga temperatureffekten. Detta är en viktig, ännu ej analyserad information, som erhållits endast tack vare det fortsatta envisa fågelräknandet.

Vi var från början säkra på att endast en mycket lång rad av inventerade säsonger kunde ge tillförlitlig information om fågelsamhällets reaktion på fjällbjörkmätarlarvernas massuppträdanden, detta av den enkla anledningen att larvtopparna inträffar endast en gång per decennium. Med tre toppar över 37 år till förfogande blev beskedet att fågeltätheten med undantag för bergfinken förblev i stort sett opåverkad av det näringstillskott som larvmassorna utgjorde. Detta födde i sin tur misstanken att fjällbjörkskogen normalt utgör en så rik näringsbas för de häckande småfåglarna att det stora larvtillskottet för flertalet arter framstår som mindre "intressant", en betydelsefull fingervisning i försöken att tolka fågelsamhällets dynamik.

Flera forskare har diskuterat problemet, hur många år en inventering skall pågå för att kunna betecknas som en från informationssynpunkt tillräckligt långtida ("long-term") sådan. Frågan har naturligtvis inget klart svar, men det har antytts, att tio år är en rimlig undre gräns. Med diagrammen i Figur 13 visas hur en tioårsperiod kan ge en fullständigt felaktig information om vad som normalt gäller. Exemplet är den mycket täta samvariation i antal som björktrast och rödvingetrast uppvisat under inventeringsårens förlopp (det övre diagrammet). Om samvariationen däremot testas för varje enskild 10-årsperiod får man det resultat som visas i det nedre diagrammet. Man ser att det inte föreligger något som helst samband mellan de båda trastarnas beståndsväxlingar under perioden 1975-1984. Om inventeringarna begränsats till just detta decennium, hade man trots projektets långtidskaraktär förblivit helt ovetande om vad som är normalt över längre perioder.

Av allt detta kan man lära, att det inte finns någon övre gräns för en inventeringssvits utsträckning $i$ tid, däremot åtskilliga undre gränser, vilket i vår föränderliga värld egentligen är en självklarhet.

\section{Varför är fjällbjörkskogen inte "till brädden" fylld med småfågel?}

Resultaten av några analyser ovan gav anledning till förmodan att fågelsamhället i fjällbjörkskogen är omättat, dvs fler fåglar än vad inventeringarna utvisar skulle kunna häcka där. I 20-årsuppsatsen redovisas fler resultat som kan förstås bäst om biotopen förutsätts vara omättad, vilket bl.a. skulle betyda att fåglarna där upplever en förhållandevis konkurrensfri situation. Även om direkt bevis ännu saknas, verkar det som om detta "underskott” är något som är särskilt utmärkande för fjällbjörkskogens fågelbestånd och som uppenbarligen inte gälller för lövskogsmiljöer längre söderut, såsom i Polen. Hur skall denna "fågelbrist" i norr förklaras? Ett otvetydigt svar är ännu inte inom räckhåll, varför man är hänvisad till gissningar.

Man kan tänka sig att fåglarna brister i häckningseffektivitet i fjällbjörkskogen. Mot detta talar att äggkullarna är stora och att äggen hos nio undersökta tättingarter är lika stora eller större än dem längre söderut. Häckningen är också tillräckligt effektiv för att vid gynnsam temperatur i juni kunna resultera i en beståndsökning såsom visats ovan. Att de flesta arter inte reagerar på det näringstillskott som utbrotten av mätarlarver innebär tyder på att annan föda finns i rikt mått. Man kunde tycka att beståndet därmed skulle så småningom kunna fylla biotopen till brädden, men så sker uppenbarligen inte. 
En fingervisning kan kanske ligga i det faktum att fågelsamhället i fjällbjörkskogen är påfallande instabilt, dvs varierar kraftigt i täthet mellan säsongerna. Jämfört med fågeltätheten i välundersökta lövskogar i Polen är skillnaden mellan högsta och lägsta beståndstäthet tre gånger större och största förändringen i täthet från den ena säsongen till nästa fyra gånger större i norr. Det har sedan länge ansetts att den främsta orsaken härtill är de ofta häftiga omkastningarna i väderleksläget i norr, samt att de extrema vädertillstånden har katastrofalare följder för häckningsresultaten i norr jämfört med dem i söder. Till detta kan läggas att den korta häckningssäsongen i norr betyder att möjligheten att med omhäckning minska skadeverkningarna där är betydligt mindre. Kanske är det alltså så att ofta förekommande utbrott av dåligt väder (kyla, regn, snö) hindrar fågelbeståndet att "föröka upp sig" till i nivå med vad biotopen kan bära. Man kan spekulera i om den förmodade globala uppvärmningen (växthuseffekten) med tiden kommer att förändra fjällbjörkskogens fågelsamhälle i riktning mot lugnare variationmönster och högre täthet. 


\section{Appendices}

Appendix 1. Bird species annotated during the census work in the subalpine birch forest of the study area at Ammarnäs in 1963-1999, with number of seasons present. Asterisks (*) indicate confirmed or potential breeders in the habitat.

Fågelarter påträffade under inventeringsarbetet ifjällbjörkskogen i Ammarnäs under åren 1963-1999, med antalet säsonger då arten setts. Arter som är konstaterade eller tänkbara häckare i skogen är markerade med asterisk (*).

\begin{tabular}{|c|c|c|c|}
\hline Gavia stellata & 8 & Phoenicurus phoenicurus* & 37 \\
\hline Anas penelope & 2 & Saxicola rubetra* & 25 \\
\hline Anas crecca & 3 & Oenanthe oenanthe* & 6 \\
\hline Aythya marila & 4 & Turdus torquatus* & 26 \\
\hline Melanitta nigra & 2 & Turdus merula* & 22 \\
\hline Bucephala clangula & 2 & Turdus pilaris* & 37 \\
\hline Haliaeetus albicilla & 1 & Turdus philomelos* & 37 \\
\hline Circus cyaneus* & 4 & Turdus iliacus* & 37 \\
\hline Accipiter gentilis & 1 & Acrocephalus schoenobaenus & 9 \\
\hline Accipiter nisus* & 7 & Acrocephalus dumetorum & 1 \\
\hline Buteo lagopus* & 30 & Hippolais icterina* & 22 \\
\hline Aquila chrysaetos & 3 & Sylvia curruca* & 6 \\
\hline Falco tinnunculus* & 8 & Sylvia borin* & 36 \\
\hline Falco columbarius* & 33 & Sylvia atricapilla* & 13 \\
\hline Bonasia bonasia & 1 & Phylloscopus trochiloides & 1 \\
\hline Lagopus lagopus* & 37 & Phylloscopus borealis* & 3 \\
\hline Tetrao tetrix* & 30 & Phylloscopus sibilatrix* & 14 \\
\hline Tetrao urogallus* & 36 & Phylloscopus collybita* & 3 \\
\hline Pluvialis apricaria & 7 & Phylloscopus trochilus* & 37 \\
\hline Gallinago gallinago* & 29 & Regulus regulus & 4 \\
\hline Scolopax rusticola* & 26 & Muscicapa striata* & 37 \\
\hline Tringa totanus & 7 & Ficedula hypoleuca* & 37 \\
\hline Tringa nebularia & 10 & Parus montanus* & 37 \\
\hline Tringa glareola & 12 & Parus cinctus* & 8 \\
\hline Actitis hypoleucos & 20 & Parus major* & 37 \\
\hline Phalaropus lobatus & 1 & Certhia familiaris* & 3 \\
\hline Larus canus & 5 & Lanius excubitor* & 2 \\
\hline Columba palumbus & 3 & Perisorius infaustus & 2 \\
\hline Cuculus canorus* & 36 & Pica pica & 2 \\
\hline Surnia ulula* & 18 & Corvus corone* & 37 \\
\hline Asio flammeus* & 6 & Corvus corax* & 29 \\
\hline Jynx torquilla* & 21 & Sturnus vulgaris & 2 \\
\hline Dendrocopos minor* & 16 & Fringilla coelebs* & 37 \\
\hline Picoides tridactylus* & 30 & Fringilla montifringilla* & 37 \\
\hline Riparia riparia* & 13 & Carduelis chloris* & 4 \\
\hline Hirundo rustica & 2 & Carduelis spinus* & 34 \\
\hline Delichon urbica & 11 & Carduelis flammea* & 37 \\
\hline Anthus trivialis* & 37 & Carduelis hornemanni* & 8 \\
\hline Anthus pratensis* & 33 & Loxia leucoptera & 2 \\
\hline Motacilla flava* & 32 & Loxia curvirostra/pytyopsittacus & 19 \\
\hline Motacilla alba* & 23 & Carpodacus erythrinus* & 2 \\
\hline Bombycilla garrulus & 1 & Pinicola enucleator & 1 \\
\hline Cinclus cinclus $*$ & 22 & Pyrrhula pyrrhula* & 32 \\
\hline Troglodytes troglodytes* & 12 & Emberiza cintrinella* & 10 \\
\hline Prunella modularis* & 37 & Emberiza hortulana & 2 \\
\hline Erithacus rubecula* & 13 & Emberiza pusilla* & 3 \\
\hline Luscinia svecica* & 37 & Emberiza schoeniclus* & 37 \\
\hline
\end{tabular}


Appendix 2.Densities of the passerine species (excl. Corvidae) (territories $/ \mathrm{km}^{2}$ ) as obtained by mapping or nest search in the study plots in the rich subalpine birch forests on the south-facing slopes of the mountains Gaisatj and Valle near Ammarnäs, Swedish Lapland, 1963-1999. Census-takers and study plots are presented in Tables 1 and 2.

Småfågelarternas täthet (revir $/ \mathrm{km}^{2}$ ), bestämd genom revirkartering eller boletning i provytorna i den rika fjällbjörkskogen på sydsluttningen av lågfjällen Gaisatj och Valle i Ammarnäs-området $i$ södra Lappland. Inventerarna och provytorna presenteras i Tabell 1 och 2.

\begin{tabular}{|c|c|c|c|c|c|c|c|c|c|c|c|c|c|c|c|c|c|c|c|}
\hline Species & 1963 & 64 & 65 & 66 & 67 & 68 & 69 & 70 & 71 & 72 & 73 & 74 & 75 & 76 & 77 & 78 & 79 & 80 & \\
\hline & 1981 & 82 & 83 & 84 & 85 & 86 & 87 & 88 & 89 & 90 & 91 & 92 & 93 & 94 & 95 & 96 & 97 & 98 & 99 \\
\hline \multirow[t]{2}{*}{ Anthus trivialis } & 8.3 & 15.8 & 6.8 & 5.7 & 9.6 & 3.8 & 3.8 & 3.8 & 5.7 & 4.8 & 2.4 & 4.8 & 14.3 & 11.9 & 14.3 & 9.5 & 4.8 & 2.4 & \\
\hline & 4.8 & 7.1 & 4.8 & 7.2 & 11.9 & 2.4 & 11.9 & 11.9 & 14.3 & 11.9 & 9.5 & 4.8 & 11.9 & 4.8 & 9.5 & 9.5 & 9.5 & 9.5 & 11.9 \\
\hline \multirow[t]{2}{*}{ Anthus pratensis } & - & 6.8 & - & - & - & - & - & - & - & - & - & - & - & - & - & - & - & - & \\
\hline & - & - & - & - & - & - & - & 2.4 & 2.4 & 2.4 & 2.4 & - & - & - & - & 2.4 & - & - & - \\
\hline \multirow[t]{2}{*}{ Motacilla flava } & - & - & - & - & - & - & - & - & - & - & 2.4 & - & - & - & - & - & - & - & \\
\hline & 2.4 & 2.4 & 2.4 & 2.4 & - & 2.4 & 2.4 & 2.4 & 2.4 & 2.4 & - & - & - & 2.4 & 2.4 & 2.4 & & 2.4 & - \\
\hline \multirow[t]{2}{*}{ Motacilla alba } & - & - & - & - & - & - & - & - & - & - & - & - & - & - & - & - & - & - & \\
\hline & - & - & - & - & - & - & - & - & & - & - & 2.4 & - & - & - & - & - & - & 2.4 \\
\hline \multirow[t]{2}{*}{ Cinclus cinclus } & - & - & - & - & - & - & - & - & 1.9 & - & - & & - & - & - & - & - & - & \\
\hline & - & - & - & - & - & - & - & - & - & - & - & - & - & - & - & - & - & - & - \\
\hline \multirow[t]{2}{*}{ Troglodytes troglodytes } & - & - & - & - & - & - & - & - & - & - & - & - & - & - & - & 2.4 & 2.4 & - & \\
\hline & - & - & - & - & - & - & - & 2.4 & - & - & - & - & 2.4 & - & - & - & - & - & - \\
\hline \multirow[t]{2}{*}{ Prunella modularis } & 22.1 & 33.9 & 22.6 & 21.1 & 36.4 & 21.1 & 40.2 & 19.2 & 26.8 & 16.1 & 35.7 & 35.7 & 31.0 & 33.3 & 31.0 & 35.7 & 21.4 & 14.3 & \\
\hline & 40.5 & 31.0 & 19.1 & 19.1 & 16.7 & 14.3 & 28.6 & 28.6 & 26.3 & 23.8 & 14.3 & 14.3 & 33.3 & 42.9 & 40.5 & 35.7 & 28.6 & 28.6 & 19.0 \\
\hline \multirow[t]{2}{*}{ Erithacus rubecula } & - & - & - & - & - & - & - & - & - & 1.6 & - & 7.1 & - & - & - & - & - & 2.4 & \\
\hline & - & - & - & - & - & - & - & - & - & - & - & - & - & - & - & - & - & 2.4 & - \\
\hline \multirow[t]{2}{*}{ Luscinia svecica } & 2.8 & 6.8 & 13.6 & 13.4 & 38.3 & 21.1 & 7.7 & 3.8 & 15.3 & 14.5 & 47.6 & 21.4 & 11.9 & 23.8 & 14.3 & 23.8 & 4.8 & 2.4 & \\
\hline & 16.7 & 19.0 & 7.2 & 7.2 & 11.9 & 7.2 & 26.3 & 19.1 & 14.3 & 9.5 & - & 4.8 & - & 7.1 & 33.3 & 14.3 & 35.7 & 14.3 & 4.8 \\
\hline \multirow[t]{2}{*}{ Phoenicurus phoenicurus } & 22.1 & 15.8 & 23.9 & 6.9 & 20.8 & 6.9 & 3.5 & 6.9 & 3.5 & 10.3 & 16.2 & 6.5 & 9.7 & 12.9 & 9.7 & 19.4 & 3.2 & 9.7 & \\
\hline & 19.4 & 16.2 & 9.7 & 3.2 & 3.2 & 3.2 & 9.7 & 9.7 & 9.7 & 6.5 & 16.2 & 12.9 & 19.0 & 11.9 & 11.9 & 9.5 & 11.9 & 7.1 & 14.3 \\
\hline Saxicola rubetra & 8.3 & 4.5 & - & 1.9 & - & 1.9 & - & - & - & - & - & - & - & 2.4 & 2.4 & - & - & - & \\
\hline & - & - & - & - & - & - & - & - & - & - & - & - & - & - & - & - & - & - & - \\
\hline Turdus torquatus & - & - & - & - & - & - & - & - & - & - & - & - & - & - & - & - & - & - & \\
\hline & - & - & - & - & - & - & - & - & - & - & 2.4 & - & - & - & - & - & - & - & - \\
\hline Turdus merula & - & - & - & 1.9 & - & - & - & - & - & - & - & 2.4 & - & - & - & - & - & - & \\
\hline & - & - & - & - & - & 2.4 & - & 2.4 & - & - & - & - & - & - & - & - & - & - & 4.8 \\
\hline Turdus pilaris & - & 6.8 & 15.8 & 1.9 & 19.2 & 46.0 & 23.0 & 32.6 & 28.7 & 30.5 & 7.1 & 21.4 & 4.8 & 7.1 & 7.1 & 47.6 & 14.3 & 21.4 & \\
\hline & 19.0 & 14.3 & 14.3 & 11.9 & 23.9 & 9.5 & 71.6 & 47.7 & 81.1 & 28.6 & 71.4 & 16.7 & 28.6 & 14.3 & 33.3 & 38.1 & 88.1 & 57.1 & 14.3 \\
\hline Turdus philomelos & 2.8 & 13.6 & 15.8 & 23.0 & 9.6 & 15.3 & 19.2 & 13.4 & 3.8 & 9.6 & 11.9 & 14.3 & 7.1 & 4.8 & 4.8 & 14.3 & 7.1 & 14.3 & \\
\hline & 14.3 & 9.5 & 2.4 & 2.4 & 2.4 & 2.4 & 11.9 & 4.8 & 31.0 & 16.7 & - & 11.9 & 2.4 & 9.5 & 7.1 & 7.1 & 7.1 & - & 4.8 \\
\hline Turdus iliacus & 16.6 & 6.8 & 47.5 & 17.2 & 24.9 & 55.6 & 44.1 & 59.4 & 24.9 & 49.8 & 59.5 & 40.5 & 11.9 & 7.1 & 14.3 & 19.0 & 7.1 & 28.6 & \\
\hline & 45.2 & 16.7 & 11.9 & 14.3 & 14.3 & 7.2 & 31.0 & 31.0 & 62.1 & 26.2 & 23.8 & 14.3 & 28.6 & 26.2 & 33.3 & 31.0 & 45.2 & 35.7 & 45.2 \\
\hline Hippolais icterina & - & - & - & - & - & - & 1.9 & - & - & - & - & - & - & - & - & - & - & 4.8 & \\
\hline & - & - & - & 2.4 & - & - & - & - & - & - & - & - & 2.4 & - & - & - & - & - & - \\
\hline Sylvia borin & 13.8 & 9.0 & 9.0 & 17.2 & 7.7 & 9.6 & 9.6 & 3.8 & 5.7 & 1.6 & 9.5 & 4.8 & 4.8 & 9.5 & 2.4 & - & 2.4 & 4.8 & \\
\hline & 2.4 & 2.4 & 2.4 & 4.8 & - & 9.5 & 2.4 & 4.8 & 2.4 & 4.8 & - & 2.4 & 2.4 & - & - & 2.4 & 4.8 & 2.4 & - \\
\hline Sylvia atricapilla & - & - & - & - & - & - & - & - & - & - & 2.4 & 2.4 & - & - & - & - & - & - & \\
\hline & - & - & - & 2.4 & - & - & - & - & - & - & & & 2.4 & - & - & - & - & - & - \\
\hline Phylloscopus collybita & - & - & - & - & - & - & - & - & - & - & - & - & - & - & - & - & - & - & \\
\hline & - & - & - & 2.4 & - & - & - & - & - & - & - & - & - & - & - & - & - & - & - \\
\hline Phylloscopus sibilatrix & - & 2.3 & - & - & - & - & - & - & - & - & - & - & - & - & - & - & - & - & \\
\hline & - & - & - & - & 2.4 & & 2.4 & - & - & - & - & - & - & - & - & - & - & - & - \\
\hline Phylloscopus trochilus & 135 & 192 & 199 & 115 & 142 & 151 & 130 & 178 & 148 & 154 & 155 & 131 & 124 & 107 & 117 & 86 & 86 & 74 & \\
\hline & 86 & 126 & 84 & 76 & 184 & 146 & 196 & 243 & 239 & 179 & 121 & 160 & 219 & 214 & 133 & 157 & 164 & 157 & 140 \\
\hline Muscicapa striata & 2.8 & - & 2.3 & 1.9 & - & - & - & - & 3.8 & 3.2 & 9.5 & 4.8 & - & 2.4 & 4.8 & 2.4 & 4.8 & 2.4 & \\
\hline & 11.9 & 2.4 & 4.8 & - & 7.2 & 7.2 & - & 11.9 & 4.8 & 7.1 & 7.1 & 7.1 & 14.3 & 7.1 & 11.9 & 9.5 & 14.3 & 7.1 & 4.8 \\
\hline Ficedula hypoleuca & 16.6 & 20.4 & 28.7 & 13.8 & 20.8 & 10.4 & 17.3 & 10.4 & 34.6 & 15.4 & 12.9 & 22.7 & 22.7 & 12.9 & 3.2 & 9.7 & 6.5 & 3.2 & \\
\hline & 6.5 & 6.5 & - & 12.9 & 9.7 & 12.9 & 16.2 & 12.9 & 19.4 & 16.2 & 12.9 & 6.5 & 7.1 & 7.1 & 2.4 & 4.8 & 9.5 & 4.8 & 4.8 \\
\hline Parus montanus & 11.0 & 4.5 & 9.0 & 1.9 & 1.9 & 3.8 & 3.8 & - & 5.7 & 8.0 & - & 4.8 & 2.4 & - & 2.4 & 4.8 & - & 2.4 & \\
\hline & 2.4 & 2.4 & - & - & 4.8 & - & - & - & 2.4 & - & 4.8 & - & 2.4 & - & 4.8 & 4.8 & 2.4 & 4.8 & - \\
\hline Parus cinctus & - & - & - & - & - & - & - & - & - & - & - & - & - & - & - & - & - & - & \\
\hline & - & - & - & - & 2.4 & 2.4 & - & - & - & - & - & - & - & - & - & - & - & - & - \\
\hline Parus major & - & - & - & - & - & - & - & - & - & - & - & - & - & - & - & 2.4 & - & - & \\
\hline & - & - & - & 2.4 & & 2.4 & - & - & 9.5 & 2.4 & 2.4 & 2.4 & 4.8 & 2.4 & - & - & - & - & 2.4 \\
\hline Certhia familaris & - & - & - & - & - & - & - & - & - & - & - & - & - & - & - & 2.4 & - & - & \\
\hline & - & - & - & - & - & - & - & - & - & - & - & - & - & - & - & - & - & - & - \\
\hline
\end{tabular}


Appendix 2 continued

\begin{tabular}{lccccccccccccccccccc}
\hline Species & 1963 & 64 & 65 & 66 & 67 & 68 & 69 & 70 & 71 & 72 & 73 & 74 & 75 & 76 & 77 & 78 & 79 & 80 & \\
& 1981 & 82 & 83 & 84 & 85 & 86 & 87 & 88 & 89 & 90 & 91 & 92 & 93 & 94 & 95 & 96 & 97 & 98 & 99 \\
\hline Fringilla coelebs & 2.8 & 4.5 & 2.3 & 9.6 & 3.8 & 1.9 & 1.9 & 1.9 & 1.9 & - & 2.4 & 11.9 & - & - & 9.5 & 4.8 & 7.1 & 2.4 & \\
& 2.4 & 7.1 & 4.8 & 2.4 & 7.2 & 4.8 & 2.4 & 7.2 & 9.5 & 2.4 & 2.4 & - & 9.5 & - & 4.8 & - & - & 2.4 & 4.8 \\
Fringilla montifringilla & 63.5 & 38.5 & 36.2 & 44.1 & 32.6 & 61.3 & 49.8 & 30.7 & 51.7 & 64.3 & 124 & 124 & 61.9 & 38.1 & 14.3 & 28.6 & 33.3 & 78.6 & \\
& 59.5 & 52.4 & 52.5 & 97.9 & 88.3 & 78.8 & 62.1 & 76.4 & 93.1 & 42.9 & 42.9 & 61.9 & 102 & 95.2 & 71.4 & 64.3 & 66.7 & 76.2 & 83.3 \\
Carduelis spinus & - & - & - & - & - & - & - & - & 1.9 & - & - & - & - & - & - & - & - & - & \\
& 2.4 & - & - & 4.8 & 7.2 & - & - & - & - & - & - & - & - & 2.4 & - & 4.8 & 2.4 & - & 2.4 \\
Carduelis flammea & 5.5 & 11.3 & 2.3 & 5.7 & 23.0 & 90.0 & 7.7 & 23.0 & 86.2 & 19.3 & 23.8 & 26.2 & 28.6 & 9.5 & 28.6 & 2.4 & 16.7 & 50.0 & \\
\multirow{3}{*}{ Pyrrhula pyrrhula } & 38.1 & 11.9 & 7.2 & 4.8 & 31.0 & 14.3 & - & 14.3 & 14.3 & 4.8 & - & 23.8 & 16.7 & 21.4 & 28.6 & 23.8 & 26.2 & 50.0 & 61.9 \\
& - & - & - & - & - & - & - & - & - & - & 2.4 & - & - & - & 2.4 & - & - & 2.4 & \\
Emberiza citrinella & - & - & - & 2.4 & - & - & - & 2.4 & - & - & - & - & - & - & - & 2.4 & - & 2.4 & 2.4 \\
& - & - & - & - & - & - & - & - & - & - & - & 2.4 & - & - & - & - & - & - & \\
Emberiza schoeniclus & - & - & - & - & - & - & - & - & - & - & - & - & - & - & - & - & - & - & - \\
& 33.1 & 31.7 & 24.9 & 34.5 & 28.7 & 21.1 & 19.2 & 13.4 & 17.2 & 17.7 & 26.2 & 21.4 & 26.2 & 19.0 & 19.0 & 14.3 & 19.0 & 19.0 & \\
& 31.0 & 21.4 & 11.9 & 11.9 & 21.5 & 21.5 & 26.3 & 31.0 & 21.5 & 28.6 & 23.8 & 9.5 & 9.5 & 14.3 & 14.3 & 19.0 & 26.2 & 14.3 & 21.4 \\
\hline Area surveyed. km2 & 0.36 & 0.44 & 0.44 & 0.52 & 0.52 & 0.52 & 0.52 & 0.52 & 0.52 & 0.62 & 0.42 & 0.42 & 0.42 & 0.42 & 0.42 & 0.42 & 0.42 & 0.42 & \\
& 0.42 & 0.42 & 0.42 & 0.42 & 0.42 & 0.42 & 0.42 & 0.42 & 0.42 & 0.42 & 0.42 & 0.42 & 0.42 & 0.42 & 0.42 & 0.42 & 0.42 & 0.42 & 0.42 \\
\hline
\end{tabular}

Appendix 3. The derived densities (approx. number of territories $/ \mathrm{km}^{2}$ ) of all passerine species (excl. Corvidae) which have been confirmed or potential breeders in the subalpine birch forest of the study area near Ammarnäs in 1963-1999.

Härledda tätheter (ungefär motsvarande antal revir $/ \mathrm{km}^{2}$ ) för alla tättingar (utom kråkfåglar), som varit konstaterade eller tänkbara häckare i fältarbetsområdets fjällbjörkskog nära Ammarnäs 1963-1999.

\begin{tabular}{|c|c|c|c|c|c|c|c|c|c|c|c|c|c|c|c|c|c|c|c|}
\hline Species & $\begin{array}{l}1963 \\
1981\end{array}$ & $\begin{array}{l}64 \\
82\end{array}$ & $\begin{array}{l}65 \\
83\end{array}$ & $\begin{array}{l}66 \\
84\end{array}$ & $\begin{array}{l}67 \\
85\end{array}$ & $\begin{array}{l}68 \\
86\end{array}$ & $\begin{array}{l}69 \\
87\end{array}$ & $\begin{array}{l}70 \\
88\end{array}$ & $\begin{array}{l}71 \\
89\end{array}$ & $\begin{array}{l}72 \\
90\end{array}$ & $\begin{array}{l}73 \\
91\end{array}$ & $\begin{array}{l}74 \\
92\end{array}$ & $\begin{array}{l}75 \\
93\end{array}$ & $\begin{array}{l}76 \\
94\end{array}$ & $\begin{array}{l}77 \\
95\end{array}$ & $\begin{array}{l}78 \\
96\end{array}$ & $\begin{array}{l}79 \\
97\end{array}$ & $\begin{array}{l}80 \\
98\end{array}$ & 99 \\
\hline \multirow[t]{2}{*}{ Anthus trivialis } & 13.9 & 25.8 & 18.8 & 11.6 & 11.8 & 8.3 & 6.8 & 9.6 & 6.5 & 7.4 & 12.1 & 11.0 & 9.3 & 12.5 & 8.3 & 11.6 & 6.2 & 10.3 & \\
\hline & 7.0 & 8.6 & 8.2 & 9.8 & 13.9 & 17.4 & 22.8 & 23.7 & 17.4 & 14.6 & 7.1 & 6.1 & 6.0 & 8.0 & 4.6 & 7.4 & 11.0 & 12.8 & 11.5 \\
\hline \multirow[t]{2}{*}{ Anthus pratensis } & - & 5.5 & 0.3 & - & 1.2 & 1.0 & 0.5 & 0.5 & - & - & 0.3 & 0.5 & 0.8 & 0.2 & 0.2 & 0.4 & 0.9 & 0.4 & \\
\hline & 0.9 & 1.3 & 0.6 & 0.4 & 0.7 & 0.7 & 2.0 & 7.1 & 8.3 & 6.6 & 4.9 & 1.3 & 4.3 & 6.9 & 4.7 & 4.7 & 3.2 & 3.4 & 0.8 \\
\hline \multirow[t]{2}{*}{ Motacilla flava } & 0.5 & - & - & - & - & 0.3 & 0.2 & - & 0.3 & 0.3 & 0.7 & 1.3 & 1.3 & 1.7 & 1.5 & 1.2 & 1.0 & 1.1 & \\
\hline & 1.1 & 1.4 & 1.5 & 1.6 & 3.0 & 1.0 & 2.7 & 6.4 & 3.9 & 3.4 & 1.3 & 1.5 & 1.8 & 4.2 & 3.3 & 4.4 & 4.7 & 3.7 & 1.7 \\
\hline \multirow[t]{2}{*}{ Motacilla alba } & - & - & - & - & - & - & - & - & - & 0.3 & - & 0.3 & 0.3 & 0.2 & 0.8 & 0.9 & 0.2 & - & \\
\hline & 0.3 & 0.2 & - & 0.6 & 0.6 & 0.2 & 0.6 & 0.8 & 1.5 & 0.3 & 0.7 & 0.4 & 0.4 & 0.7 & 0.4 & 1.0 & - & - & 0.8 \\
\hline \multirow[t]{2}{*}{ Cinclus cinclus } & - & - & - & - & - & - & 0.2 & 0.2 & 0.3 & 0.5 & 0.3 & - & 0.3 & 0.4 & - & 0.4 & - & 0.2 & \\
\hline & 0.2 & - & - & - & 0.3 & - & - & 0.3 & 0.3 & 0.2 & 0.4 & 0.2 & 0.3 & 0.3 & - & 0.2 & 1.3 & 0.4 & 0.3 \\
\hline \multirow[t]{2}{*}{ Troglodytes troglodytes } & - & - & - & - & 0.3 & - & - & - & - & - & - & 0.7 & - & - & 0.4 & - & - & - & \\
\hline & - & - & - & - & - & - & - & 0.6 & - & - & - & 0.2 & 1.0 & 0.3 & 0.6 & 1.2 & 0.3 & 0.7 & 0.6 \\
\hline \multirow[t]{2}{*}{ Prunella modularis } & 10.6 & 18.2 & 14.5 & 16.8 & 29.2 & 13.1 & 19.9 & 16.8 & 15.6 & 12.2 & 30.5 & 22.9 & 24.7 & 16.8 & 18.8 & 15.7 & 10.9 & 11.3 & \\
\hline & 23.4 & 18.9 & 7.7 & 6.6 & 10.4 & 11.0 & 15.8 & 18.3 & 22.2 & 16.1 & 13.4 & 9.8 & 12.0 & 19.6 & 21.5 & 15.6 & 13.0 & 14.6 & 11.2 \\
\hline \multirow[t]{2}{*}{ Erithacus rubecula } & - & 2.5 & - & 0.2 & - & - & - & - & - & - & - & 0.8 & 0.3 & - & - & - & - & - & \\
\hline & - & - & 0.2 & 0.1 & - & 6.8 & - & - & 0.3 & - & 0.2 & 0.2 & 0.2 & - & - & 0.2 & - & 1.2 & - \\
\hline \multirow[t]{2}{*}{ Luscinia svecica } & 3.8 & 3.8 & 4.3 & 4.6 & 20.3 & 10.6 & 7.6 & 6.5 & 10.2 & 5.8 & 21.5 & 7.6 & 12.6 & 13.8 & 15.7 & 10.4 & 7.9 & 4.9 & \\
\hline & 10.7 & 14.5 & 1.7 & 1.1 & 12.4 & 5.1 & 16.9 & 16.7 & 16.9 & 6.1 & 6.6 & 3.5 & 4.5 & 4.5 & 12.8 & 5.1 & 17.4 & 8.4 & 5.9 \\
\hline \multirow[t]{2}{*}{ Phoenicurus phoenicurus } & 27.9 & 15.6 & 14.5 & 4.4 & 10.3 & 5.0 & 5.4 & 3.8 & 11.1 & 6.0 & 10.5 & 8.5 & 5.3 & 6.8 & 4.0 & 7.3 & 2.5 & 9.1 & \\
\hline & 8.4 & 7.0 & 6.7 & 4.2 & 5.5 & 6.5 & 10.3 & 12.5 & 12.8 & 5.3 & 9.2 & 8.5 & 7.9 & 6.9 & 6.4 & 6.1 & 16.6 & 6.6 & 14.6 \\
\hline \multirow[t]{2}{*}{ Saxicola rubetra } & 2.4 & 2.5 & 0.5 & 0.2 & - & - & - & - & - & - & 0.7 & 0.3 & 1.5 & 0.4 & 1.0 & - & 0.9 & 0.4 & \\
\hline & 0.6 & 0.7 & 0.2 & 1.5 & - & 0.2 & 0.5 & 0.8 & 1.0 & 0.7 & 0.9 & 0.6 & - & 0.3 & 0.6 & - & 1.3 & - & - \\
\hline \multirow[t]{2}{*}{ Oenanthe oenanthe } & - & - & - & - & - & 0.3 & 0.3 & - & - & - & - & - & - & - & - & - & - & - & \\
\hline & - & - & - & - & 0.4 & - & - & - & - & - & - & - & - & 0.3 & - & - & - & 0.3 & 0.3 \\
\hline \multirow[t]{2}{*}{ Turdus torquatus } & - & - & - & - & 0.4 & - & - & 0.2 & 0.6 & 0.4 & 0.8 & 0.9 & - & - & 0.4 & - & - & - & \\
\hline & 0.9 & 0.2 & 0.2 & 0.4 & 1.0 & 0.9 & 0.9 & 0.6 & 1.4 & 0.2 & 1.2 & 0.3 & 1.1 & 0.9 & 1.0 & 0.7 & 1.3 & 1.3 & 0.6 \\
\hline \multirow[t]{2}{*}{ Turdus merula } & - & 0.8 & 0.3 & 0.5 & 0.9 & 0.3 & - & - & 0.6 & 0.5 & 0.3 & - & - & - & 0.2 & - & - & 0.4 & \\
\hline & - & 0.2 & 0.4 & 1.0 & 0.2 & 0.5 & 2.7 & 0.8 & 0.4 & - & - & 0.6 & 0.3 & - & - & - & - & 0.5 & 1.4 \\
\hline \multirow[t]{2}{*}{ Turdus pilaris } & 2.9 & 10.6 & 12.9 & 8.5 & 14.8 & 34.7 & 16.1 & 14.7 & 13.9 & 24.3 & 15.1 & 17.1 & 11.6 & 4.3 & 6.0 & 11.0 & 5.1 & 6.2 & \\
\hline & 5.6 & 6.9 & 6.6 & 4.8 & 17.0 & 7.1 & 16.5 & 20.0 & 26.4 & 14.3 & 15.3 & 8.5 & 9.4 & 18.9 & 21.7 & 16.0 & 31.6 & 24.0 & 20.2 \\
\hline \multirow[t]{2}{*}{ Turdus philomelos } & 11.5 & 15.2 & 12.5 & 11.9 & 15.0 & 10.6 & 9.9 & 7.9 & 9.1 & 7.2 & 9.8 & 9.3 & 8.3 & 5.5 & 6.6 & 6.3 & 3.6 & 3.7 & \\
\hline & 5.6 & 4.3 & 2.8 & 2.4 & 5.4 & 3.7 & 7.7 & 7.6 & 11.0 & 4.9 & 5.9 & 4.5 & 6.0 & 8.4 & 8.5 & 3.6 & 4.9 & 5.5 & 5.6 \\
\hline \multirow[t]{2}{*}{ Turdus iliacus } & 19.2 & 19.0 & 34.5 & 19.8 & 30.6 & 49.5 & 38.5 & 30.9 & 34.9 & 43.4 & 36.1 & 37.5 & 22.9 & 22.5 & 15.0 & 17.8 & 15.2 & 18.9 & \\
\hline & 32.6 & 23.8 & 18.0 & 19.2 & 32.2 & 21.7 & 35.7 & 41.7 & 37.2 & 20.8 & 27.3 & 16.8 & 24.8 & 30.2 & 29.1 & 29.6 & 32.8 & 32.0 & 37.1 \\
\hline
\end{tabular}


Appendix 3 continued

\begin{tabular}{|c|c|c|c|c|c|c|c|c|c|c|c|c|c|c|c|c|c|c|c|}
\hline \multirow[t]{2}{*}{ Species } & 1963 & 64 & 65 & 66 & 67 & 68 & 69 & 70 & 71 & 72 & 73 & 74 & 75 & 76 & 77 & 78 & 79 & 80 & \\
\hline & 1981 & 82 & 83 & 84 & 85 & 86 & 87 & 88 & 89 & 90 & 91 & 92 & 93 & 94 & 95 & 96 & 97 & 98 & 99 \\
\hline \multirow[t]{2}{*}{ Acrocephalus dumetorum } & - & - & - & - & - & - & - & - & - & - & - & - & - & - & - & - & - & - & \\
\hline & - & - & - & - & - & - & - & - & - & - & 0.2 & - & - & - & - & - & - & - & - \\
\hline \multirow[t]{2}{*}{ Hippolais icterina } & - & - & - & - & - & - & 0.2 & 0.2 & - & - & 0.7 & - & - & 0.4 & - & - & 0.2 & 1.1 & \\
\hline & 1.0 & 0.2 & 0.2 & 0.9 & 0.7 & 0.3 & - & 0.3 & 0.6 & 0.3 & 0.4 & 0.5 & 1.7 & 0.3 & 0.3 & 0.5 & - & 0.7 & - \\
\hline \multirow[t]{2}{*}{ Sylvia curruca } & - & 0.4 & 0.1 & - & - & - & - & 0.2 & - & - & - & - & - & - & - & - & - & - & \\
\hline & - & - & 0.2 & 0.3 & - & - & - & - & - & - & 0.3 & - & - & - & - & - & - & - & - \\
\hline \multirow[t]{2}{*}{ Sylvia borin } & 6.2 & 7.6 & 12.2 & 11.9 & 5.6 & 5.2 & 7.2 & 4.1 & 2.3 & 3.7 & 4.6 & 2.8 & 1.3 & 2.7 & 1.8 & 0.8 & 1.6 & 2.0 & \\
\hline & 2.0 & 0.9 & 0.7 & 2.9 & 0.4 & 4.5 & 3.0 & 2.3 & 2.1 & 2.0 & 1.4 & 2.6 & 1.4 & - & 0.6 & 1.0 & 0.8 & 1.2 & 0.3 \\
\hline \multirow[t]{2}{*}{ Sylvia atricapilla } & - & - & - & - & - & - & - & 0.2 & - & - & 1.0 & 0.5 & - & - & - & - & - & 0.8 & \\
\hline & - & 0.2 & 0.2 & 1.0 & 0.4 & - & - & - & - & - & 0.2 & - & 0.2 & - & 0.3 & - & 0.6 & - & 0.6 \\
\hline \multirow[t]{2}{*}{ Phylloscopus trochiloides } & - & - & - & - & - & - & - & - & - & - & - & - & - & - & - & - & - & - & \\
\hline & - & - & - & - & - & - & - & - & - & - & - & 0.2 & - & - & - & - & - & - & - \\
\hline \multirow[t]{2}{*}{ Phylloscopus borealis } & - & - & - & - & - & - & - & - & - & - & 0.3 & - & - & - & - & - & - & - & \\
\hline & - & - & - & - & - & - & - & - & - & - & - & - & - & 0.3 & - & 0.2 & - & - & - \\
\hline \multirow[t]{2}{*}{ Phylloscopus collybita } & - & - & - & - & - & - & - & - & - & - & - & - & - & - & - & - & - & - & \\
\hline & - & - & - & 0.3 & - & - & - & - & - & - & - & 0.2 & - & - & - & - & 0.9 & - & - \\
\hline Phylloscopus sibilatrix & 0.5 & 1.3 & - & - & - & - & - & - & - & - & - & 0.2 & - & - & - & - & - & 0.3 & \\
\hline & - & - & - & 1.1 & 0.9 & 1.0 & 0.3 & 0.3 & - & - & - & 0.6 & 0.3 & - & 0.3 & - & 1.3 & - & 0.3 \\
\hline Phylloscopus trochilus & 154 & 206 & 208 & 160 & 175 & 162 & 147 & 158 & 169 & 160 & 182 & 151 & 144 & 130 & 108 & 123 & 92 & 104 & \\
\hline & 108 & 134 & 105 & 88 & 171 & 142 & 181 & 193 & 212 & 156 & 116 & 157 & 229 & 207 & 178 & 188 & 194 & 177 & 177 \\
\hline Muscicapa striata & 0.5 & 0.8 & 1.4 & 1.4 & 1.6 & 2.3 & 1.9 & 1.4 & 3.4 & 1.6 & 2.5 & 2.6 & 0.8 & 1.5 & 0.7 & 1.2 & 1.1 & 2.8 & \\
\hline & 3.1 & 2.2 & 2.2 & 2.1 & 3.0 & 3.0 & 3.3 & 6.4 & 7.9 & 5.3 & 9.0 & 3.6 & 3.9 & 5.9 & 7.3 & 3.3 & 4.3 & 2.7 & 4.2 \\
\hline Ficedula hypoleuca & 22.1 & 14.4 & 14.3 & 4.1 & 12.0 & 8.4 & 13.0 & 13.2 & 16.7 & 10.1 & 7.7 & 9.8 & 10.1 & 7.5 & 8.9 & 4.1 & 3.2 & 2.4 & \\
\hline & 4.0 & 5.6 & 2.6 & 7.8 & 17.1 & 5.0 & 7.6 & 11.8 & 17.4 & 5.3 & 8.2 & 3.4 & 2.9 & 4.0 & 2.1 & 3.9 & 6.1 & 5.9 & 3.9 \\
\hline Parus montanus & 4.8 & 3.0 & 9.2 & 2.6 & 3.0 & 3.5 & 2.8 & 2.4 & 3.9 & 2.9 & 1.2 & 3.3 & 0.8 & 1.7 & 2.5 & 1.6 & 1.7 & 1.5 & \\
\hline & 3.6 & 2.6 & 0.7 & 0.8 & 5.6 & 1.9 & 3.3 & 2.2 & 1.3 & 1.4 & 0.9 & 0.5 & 1.9 & 2.6 & 3.5 & 2.5 & 1.8 & 1.8 & 0.6 \\
\hline Parus cinctus & - & - & - & - & - & - & - & - & - & - & - & - & - & - & - & - & - & - & \\
\hline & 0.3 & - & - & - & 0.6 & - & 0.6 & - & - & - & 0.3 & - & 0.2 & 0.3 & 0.3 & 0.7 & - & - & - \\
\hline Parus major & 1.4 & 0.4 & 1.7 & 0.5 & 1.5 & 1.0 & 0.9 & 1.3 & 0.3 & 0.5 & 1.0 & 1.2 & 1.8 & 0.2 & 1.2 & 0.7 & 0.8 & 0.6 & \\
\hline & 1.2 & 0.8 & 0.6 & 1.3 & 2.9 & 0.9 & 1.7 & 2.1 & 0.7 & 0.9 & 0.8 & 0.4 & 1.5 & 2.0 & 1.4 & 2.0 & 3.2 & 2.9 & 1.4 \\
\hline Certhia familaris & - & 0.4 & 0.3 & - & - & - & - & - & - & - & - & - & - & - & - & 0.2 & - & - & \\
\hline & - & - & - & - & - & - & - & - & - & - & - & - & - & - & - & - & - & - & - \\
\hline Lanius excubitor & - & - & - & - & - & - & - & - & - & - & - & 0.3 & - & - & - & 0.2 & - & - & \\
\hline & - & - & - & - & - & - & - & - & - & - & - & - & - & - & - & - & - & - & - \\
\hline Fringilla coelebs & 2.4 & 3.4 & 7.7 & 3.1 & 2.2 & 1.2 & 0.8 & 0.9 & 1.5 & 1.3 & 2.5 & 4.9 & 2.3 & 0.2 & 2.7 & 1.5 & 1.3 & 2.1 & \\
\hline & 2.0 & 1.1 & 0.7 & 1.8 & 3.2 & 5.4 & 5.2 & 6.8 & 4.2 & 0.6 & 0.9 & 0.7 & 2.6 & 1.8 & 1.1 & 0.9 & 2.0 & 4.8 & 5.6 \\
\hline Fringilla montifringilla & 76.9 & 45.7 & 49.8 & 43.0 & 52.6 & 83.3 & 51.8 & 43.8 & 73.3 & 89.1 & 142 & 153 & 71.5 & 51.1 & 36.2 & 44.1 & 38.4 & 80.0 & \\
\hline & 72.9 & 52.3 & 49.7 & 112 & 104 & 100 & 76.0 & 86.6 & 110 & 62.5 & 54.6 & 78.9 & 126 & 101 & 80.3 & 61.6 & 69.9 & 73.7 & 76.1 \\
\hline Carduelis chloris & - & - & - & - & - & - & - & - & - & - & - & - & - & - & - & - & - & - & \\
\hline & - & - & - & - & - & - & 0.2 & - & - & - & - & - & 0.2 & - & - & - & - & 0.8 & 0.6 \\
\hline Carduelis spinus & 1.4 & 0.8 & 2.1 & 0.3 & 0.6 & 0.7 & 0.8 & 0.5 & 3.3 & 2.1 & - & 2.9 & - & - & 0.8 & 0.4 & 0.6 & 0.9 & \\
\hline & 3.2 & 0.2 & 0.2 & 2.8 & 10.5 & 0.9 & 4.1 & 2.0 & 1.5 & 7.0 & 1.9 & 0.9 & 3.8 & 12.0 & 1.0 & 11.4 & 6.6 & 6.2 & 3.9 \\
\hline Carduelis flammea & 4.3 & 11.8 & 5.5 & 9.1 & 16.2 & 82.5 & 6.7 & 14.4 & 78.5 & 15.8 & 25.7 & 22.3 & 22.9 & 20.8 & 36.0 & 1.7 & 27.6 & 24.1 & \\
\hline & 50.2 & 32.3 & 10.6 & 8.7 & 17.7 & 8.0 & 3.7 & 35.7 & 20.2 & 26.4 & 2.1 & 20.1 & 31.8 & 26.3 & 15.2 & 23.3 & 17.6 & 33.0 & 41.0 \\
\hline Carduelis hornemanni & - & - & - & - & - & - & - & - & - & - & - & - & - & - & - & - & 0.2 & - & \\
\hline & - & - & - & - & - & - & - & 0.3 & 0.5 & 0.2 & - & 0.3 & 0.4 & 0.5 & - & 0.2 & - & - & - \\
\hline Carpodacus erythrinus & - & - & - & - & - & - & - & - & - & - & - & - & - & - & - & - & - & - & \\
\hline & - & - & - & 0.2 & - & - & - & - & 0.3 & - & - & - & - & - & - & - & - & - & - \\
\hline Pyrrhula pyrrhula & - & 0.4 & 1.2 & 1.1 & - & - & 0.8 & 0.2 & 0.5 & - & 0.8 & 0.9 & 0.5 & 0.7 & 0.8 & 1.0 & 0.8 & 0.8 & \\
\hline & 2.6 & 0.8 & 0.2 & 0.9 & 1.0 & 0.6 & 4.8 & 0.6 & 0.6 & 1.0 & 0.6 & - & 1.6 & 0.4 & 2.4 & 4.0 & 0.9 & 3.9 & 1.4 \\
\hline Emberiza citrinella & - & - & - & 0.2 & - & - & - & 0.2 & - & - & 0.7 & 0.7 & - & - & 0.6 & - & - & - & \\
\hline & - & - & - & 0.1 & 0.3 & - & - & - & - & - & - & 0.2 & - & - & 0.3 & - & - & - & 0.3 \\
\hline Emberiza hortulana & - & 0.4 & - & - & - & - & - & - & - & - & - & 0.2 & - & - & - & - & - & - & \\
\hline & - & - & - & - & - & - & - & - & - & - & - & - & - & - & - & - & - & - & - \\
\hline Emberiza pusilla & - & - & - & - & - & - & - & - & - & - & - & - & - & - & - & - & - & - & \\
\hline & - & - & - & - & - & - & - & - & - & - & 0.2 & 0.2 & - & 0.3 & - & - & - & - & - \\
\hline Emberiza schoeniclus & 13.9 & 27.1 & 15.6 & 18.2 & 24.2 & 15.5 & 23.1 & 17.5 & 13.1 & 12.4 & 23.8 & 23.6 & 24.9 & 15.1 & 25.9 & 21.1 & 12.4 & 14.0 & \\
\hline & 20.2 & 23.3 & 10.9 & 8.4 & 23.2 & 15.8 & 19.5 & 43.9 & 20.6 & 15.1 & 19.0 & 11.5 & 12.4 & 16.2 & 21.5 & 14.7 & 24.4 & 19.7 & 15.7 \\
\hline
\end{tabular}


Appendix 4. Mean temperature $\left({ }^{\circ} \mathrm{C}\right)$ in Ammarnäs for May, June and July 1963-1999. Medeltemperaturen ( ${ }^{\circ}$ ) i Ammarnäs för maj, juni och juli 1963-1999.

\begin{tabular}{|c|c|c|c|c|c|c|c|}
\hline \multirow[t]{2}{*}{$\begin{array}{l}\text { Year } \\
\text { Ar }\end{array}$} & \multirow[b]{2}{*}{ May } & \multicolumn{2}{|c|}{$\begin{array}{l}\text { Mean temperature } \\
\text { Medeltemperatur }\end{array}$} & \multirow[t]{2}{*}{$\begin{array}{l}\text { Year } \\
\text { Ar }\end{array}$} & \multicolumn{3}{|c|}{$\begin{array}{l}\text { Mean temperature } \\
\text { Medeltemperatur }\end{array}$} \\
\hline & & June & July & & May & June & July \\
\hline 1963 & 8.3 & 9.9 & 11.3 & 1982 & 3.9 & 7.4 & 12.0 \\
\hline 1964 & 5.6 & 8.0 & 11.0 & 1983 & 6.2 & 9.1 & 12.1 \\
\hline 1965 & 2.6 & 10.2 & 10.6 & 1984 & 8.4 & 10.1 & 11.8 \\
\hline 1966 & 3.5 & 13.3 & 12.1 & 1985 & 3.3 & 10.9 & 13.0 \\
\hline 1967 & 3.9 & 9.1 & 11.5 & 1986 & 6.2 & 12.8 & 12.5 \\
\hline 1968 & 2.0 & 10.3 & 11.2 & 1987 & 3.7 & 9.7 & 11.3 \\
\hline 1969 & 3.1 & 12.1 & 12.1 & 1988 & 4.9 & 11.9 & 14.4 \\
\hline 1970 & 5.0 & 13.6 & 12.4 & 1989 & 5.0 & 9.9 & 10.9 \\
\hline 1971 & 4.0 & 9.7 & 11.5 & 1990 & 4.8 & 11.1 & 12.8 \\
\hline 1972 & 4.3 & 12.2 & 14.1 & 1991 & 3.7 & 8.9 & 13.8 \\
\hline 1973 & 4.4 & 10.4 & 15.5 & 1992 & 6.5 & 10.6 & 10.4 \\
\hline 1974 & 5.9 & 11.4 & 12.0 & 1993 & 4.0 & 7.8 & 12.4 \\
\hline 1975 & 5.0 & 7.8 & 11.3 & 1994 & 4.2 & 8.0 & 13.7 \\
\hline 1976 & 6.0 & 9.6 & 12.0 & 1995 & 2.3 & 9.6 & 11.1 \\
\hline 1977 & 2.9 & 8.3 & 12.0 & 1996 & 3.4 & 9.2 & 11.9 \\
\hline 1978 & 3.6 & 11.0 & 13.1 & 1997 & 3.5 & 11.4 & 15.0 \\
\hline 1979 & 4.1 & 11.2 & 13.3 & 1998 & 3.2 & 9.4 & 13.2 \\
\hline 1980 & 4.9 & 13.0 & 14.2 & 1999 & 0.8 & 11.1 & 12.2 \\
\hline 1981 & 6.1 & 8.0 & 12.4 & & & & \\
\hline
\end{tabular}

